Florida International University FIU Digital Commons

5-24-2013

\title{
The Mediating Effect of Innovation on the Relationship between Corporate Reputation and Performance in U.S. Firms
}

Marcelo J. Alvarado-Vargas

Florida International University, malva043@fiu.edu

DOI: $10.25148 /$ etd.FI13080721

Follow this and additional works at: https://digitalcommons.fiu.edu/etd

Part of the International Business Commons, Strategic Management Policy Commons, and the Technology and Innovation Commons

\section{Recommended Citation}

Alvarado-Vargas, Marcelo J., "The Mediating Effect of Innovation on the Relationship between Corporate Reputation and Performance in U.S. Firms" (2013). FIU Electronic Theses and Dissertations. 927.

https://digitalcommons.fiu.edu/etd/927 


\title{
FLORIDA INTERNATIONAL UNIVERSITY
}

Miami, Florida

\section{THE MEDIATING EFFECT OF INNOVATION ON THE RELATIONSHIP} BETWEEN CORPORATE REPUTATION AND PERFORMANCE IN U.S. FIRMS

A dissertation submitted in partial fulfillment of

\author{
the requirements for the degree of \\ DOCTOR OF PHILOSOPHY \\ in \\ BUSINESS ADMINISTRATION
}

by

Marcelo J. Alvarado-Vargas 
To: Dean David R. Klock

College of Business Administration

This dissertation, written by Marcelo J. Alvarado-Vargas, and entitled The Mediating Effect of Innovation on the Relationship between Corporate Reputation and Performance in U.S. Firms, having been approved in respect to style and intellectual content, is referred to you for judgment.

We have read this dissertation and recommend that it be approved.

Sumit K. Kundu

Ronaldo Parente

Nathan Hiller

Weidong Xia

William Newburry, Major Professor

Date of Defense: May 24, 2013

The dissertation of Marcelo J. Alvarado-Vargas is approved.

Dean David R. Klock

College of Business Administration

Dean Lakshmi N. Reddi

University Graduate School

Florida International University, 2013 


\section{DEDICATION}

I dedicate this work to my beloved family, Enrique, Virginia, Leina, and Cecilia. You are my world. There is no distance that can separate us. Siempre los tengo presente en mis pensamientos.

Si aún puedes ser mejor de lo que eres, es evidente que aún no eres tan bueno

como debes - San Agustín 


\section{ACKNOWLEDGMENTS}

I would like to thank the members of my committee for their support and patience. A special gratitude to the chair of the Department of Management and International

Business, Dr. Kroeck, for his continuous support and guidance. Dr. Kundu offered excellent advices in relationship to the $\mathrm{PhD}$ program and future academic career, thank you. Finally, I would like to express gratitude to my major professor, Dr. Newburry, for his guidance in this academic journey. 


\begin{abstract}
OF THE DISSERTATION
THE MEDIATING EFFECT OF INNOVATION ON THE RELATIONSHIP BETWEEN CORPORATE REPUTATION AND PERFORMANCE IN U.S. FIRMS by
\end{abstract}

Marcelo J. Alvarado-Vargas

Florida International University, 2013

Miami, Florida

\title{
Professor William Newburry, Major Professor
}

In recent years, corporate reputation has gained the attention of many scholars in the strategic management and related fields. There is a general consensus that higher corporate reputation is positively related to firm success or performance. However, the link is not always straightforward; as a result, it calls for researchers to dedicate their efforts to investigate the causes and effects of firm reputation and how it is related to performance. In this doctoral dissertation, innovation is suggested as a mediating variable in this relationship. Innovation is a critical factor for firm success and survival. Highly reputed firms are in a more advantageous position to attract critical resources for innovation such as human and financial capital. These firms face constant pressure from external stakeholders, e.g. the general public, or customers, to achieve and remain at high levels of innovativeness. As a result, firms are in constant search, internally or externally, for new technologies expanding their knowledge base. Consequently, these firms engage in firms acquisitions. In the dissertation, the author assesses the effects of domestic versus international acquisitions as well as related versus unrelated acquisitions on the level of innovativeness and performance. 
Building upon an established measure of firm-level degree of internationalization (DOI), the dissertation proposes a more detailed and enhanced measure for the firm's DOI. It is modeled as an interaction effect between corporate reputation and resources for innovation. More specifically, firms with higher levels of internationalization will have access to resources for innovation, i.e. human and financial capital, at a global scale. Additionally, the distance between firms and higher education institutions, i.e. universities, is considered as another interaction effect for the human capital attraction. The dissertation is built on two theoretical frameworks, the resource-based view of the firm and institutional theory. It studies 211 U.S. firms using a longitudinal panel data structure from 2006 to 2012. It utilizes a linear dynamic panel data estimation methodology for its hypotheses analyses. Results confirm the hypotheses proposed in the study. 


\section{TABLE OF CONTENTS}

CHAPTER

PAGE

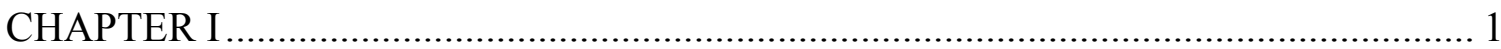

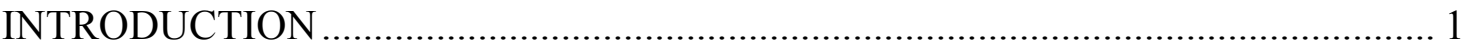

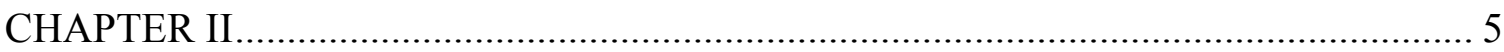

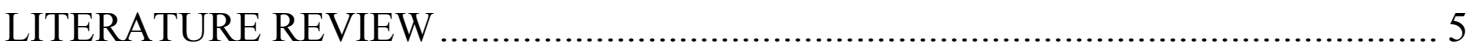

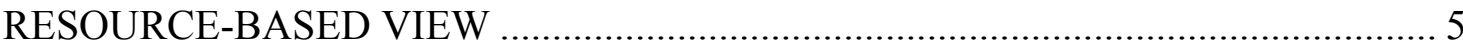

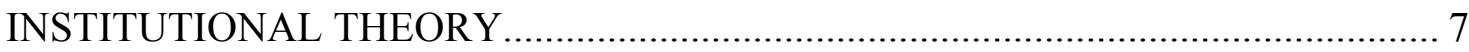

INTERNATIONALIZATION THEORY AND DEGREE OF

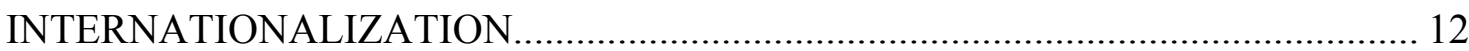

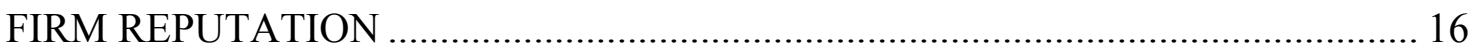

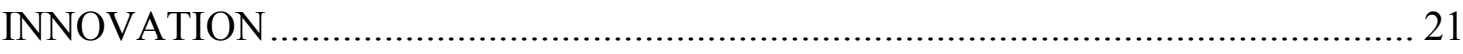

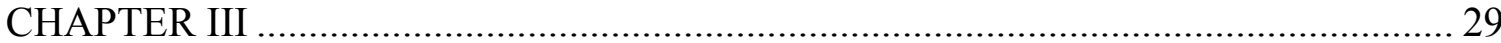

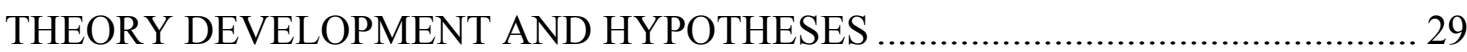

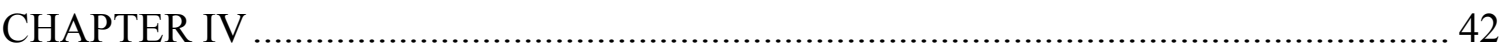

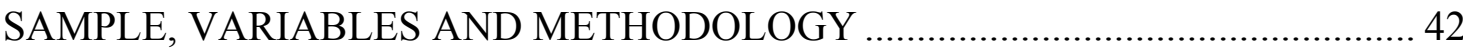

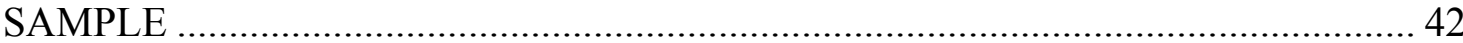

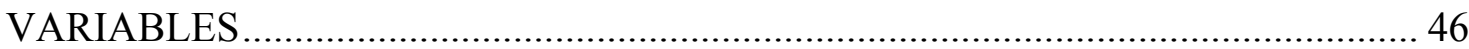

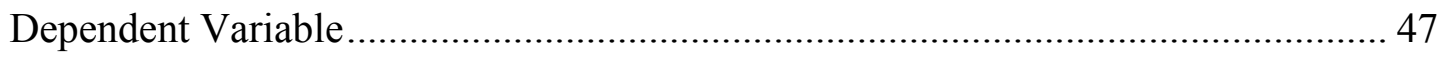

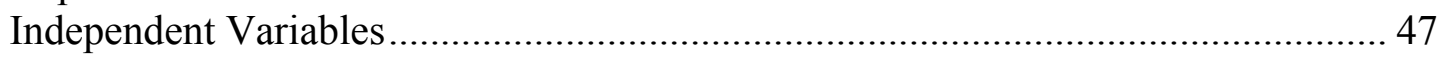

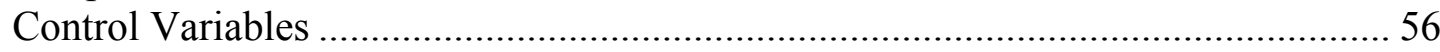

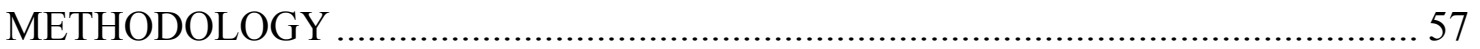

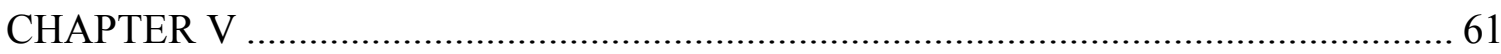

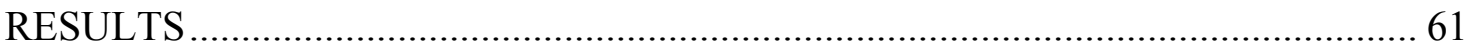

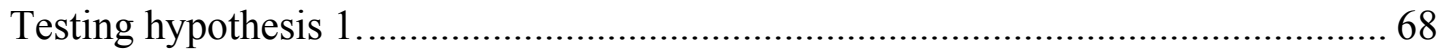

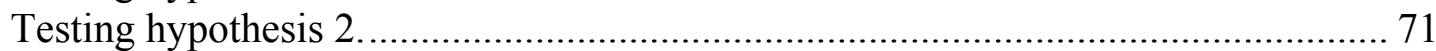

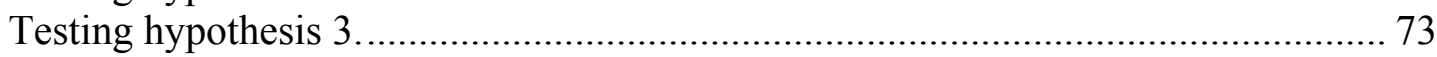

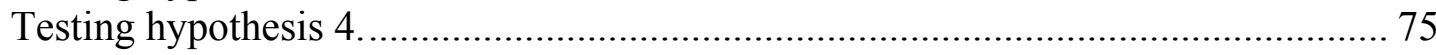

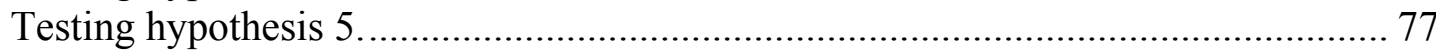

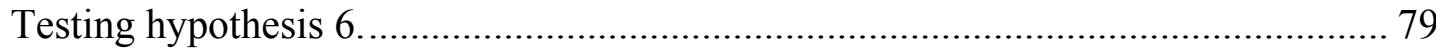

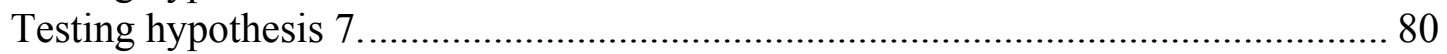

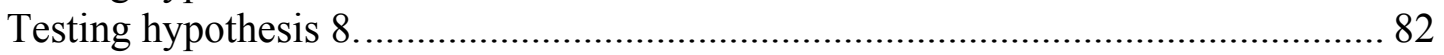

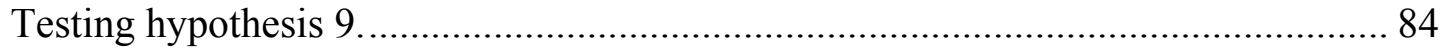

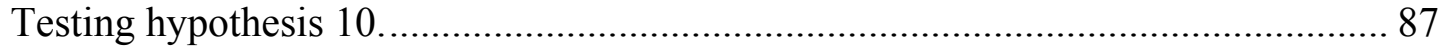

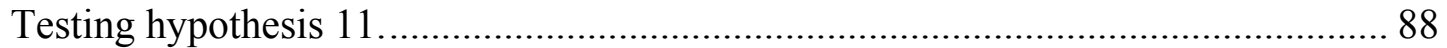

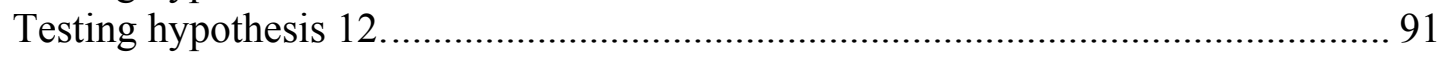

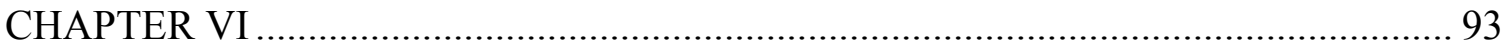

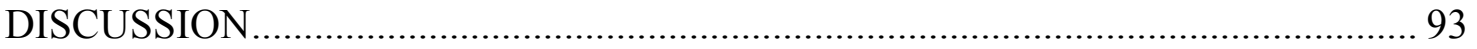




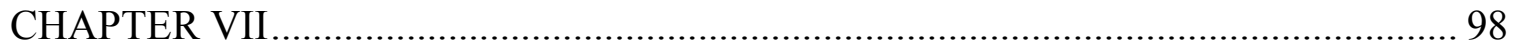
CONCLUSIONS, LIMITATIONS, FUTURE RESEARCH, AND RELEVANCE FOR

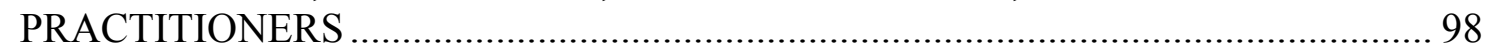

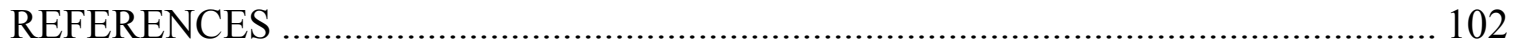

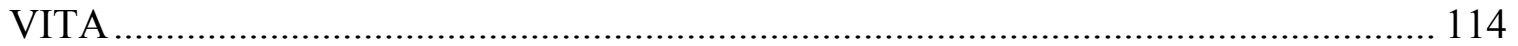




\section{LIST OF TABLES}

TABLE

PAGE

Table 1. Different Types of Resources. ...................................................................... 5

Table 2. Distribution of firms per SIC division. .................................................... 44

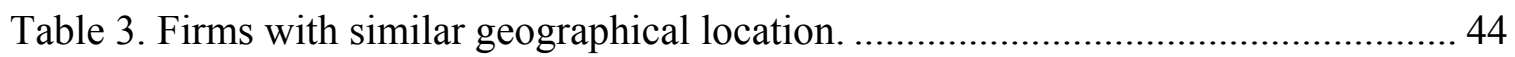

Table 4. List of selected variables and their roles in the dissertation ........................... 46

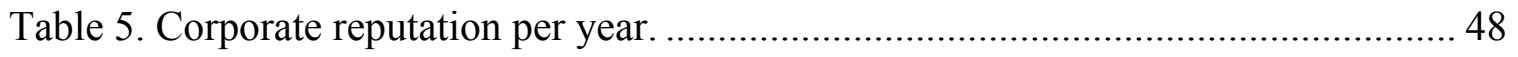

Table 6. Descriptive statistics of the overall rank per year.......................................... 49

Table 7. Number of firms per year per rank-industry by Fortune classification ............. 49

Table 8. Summary of firms per industry division per year by SIC classification............ 50

Table 9. Descriptive statistics of DOIs and correlation matrix.................................. 51

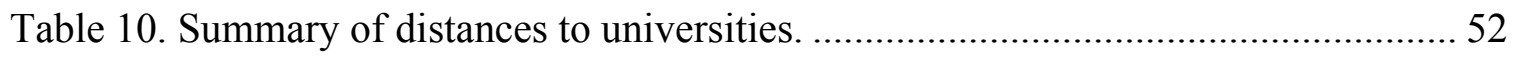

Table 11. Descriptive statistics of the number of employees per year. .......................... 52

Table 12. Descriptive statistics of short- and long-term debt per year. ......................... 53

Table 13. Descriptive statistics for knowledge/technology access ............................... 54

Table 14. Descriptive statistics for innovation capabilities. ..................................... 55

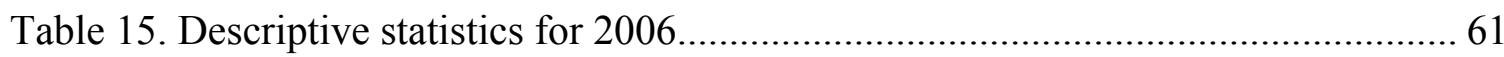

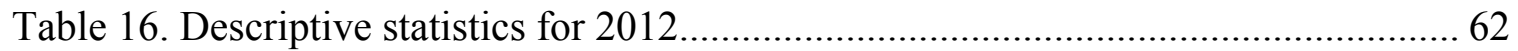

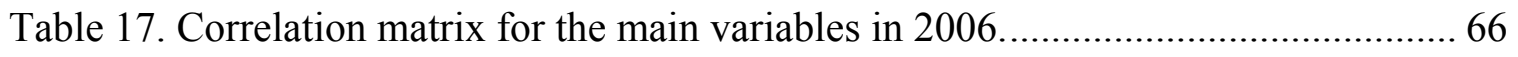

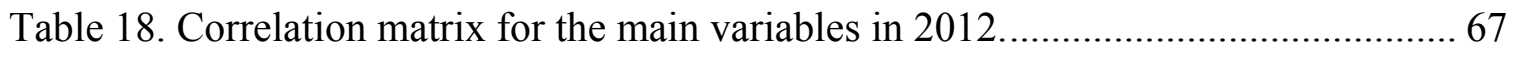




\section{LIST OF FIGURES}

FIGURE

PAGE

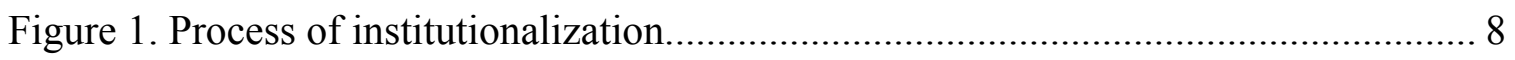

Figure 2. Breadth and depth of international operations......................................... 16

Figure 3. Mechanisms to pursue technological change. ............................................. 28

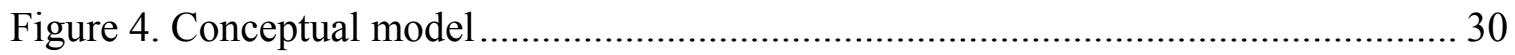

Figure 5. Firms with similar geographical location in the US ................................ 45

Figure 6. Lags for the linear dynamic panel data methodology ................................. 58

Figure 7. Structure of a basic mediating effect. ...................................................... 59

Figure 8. Box plot for reputation scores per year. ................................................ 64

Figure 9. Box plot for degree of internationalization (FSTS) per year........................... 64

Figure 10. Box plot for sales growth per year. ................................................. 65

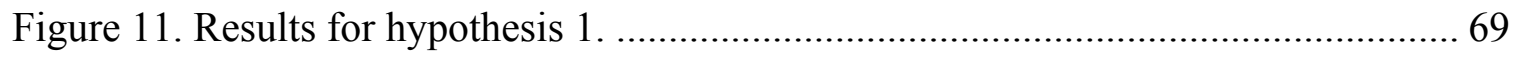

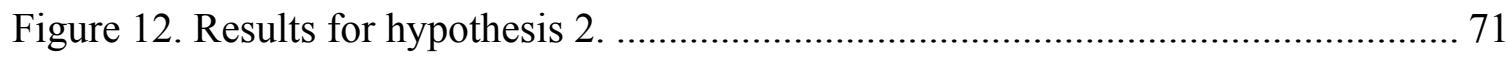

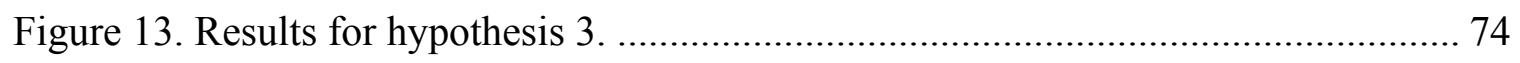

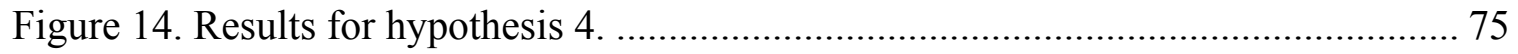

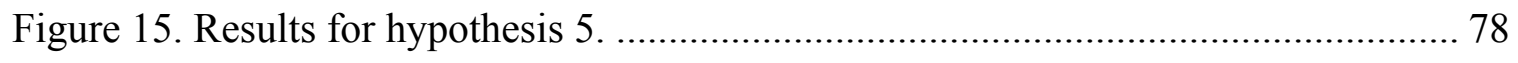

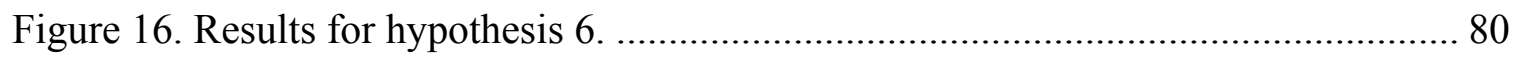

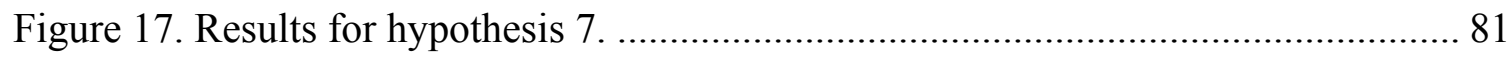

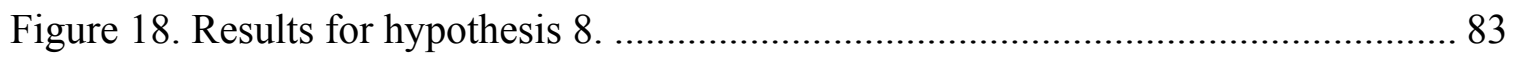

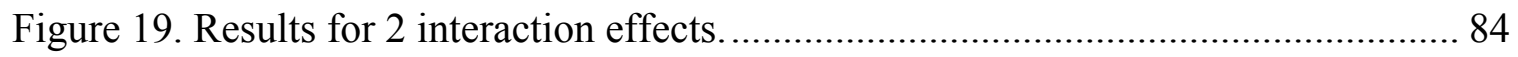

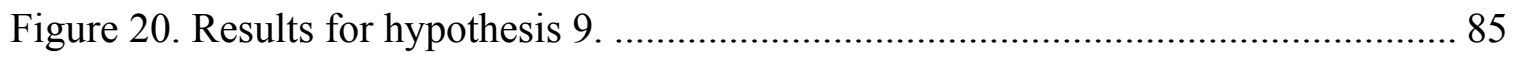

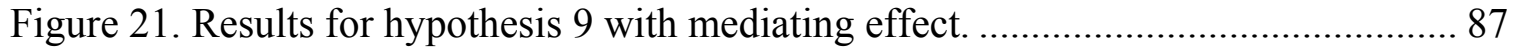




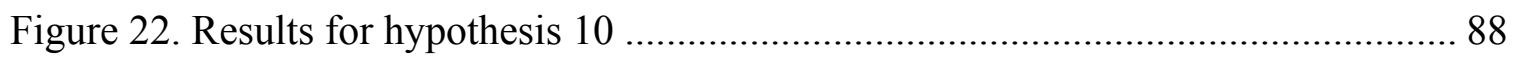

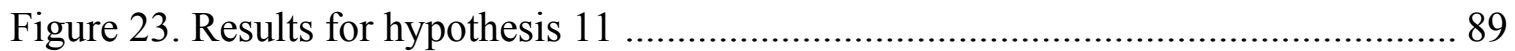

Figure 24. Results for hypothesis 11 with mediating effect. ..................................... 90

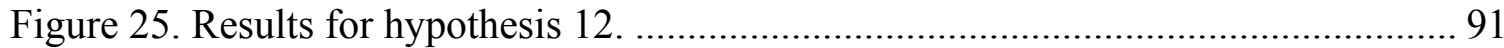




\section{CHAPTER I}

\section{INTRODUCTION}

In recent years, firm reputation has gained the attention of many scholars (e.g. Berens and van Riel, 2004; Deephouse, 2000; Deephouse and Carter, 2005; Deephouse, Li and Newburry, 2009; Fombrun and Shanley, 1990; Gardberg, 2006); it refers to the perceptions that different stakeholders have about a firm (Rindova, Williamson, Petkova and Sever, 2005). Firm reputation has been regarded as an intangible asset or resource, which can be valuable, rare, inimitable, and non-substitutable (Barney, 1991) for the firm. In line with the Resource-Based View (RBV), competitive advantages can be developed with resources with those characteristics. Other scholars regard firm reputation as a source of profits (Hall, 1992; Rindova et al., 2005) and value creation (Roberts and Dowling, 2002). Highly reputed firms can take advantage of their reputations and charge extra premiums for their products and/or services because they are perceived as better ones in the market (Klein and Leffler, 1981; Rindova et al., 2005). There is a general consensus among scholars and practitioners that a good firm reputation is positively related to firm success (Berens and van Riel, 2004; Brown, 1998; Fombrun, 1996; Newburry, 2010). However, the link is not always straightforward. Also, it is important to note that building a positive firm reputation is a slow cumulative process, but it takes only a few firm accidents, or negative actions to damage it, or to significantly decrease it; for example, the recall of Toyota's cars in 2009-2010, the BP deepwater oil spill in 2010, or the recall of cars by Toyota, Honda, and Nissan in 2013. Therefore, firm reputation needs to be central to corporate strategy research. 
As mentioned previously, the linkage between firm reputation and performance is not clear and straightforward; as a result, it calls for scholars to dedicate their efforts to investigate the causes and effects of firm reputation and how it is related to performance. For this doctoral dissertation, innovation is suggested as a mediating variable between firm reputation and performance. According to Schumpeter (1942; 2008), the strategic stimulus to economic development is innovation; firms that do not innovate may have a darker future compared to those firms that have innovation as part of their strategic competencies. Therefore, innovation is a critical factor for firm success or performance. There are many determinants for innovation; for example, firm size, market structure, profitability, and firm growth (Bhattacharya and Bloch, 2004); however, in this doctoral dissertation, the role of corporate reputation as a determinant of innovation will be explored, along with its subsequent impact on firm performance. Previous studies have addressed the linkages separately; in other words, the relationship between corporate reputation and performance, or the relationship between innovation and performance; however, there is no study attempting the linkage between these two research streams. This dissertation's main objective is to contribute and fill this gap; thus, the main contribution of this doctoral dissertation is to study a model in which both relationships are considered together through a mediation relationship.

In addition, the dissertation will analyze the isolated mechanisms which facilitate the increment of firm innovation capability derived from a high firm reputation. More specifically, critical resources for innovation such as human capital, financial capital, and access to knowledge and new technologies are increased by higher firm reputation. These resources are, then, antecedents for an increment of firm innovation capability. 
The dissertation attempts to contribute to the strategic management field, but also to the international business literature by proposing a new measure for the firm degree of internationalization (DOI). The proposed DOI includes the breadth and depth of the firm's international operations as experts in the field called for researchers to contribute to the topic (Thomas and Eden, 2004; Kafouros, Buckley and Clegg, 2012). This proposed DOI measure is utilized as an interaction variable in the reputation-innovation relationship; more specifically, the attraction of critical resources for innovation, i.e. human and financial capital, and knowledge, is stronger for firms with higher levels of internationalization as they are able to leverage the attraction of such resources from global sources. Results confirm the existence of the interaction effects.

The dissertation also studies the influence of geographical proximity to higher education institutions, i.e. universities. The geographical proximity to top ranked universities is considered to have an interaction effect on the attraction of human capital for innovation.

The dissertation dataset structure is longitudinal panel data for 211 US firms from 2006 to 2012. Thus, all the hypotheses testing were estimated by utilizing the ArellanoBond (Arellano and Bond, 1991) dynamic linear panel data methodology which is an appropriate methodology for longitudinal panel datasets with several panels (firms) and few periods of time.

The rest of the dissertation is structured in six chapters. In Chapter II, relevant theories to the dissertation are outlined. Chapter III elucidates the theory development and hypotheses formulations for the dissertation. Next, chapter IV explains the methodology, sample and variables used in the dissertation. Chapter V provides results 
obtained from estimating different models. Finally, chapters VI and VII provide insights for discussion, conclusions, limitations, future research and relevance for practitioners. 


\section{CHAPTER II}

\section{LITERATURE REVIEW}

\section{RESOURCE-BASED VIEW}

One of the theoretical frameworks for this dissertation is the Resource-Based View (RBV) of the firm (Barney, 1991; Rumelt, 1984; Wernelfelt, 1984). This theory states that firms are capable of creating competitive advantages in the marketplace from their internal resources (e.g., financial capital, physical capital, human capital, and organizational capital). Some examples of these resources are tangible and intangible assets, capabilities, knowledge, competencies, organizational processes, firm attributes, information, etc. See table 1 below to review some examples in the literature about different types of resources.

Table 1. Different Types of Resources.

\begin{tabular}{|c|c|}
\hline Article & Resource Type \\
\hline Barney, 1991 & $\begin{array}{l}\text { - Physical: plant and equipment, technology } \\
\text { - Organizational: information systems, } \\
\text { accounting systems. } \\
\text { - Human: skills, training, experience. }\end{array}$ \\
\hline $\begin{array}{l}\text { Cuervo-Cazurra, } \\
\text { Maloney, and } \\
\text { Manrakhan, } 2007\end{array}$ & $\begin{array}{l}\text { - Advantageous: if generates rents for the } \\
\text { firm. } \\
\text { - Disadvantageous: core rigidities } \\
\text { - Complementary: provides neither } \\
\text { advantages nor disadvantages for the firm. }\end{array}$ \\
\hline Grant, 1991 & $\begin{array}{l}\text { - Financial: free cash flow, ability to obtain } \\
\text { financial resources. } \\
\text { - Technological: know-how, patents. } \\
\text { - Intangible: brand, reputation. }\end{array}$ \\
\hline Wernerfelt, 1984 & $\begin{array}{l}\text { - Tangible: financial assets, production } \\
\text { assets. } \\
\text { - Intangible: networks, know-how, } \\
\text { reputation, patents, organizational culture. }\end{array}$ \\
\hline
\end{tabular}


The effective and efficient management of these resources by the firm provides a competitive advantage over a firm's competitors (Barney, 1991) and firm growth (Penrose, 1959).

In her book, Penrose's objective was to understand the organizational process through which firms achieve growth and the limitations of it. She argued that firms should be analyzed first as an administrative framework that links and coordinates different interactions between people and second that firms need to be analyzed as a bundle of productive resources. The nature of the resources and their management is heterogeneous; in other words, they vary significantly from one firm to another. Firms are fundamentally heterogeneous even if they are in the same industry; as a result, we find firms with different characteristics and competitive advantages due to resource heterogeneity, which is one of the two assumptions for RBV. The other assumption is resource immobility, which means that some resources are expensive to copy, scarce, or not for sale. Altogether, if resources meet the assumptions, they are potential sources of competitive advantage.

Barney (1991) suggests a framework called VRIO to identify resources which are potential sources of competitive advantage. This framework is structured in questions about the firms' business activities: the question of value, the question of rarity, the question of imitability, and the question of organization. In the first question, firms need to ask whether the resource being examined enables the firm to respond to environmental threats or opportunities; in the second, they need to know how many other firms may have access or already possess the same resource. In the question related to imitability, firms need to know whether firms without the resource under examination face a cost 
disadvantage in obtaining it compared to firms that already possess it. In other words, they need to know if firms without the resource can obtain it easily and cheaply. Finally, the firm needs to assess the question of whether the current organizational schema allows it to exploit the full competitive potential of the resource under examination. Research suggests that companies possessing valuable, rare, inimitable, and non-substitutable resources are more likely to generate a sustainable competitive advantage (Amit and Schoemaker, 1993; Barney, 1991; Grant, 1991; Peteraf, 1993; Wernerfelt, 1984).

In this dissertation, corporate reputation is considered an intangible asset (or resource) which provides sustainable competitive advantage to firms (Rindova, Yeow, Martins and Faraj, 2012). In other words, it is valuable, rare, cannot be easily imitated, and it is non-transferable or non-substitutable because the reputation for one company remains with it. In addition, innovation capability is also considered a source for competitive advantage in firms. In fact, innovation capability occupies a central role in this research study because the study analyzes the mediating effect of innovation (capability) on the relationship between corporate reputation and performance.

\section{INSTITUTIONAL THEORY}

The other theoretical framework used for this dissertation is Institutional Theory. This theory focuses on aspects of social structure considering the processes by which structures, schemes, rules, norms, and routines become guidelines for social behavior (Scott, 2004). The creation, diffusion, adoption, and adaptation of these elements are explained in different components of institutional theory. For instance, Scott (1994) indicates that organizations, in order to survive, need to conform to the rules and norms 
placed in the environment (DiMaggio and Powell, 1983; Meyer and Rowan, 1977)

because institutional isomorphism will provide organizational legitimacy to the firm (Dacin, 1997; Deephouse, 1996; Suchman, 1995). It is common for MNCs to face diverse institutional environments as they expand globally. Pressures in host and home institutional environments exert fundamental influences on firms' competitive strategies (Porter, 1990) and practices; e.g., liability of foreignness (Zaheer, 1995).

Institutional theorists claim that the institutional environment, more than market pressures, can influence the development of formal structures in an organization. For example, new and innovative structures which improve the adopting organizations' technical efficiency are legitimized in the environment. Ultimately, these formal structures achieve a high level of legitimatization (sedimentation) where failure to adopt them is considered as irrational or negligent. At this point, other firms need to adopt these structures even if they do not improve their efficiencies, see figure 1 from (Tolbert and Zucker, 1996).

Figure 1. Process of institutionalization.

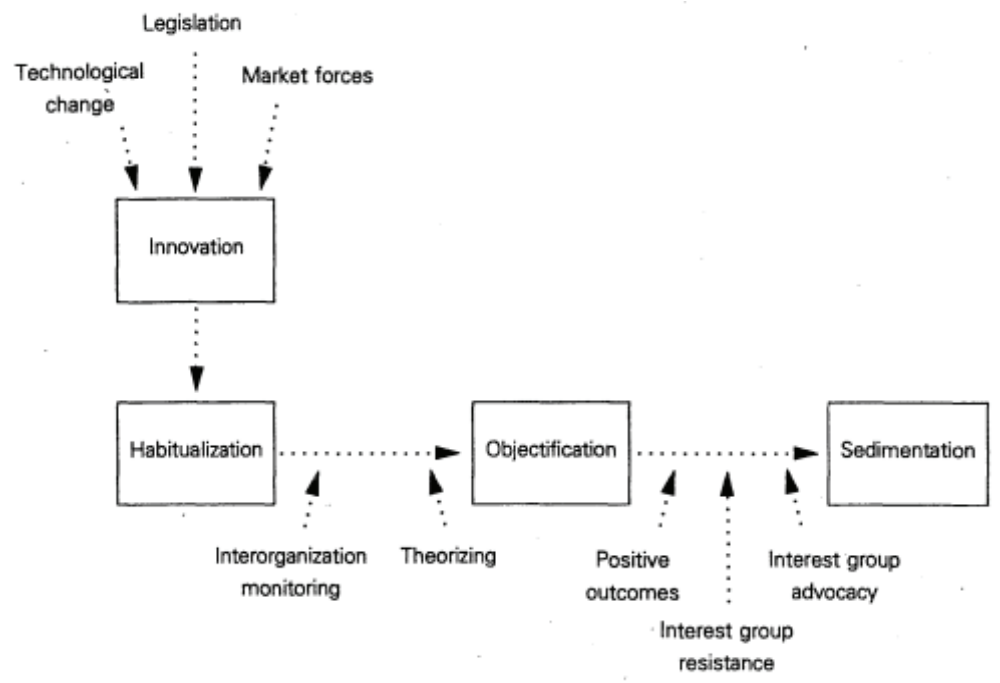

Source: Tolbert and Zucker (1996) 
Meyer and Rowan (1977) argue that these formal institutional structures, or “institutional myths", are accepted ceremoniously by the firm in order to gain or maintain legitimacy in the environment which is extremely important to ensure survival. DiMaggio and Powell (1983) conclude that the effect of institutional pressure is to homogenize organizational structures in an institutional environment. Firms will adopt organizational structures by three types of pressures (three pillars of institutions): coercive (e.g., rules, laws, sanctions), normative (e.g., certification, accreditation), and mimetic (e.g., prevalence, isomorphism) (DiMaggio and Powell, 1983; Scott, 1994). They added that the speed of institutional isomorphism is higher when firms are highly dependent on the institutional environment, rely extensively on professionals, and exist under high uncertainty.

Organizations need legitimacy and accountability within a society, but the problem attached to it is structural inertia (Hannan and Freeman, 1984; Nelson and Winter, 1982). Reliable performance requires that an organization continually reproduce its structure. Reproducibility is possible to achieve with routines (by institutionalization), but routines lead to standardization which leads to structural inertia. On the other hand, organizations that implement changes very often may produce very little inertia; however, they may have few chances for survival because they do not have routines in place. When a new organization is created, it has lower levels of reproducibility than the incumbents (older organizations). As a result, new organizations can adapt to environments easily or at least easier than highly-routinized organizations (Christensen, 1997; Alvarado-Vargas, 2008). These new entrant firms have high probability of failure 
in early stages of their life cycle. But, the failure rate declines as the organizations gets older.

Inertia can be explained as the resistance to environmental changes (Hannan and Freeman, 1984). In that study, the authors argued that inertia is a consequence of selection; in other words, organizations build organizational inertia because they do things right and customers (environment) approves their procedures and the organization continues to carry out activities in the same way. Thus, organizational inertia leading to routines and vice versa is evident. For the authors, organizational inertia is linked primarily to firm size and age; i.e. bigger and older firms have more organizational inertia. For some scholars, firm size and age are important characteristics for predicting success in organizations (Schumpeter, 1942). However, organizational inertia and routines may also be negative for an organization. If the environment is changing constantly, for example, in terms of technological advances, organizational inertia is disadvantageous (negative) for the firm because it will not be able to adapt to the new environment easily. Inertia is stronger at the core level of the organization and peripheral activities in the organization face less inertia (Hannan and Freeman, 1984).

Routines and organizational inertia are interrelated. Nelson and Winter (1982) investigated that individual skills and organizational capabilities may end up in organizational routines. These routines are the know-how for the firm and what in resource based view is called organizational capabilities. The main factor for organizational routines is repetition. Organizations create routines when the activity is repetitive; i.e. they perform the same activity constantly. In the case that knowledge is tacit, for example, routines are the best alternative to transfer that knowledge through the 
organization network. Tacit knowledge is knowledge that is very difficult and challenging to codify and, therefore, to transfer among units or individuals. In the case of an acquisition and/or joint venture, routines may be an important factor for success. If routines in specific organizations are strong, then the success rate would decrease when merging or acquiring organizations.

In the lines of institutional theory, other studies reflect a very similar explanatory logic. Pfeffer and Salancik's (1978) resource dependence theory is one of them. This theory explains how external resources to the firm and its dependence on them affect the behavior of the organization in terms of divisional structure, recruitment, production strategies, external links, and contract structure, among the most salient. This theory proposes that organizations without essential resources will be forced to establish relationships with other firms in order to obtain access to such resources, creating strong dependence. As a result, organizations attempt to adjust and minimize their dependence relationships with other firms. In this perspective, firms are observed as coalitions alerting their structure and patterns of behaviors in order to acquire and maintain needed resources. This theory has some assumptions. First, organizations are assumed to have internal and external coalitions resulting from social exchanges. Second, the environment is assumed to contain scarce, but valuable resources for organizational survival. The environment is responsible for posing the problem of organizations facing uncertainty in resource acquisition. Third, organizations are assumed to have two related objectives: acquiring control over needed resources, and minimizing their dependence on other firms. One of the options that Pfeffer and Salancik propose to minimize environmental dependences is vertical integration (acquisitions) (Hillman, Withers, and Collins, 2009; 
Pfeffer and Salancik, 1978). In this dissertation, acquisitions are assessed as an important mechanism for firms to get access to knowledge and new technology trends in the environment.

\section{INTERNATIONALIZATION THEORY AND DEGREE OF}

\section{INTERNATIONALIZATION}

For many decades, the literature in international business has studied the impact of the internationalization process and the degree of internationalization on the firm's performance reaching mixed results. For example, some scholars have argued that there is not a perceivable relationship between the degree of internationalization of a multinational firm and its performance (Haar, 1989; Rugman, 1983); on the other hand, other scholars have encountered a positive linear relationship (Buhner, 1987; Gomes and Ramaswamy, 1999; Grant, 1987; Grant, Jammine, and Thomas, 1988), an inverted Ushape relationship (Geringer and Hebert, 1989; Hitt, Hoskisson, and Kim, 1997), a Ushape relationship (Ruigrok and Wagner, 2003), and even a sigmoid-curve (3-stage) relationship (Contractor, Kundu and Hsu, 2003; Lu and Beamish, 2001).

Hennart (2007) and Verbeke and $\operatorname{Li}(2009)$ argue that there is a lack of theoretical rationale in order to support a general and well established multinationality-performance (M-P) relationship. This gap presents an important opportunity for proposing new theories for the M-P relationship and measures for the degree of internationalization (Kirca et al., 2011). These mixed results convey that more attention should be paid to measures of internationalization. 
As previously stated, the internationalization process has been widely studied during the last few decades in the field of international business. We have, for example, the Uppsala model which explains the different stages of the firm's internationalization process and shows that the internationalization process is incremental (Johanson and Vahlne, 1977). In other words, after firms start their international expansion, their subsequent investments in those foreign markets increase. For example, a firm may initially sell its products or services domestically. As its tangible and/or intangible resources grow and the domestic market reaches the upper limit, the firm looks for alternative markets to expand internationally. It may start exporting to foreign markets through an agent. Once the demand in the foreign market is significant, the firm may consider opening an office in the host country to internalize those operations. Later, the firm may consider starting production abroad in order to manage market imperfections, achieve economies of scale, or enjoy cost advantages provided by the host economy (Johanson and Vahlne, 1977). This stage represents the highest commitment from the firm with the foreign market.

Traditionally, international business scholars relied on the classic and neo-classic theories of international trade to explain the distribution for the foreign direct investment (FDI) (Nachum, 2000). It was during the decades of the late 1970s and early 1980s when John Dunning developed his eclectic paradigm (O-L-I) in the international business field. Since then, this theory has been vastly referenced when developing research in IB. Dunning's work is used to explain 'why' some MNCs expand internationally by creating subsidiaries in host countries, 'where' to locate them, and 'how' to enter new markets (entry mode choice) (Dunning, 1980, 1988). When a MNC decides to expand 
internationally, it can use the asset-exploitation or the asset-seeking strategy (Makino, Lau, and Yeh, 2002). For the former, the literature assumes that the MNC possesses certain resources (proprietary resources or skills) which can provide some monopolistic advantages in the foreign environment (Hymer, 1976). As a result, the company would go abroad to generate rents by using the mentioned resources. For the second strategy, literature explains that MNCs go abroad to develop new firm specific advantages or acquire necessary strategic assets, e.g., knowledge or new technologies, in foreign markets (Makino et al., 2002).

The importance of the internationalization measure was previously noted. As a result, the degree of internationalization (DOI) of the firm gained much attention by scholars in the mid 1990s (Ramaswamy, Kroeck, and Renforth, 1996; Riahi-Belkaoui, 1998; Sullivan, 1994, 1996). For example, Riahi-Belkaoui (1998), Grant (1987), Geringer, Beamish and daCosta (1989), and Daniels and Bracker (1989) measured the firm's degree of internationalization as the foreign sales as a percentage of total sales (FSTS). Others used export sales as a percentage of total sales (ESTS) (Sullivan and Bauerschmidt, 1989), foreign profits as a percentage of total profits (FPTP) (Eppink and van Rhijn, 1988), foreign assets as a percentage of total assets (FATA) (Daniels and Bracker, 1989), and overseas subsidiaries as a percentage of total subsidiaries (OSTS) (Stopford and Wells, 1972; Vernon, 1971). At a first glance, these DOI measures seem very simplistic, but very practical at the same time. Nevertheless, they have some flaws in their calculations which have been noted and criticized by researchers.

I use an example to pinpoint the limitations of those measures. In the case of FSTS, we assume there are two MNCs with international operations. The first sells $\$ 1$ 
million in France, \$1 million in Brazil, \$1 million in Japan, and \$10 million in the US. The DOI calculation (FSTS) for this company is $3 / 13$. The second company sells $\$ 3$ million in Canada and \$10 million in the US. The DOI calculation is also 3/13. However, the first company seemed more international, ex-ante. The other DOI measures provide similar flaws in their calculations. The number of countries in which the MNC operates should have some consideration on the DOI calculation to make it more accurate. In this doctoral dissertation, I propose a new DOI measure:

$$
\mathrm{DOI}_{\mathrm{i}}=\mathrm{C}_{\mathrm{i}} * \mathrm{OSTS}_{\mathrm{i}} * \mathrm{FSTS}_{\mathrm{i}} \quad \text { Equation (1) }
$$

Where:

$\mathrm{DOI}_{\mathrm{i}}$ is the degree of internationalization for the ith $\mathrm{MNC} ; \mathrm{C}_{\mathrm{i}}$ is the total number of countries in which the ith MNC operates (including the home country); OSTS $_{\mathrm{i}}$ is the number of foreign subsidiaries (affiliates) as a percentage of the total number of subsidiaries (affiliates) in the ith $\mathrm{MNC}$, and $\mathrm{FSTS}_{\mathrm{i}}$ is the foreign sales as a percentage of total sales in the ith MNC.

The proposed DOI measure assesses the call for many researchers to establish an internationalization measure which takes into account the breadth and depth of international operations (Thomas and Eden, 2004). Breadth of international operations is accounted by the OSTS ratio and the number of countries in which the MNC operates; both provide information about the percentage of foreign subsidiaries (affiliates) in the MNC network and how many countries are involved in the process. It can be thought as the number of rays emanating from a center point (nucleus), see figure 2 for a pictorial representation. In the pictorial example, the firm would have international operations in six countries ( 5 nodes plus the domestic market), and 27 foreign subsidiaries and 45 
domestic affiliates. Depth of international operations is accounted by the FSTS ratio. It provides information about the intensity of international operations in relationship to the entire operation basis. In terms of the nucleus analogy, depth would indicate the size of the nodes at the end of the rays emanating from the center (figure 2).

Figure 2. Breadth and depth of international operations

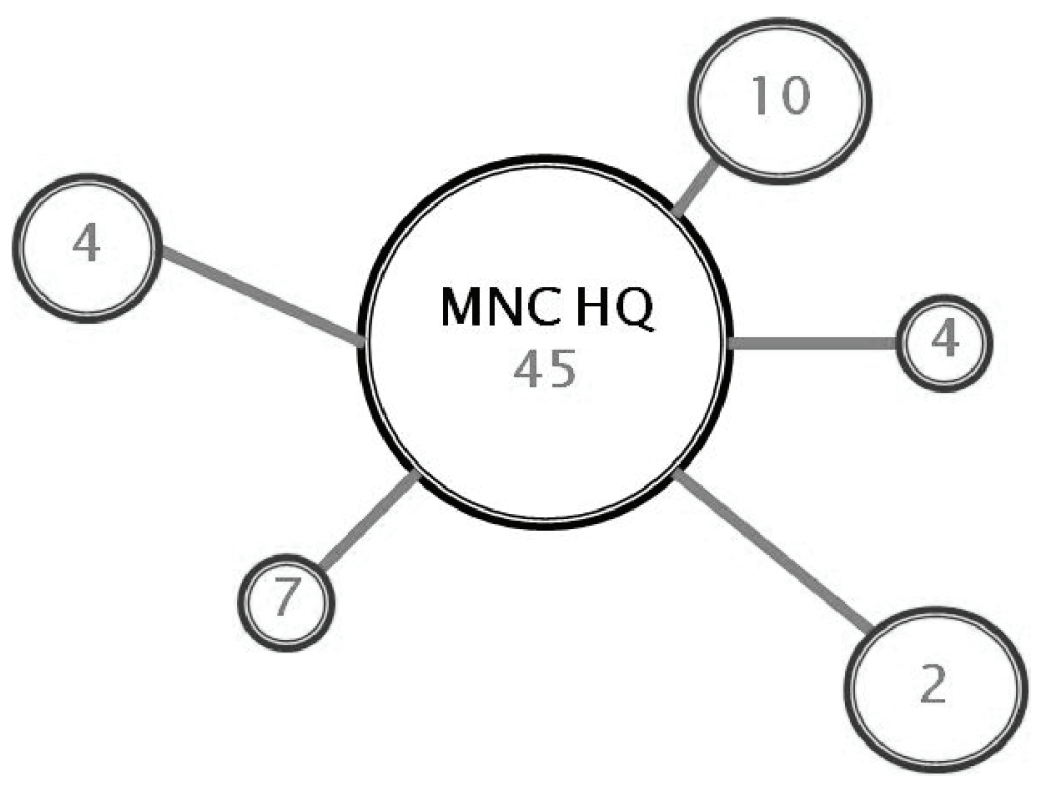

\section{FIRM REPUTATION}

In recent decades, firm reputation has received attention from management researchers and practitioners. The interest in corporate reputation is found in recent publications in different outlets such as the Financial Times, Fortune Magazine, and US News and World Report. These magazines published reputation scores for firms in different industries for several years. It has been noted before that there is almost a consensus about the positive effects of high firm reputation (Roberts and Dowling, 2002; Sabate and Puente, 2003). High levels of reputation give a firm distinct advantages such 
as its product and stocks are more appealing to customers and investors, more people want to join the firm (job seekers), generate more loyalty and motivation among its employees, better relationships with suppliers, and their risks with crises are fewer (Fombrun, 1996; Newburry, 2010). A highly reputed firm is perceived as "esteemed, worthy, and meritorious" according to Dollinger, Golden and Saxton (1997). Firm reputation is a valuable resource for the firm due to its "stickiness" (Fombrun, 1996; Fombrun and van Riel, 2004; Roberts and Dowling, 2002).

According to the Resource-Based View literature, firm reputation is considered a strategic factor which allows the firm to generate above-average rents (Barney, 1986). High firm reputation may provide competitive advantages for the firm given its VRIO (valuable, rare, inimitable, and non-substitutable) nature (Barney, 1991; Hall, 1992). Firm reputation has been also regarded as a source of value creation (Roberts and Dowling, 2002). On a different perspective, academicians in the marketing area have shed some light about the notion that high firm reputation is a signal of product quality and enables firms to charge higher prices for their services or products (Klein and Leffler, 1981). Using the Human Resource (HR) perspective, high firm reputation influences the employees' morale and productivity in a positive way (Garbett, 1988). High firm reputation minimizes transaction costs in terms of strategic alliances, joint ventures, or partnerships (Dollinger, Golden, and Saxton, 1997) because of trust vested in highly reputed firms. The above mentioned theoretical approaches, in their respective studies, consider firm reputation as a predictor for firm performance. The same structure is considered in this doctoral dissertation; however, the inclusion of firm innovation as a mediating factor is the main contribution. 
Firm reputation has a multidimensional nature. By examining its sources, we may find economic and non-economic constituents. For example, the work of Fombrun and Shanley (1990) and Garbett (1988) show that firm size is linked directly to firm reputation; stating that bigger firms possess higher firm reputation. Other studies proposed that accounting performance and the firm's risk profile are contributors to firm reputation (Roberts and Dowling, 2002). Media exposure and advertising have been pinpointed to play an important role in contributing to firm reputation (Bromley, 1993; Fombrun and Shanley, 1990; Garbett, 1988). Recently, corporate social responsibility and firm community involvement have been found to be good contributors for firm reputation (Sabate and Puente, 2003).

In addition to these studies, the effect of corporate strategy on firm reputation has been studied by other scholars. A firm's strategy provides information about the direction the firm intends to pursue; related stakeholders are then capable of evaluating those strategies and associate them to the firm reputation. For example, Williams, Schnake and Fredenberger (2005) proposed that firms pursuing a single business strategy obtain higher firm reputation compared to firms pursuing strategies with related or unrelated diversification. The explanation to this rationale is that firms pursuing a single business strategy provide a less ambiguous and clearer and more concise image in comparison to those firms with a diversification strategy. Stakeholders would be able to define the firm's business environment more clearly for firms following the single business strategy; this can be reflected in a higher firm reputation. Firms pursuing an unrelated diversification strategy might be perceived negatively by the stakeholders, affecting its reputation in the negative direction. 
Borrowing concepts from neo-institutional theory, organizations seek legitimacy in the environment they operate. Firms respond to different isomorphic pressures from the external environment (DiMaggio and Powell, 1983; Meyer and Rowan, 1977; Scott, 2007). Firm reputation is, therefore, a social construct and it depends on the capacity that the firm conforms to the cultural values, standards, and norms that prevail in a certain society or environment. As organizations employ institutionalized or 'accepted' procedures to achieve legitimacy, stakeholders compare and evaluate firms accordingly. Negative firm reputation may be granted to those companies which do not follow standard procedures used in the environment. As a result, firms wanting to secure a legitimate position in the environment need to meet and follow the standards placed in the environment.

Bergh et al. (2010) advanced the explanation of the relationship between corporate reputation and performance using other additional theoretical frameworks. The authors borrowed concepts from the resource-based view (previously explained), transactions costs economics (TCE) (Williamson, 1975; 1981), signaling theory (Spence, 1973), and social status research for their study. In the case of TCE, reputation has been characterized as a specific asset because it is particular to transacting partners (Williamson, 1981). Reputation can negatively influence the cost of a given transaction because the firm needs to identify and screen potential partners. Contrastingly, strong reputations may reduce incentives to act opportunistically reducing transaction costs. Reputation also affects the costs associated with negotiation, drafting, and enforcing contracts among partners. Summarizing, partners with higher reputation tend to be trusted more, they are not expected to act opportunistically, and contracts with them have lower 
costs. In the case of signaling theory (Spence, 1973), the author notes that this theory has been used to explain how external entities react to informational attributes of the firm, in this case its reputation. In essence, signals need to reduce the information asymmetries between low and high quality firms and the costs of the signal are higher for low quality firms; Basdeo et al. (2006) argued that firm reputation is influenced by its market actions and also by the actions of its industry rivals. Finally, social status involves creating and perpetuating differences within a group of entities. Status hierarchies evolve spontaneously in social settings and are based on social characteristics which are used to create performance expectations for internal and external entities to the firm. For example, we expect Apple Inc. and Google to be very innovative firms.

Although the antecedents and consequences of corporate reputation are important to study, this dissertation focuses more on the consequences, with economic outcomes the most prevailing. If we consider prices as the outcome variable, Benjamin and Podolny (1999) found that reputation for quality in winemakers was associated with higher prices. Or, Standifird (2001) showed that the final prices paid in eBay auctions were associated with the seller's ratings. Corporate recruiter scores for applicants are influenced by the applicant's school reputation (Boyd et al., 2010), or the school's reputation influences the starting salaries for recent graduated MBAs (Boyd et al., 2010; Rindova et al., 2005). If we consider firm financial performance, Deephouse (2000) argued that the level of favorable media coverage about a firm influenced the firm's return on assets. In the same line, Roberts and Dowling (2002) found a positive relationship between firm reputation and return on assets. Also, high firm reputation may give firms the benefit of doubt when negative information about them is available. For example, Pfarrer, Pollock and Rindova 
(2010) found that firms with higher reputations experience smaller stock market penalties for negative earnings surprises. Similarly, Love and Kraatz (2009) found that firms with higher reputations suffered less reputation loss after a firm downsizing.

Apart from the economic outcomes, other possible positive outcomes for the firm have been addressed by researchers. For instance, corporate reputation has been found to be related to attract more employees and customers (Turban and Cable, 2003). Jensen and Roy (2008) found that auditor reputation for technical expertise was an important factor to be selected by a given firm. In the context of mergers and acquisitions, Saxton and Dollinger (2004) found that a target firm's reputation was positively related to the acquirer assessment for the acquisition procedure. Deephouse and Carter (2005) found that high reputation allows banks to deviate from normal strategic behavior without significant loss of reputation. Although several consequences of corporate reputation have been explained in this section, human capital attraction, financial capital attraction, and the need for knowledge and new technology access are relevant for the dissertation. These high reputation consequences are related to the innovation capability of the firm.

\section{INNOVATION}

Important technological changes occurred in society in the last 150 years. Our routines at home and work have been transformed by new products and services; innovation has contributed to these changes in a profound manner. Hence, it is possible to argue that innovation is essential to social and economic progress (Dodgson and Gann, 2010; Schumpeter, 1942). In many industries, technological innovation is now the most important driver of competitive success and firms rely on products developed within the 
past five years for almost one third of their sales and profits (Barczak, Griffin and Kahn, 2009); hence, the importance of innovation for firms such as Johnson \& Johnson and 3M. However, innovation is still linked to high rates of failure in organizations because of our relatively limited understanding of its causes and effects. In this doctoral dissertation, innovation will occupy a mediating position between firm reputation and performance in order to contribute to the literature in advancing the understanding about innovation and its relationships. The literature in innovation remains so fragmented with no cumulative results (Ariss and Deilami, 2012) that we still do not have a clear general definition; many scholars have defined it according to their study requirements despite many attempts of scholars to establish one (Cooper, 1998; Garcia and Calantone, 2002). For example, Knight (1967), declares that an innovation is the adoption of a change which is new to an organization and the environment. Becker and Whisler (1967) assert that innovation as the first or early use of an idea by one or a set of organizations. Tushman and Nadler (1986) define that innovation is the creation of any product, service, or process which is new to a business unit. Thompson (1965) defined innovation as the generation, acceptance and implementation of new ideas, processes, products, or services. Betz (2003) defines technological innovation as both the invention of a new technology and its introduction into the marketplace. In other words, innovation is invention plus exploitation (Roberts, 2007). According to Garcia and Calantone (2002), the excess and diversity of definitions for innovation in the literature has resulted in ambiguity for researchers to measure relative constructs.

In this dissertation, innovation is defined as the creation of better or more effective and efficient products, processes, services, technologies, or ideas that are 
accepted by different stakeholders such as customers, institutions, and the society in general. Many other proposed definitions for innovation gravitate alongside this definition as exemplified in the previous paragraph. As the definition states, innovations are not only found in the activities that the firms do, but also in their processes (Dodgson and Gann, 2010); however, innovation will be assumed to be referring to product innovation for the rest of this dissertation. Innovation is normally linked to improvements in efficiency, productivity, and quality, among the most important and notable outputs.

Innovation is becoming more internationalized due to the effect of globalization and globalization of markets. As a result, potential sources of innovation are growing rapidly. For example, the location for innovation is changing to economies where the service sector is dominant. Currently, ownership and access to knowledge are more important and valuable than the possession of physical assets as in past decades. Innovation can arise from many different sources; for example, it can originate with individuals (inventors or users designing solutions for their own needs), research efforts of universities, government laboratories and incubators, or private nonprofit organizations. There are internal as well as external sources for innovation. Critics have often stated that firms are using external sources of technological innovation rather than investing in original in-house research. Empirical evidence shows that external sources of information are more likely to be complements to rather than substitutes for in-house research and development. Engaging in in-house R\&D helps to build the firm's absorptive capacity which refers to the firm's ability to understand and use new information (Cohen and Levinthal, 1990). Studies have shown that intangible assets (e.g., organizational and network capital) may be considered as drivers for innovation (Kramer, 
Marinelli, Iammarino and Revilla Diez, 2011). In this dissertation, corporate reputation, an intangible asset, is proposed as a driver for innovation.

Innovation plays an important role for the continuing existence of organizations.

Firms that do not innovate have a darker future in comparison to those firms in which innovation has a central strategic focus (Schumpeter, 1942). As a result, innovation is found in every organization, e.g., public institutions, not-for-profit organizations, and forprofit firms. For Schumpeter, capitalism can only be understood as an evolutionary process of continuous innovation and "creative destruction". He identified innovation as the critical dimension of economic change. He also argued that technological innovation often creates temporary monopolies, allowing abnormal profits which are faded away by rivals and imitators when they enter the marketplace. According to him, these temporary monopolies are required to provide incentives necessary for firms to develop new products and processes. He asserted that agents driving innovation and the economy are large companies because they have resources for research and development (Schumpeter, 1942). As a result, for him, large firms are more likely to innovate than small firms. Much research has addressed the relationship between firm size and innovation since Schumpeter's work; however, the debate is still ongoing (Antonelli and Calderini, 1999; Breschi, 1999; Malerba and Orsenigo, 1995). Empirical studies have reached contradicting results due to different innovation measures, sampling methods, and the size of firms included in the studies.

An important driver for innovation or technological change is the pressure for innovating product that external as well as internal stakeholders place on the firm (Adner and Levinthal, 2001); such pressure forces firms to search for and acquire knowledge and 
new technologies outside its boundaries. Sometimes, firms are clustered in regions or cities in order to facilitate and enjoy the benefit of knowledge exchange, e.g., Silicon Valley. Firms may want to stay close to these technological clusters to access technical spillovers. Technical spillovers occur when the benefits from the research activities of one firm spread to other firms; thus, spillovers are a positive externality in R\&D efforts (Jaffe, 1986, 1989; Jaffe, Trajtenberg and Henderson, 1993).

The natural evolution of technology and communication infrastructures allowed firms to have access to more technological knowledge within and outside the firm boundaries, developing a higher level of innovation (Fabrizio and Thomas, 2012). Firm specific resources are critical for innovation; slack in those resources has been proved to be disadvantageous for innovation. In other words, there is an inverted U-shape relationship between slack resources and innovation; too much and too little slack are detrimental for innovation (Nohria and Gulati, 1996).

Innovation can be manifested, as explained before, in products or processes. The nature of innovation can be incremental or radical (Chesbrough and Teece, 1996; Henderson and Clark, 1990). Incremental innovations are easier to execute and/or manage; therefore, it is not surprising that most innovations are incremental improvements of existing products and services (Dodgson and Gann, 2010). Innovation means changing well established routines within the organization and the environment; as a result, people are uncomfortable with the changes brought by innovations. People need to unlearn previous routines (Nelson and Winter, 1982), and re-learn new ones causing some inefficiency which is more relevant in radical innovations. Therefore, organizational inertia (Hannan and Freeman, 1984) or structural inertia is one of the 
reasons for innovation failures or slower innovation adoption (Alvarado-Vargas, 2008) because the initial pressures on keeping structures are strong. These pressures vary depending on the firm age, size, and structural complexity (Chandy and Tellis, 2000). One of the major postulations is that organizations with strong organizational inertia seldom succeed in making radical changes in strategy and structure in the face of environmental changes. Large firms commonly fail to develop radical or disruptive innovations partially because of the inability to unlearn obsolete mental models, riskaverse corporate climate, innovation process mismanagement, or poor infrastructure for innovation (Assink, 2006; Hill and Rothaermel, 2003). Some factors which favor incremental innovation include environmental dynamism, age and size of the firm (Koberg, Detienne and Heppard, 2003); in other words, larger and older firms posses enough resources for successful incremental innovations, but they fail when dealing with radical innovations (Christensen, 1997).

Investments in research and development are important for firm innovation; they enable firms to search for new ideas which may generate rents (Bresnahan, Stern and Trajtenberg, 1997; Teece, 1986); other studies showed the influence of mergers and acquisitions on innovation performance (Ahuja and Katila, 2001). Since a firm's ability to profit from an innovation depends on how well the newly acquired capabilities and technologies build on the firm's current capabilities (capabilities enhancing), the firm would be better off acquiring firms in which it is familiar; in other words, the firm will be better off acquiring firms in the same industry or region. Professor Roberts from MIT elaborates on the subject with what he terms the innovation dilemma: "[T]he further that any company seeks to innovate,..., the greater the likelihood that its innovation efforts 
will fail. And yet, the less that a firm seeks to innovate, across the board, the greater the likelihood that the corporation itself will fail” (Roberts, 2007). To be successful with a new technology, a firm needs new knowledge and capabilities which reinforce the firm's current competitive advantage. Since building these capabilities from scratch is very difficult, costly, and takes time, a firm may be better off acquiring the capabilities and knowledge from another firm through acquisitions (Roberts and Berry, 1986). Figure 3 shows the mechanisms to pursue technological change (Afuah, 2003). When the new technology and the market served are familiar to a company (cell IV), it has two options for profiting from the new technology: internal development and acquisitions. Acquisition of a firm which has developed the technology is preferred in situations where the firm needs the technology quickly because internal development (in-house R\&D) takes too much time and resources. In cell I, the new technology is familiar to the firm, but the market is not. In this case, the firm has three alternatives: joint venture, strategic alliance, or acquisitions. In a joint venture, firms form a separate legal entity; preferably, each firm brings to the relationship what the other firm is lacking, complementing their capabilities. Strategic alliances are weaker relationships compared to joint ventures or acquisitions. Access to the new technology or capabilities may be limited (Schilling, 2010). Acquisitions may be a better alternative for firms not familiar with the market. When the technology and market are not familiar to the firm (cell II), its existing capabilities are likely to be "useless". As a result, the firm may engage in educational acquisitions in which the firm buys another one not to keep it as a subsidiary, but for the sole purpose of learning from it. Finally in cell III, the technology is unfamiliar, but the 
market is familiar to the firm. So, the firm may engage in acquisitions in order to get access to the technology.

Figure 3. Mechanisms to pursue technological change.

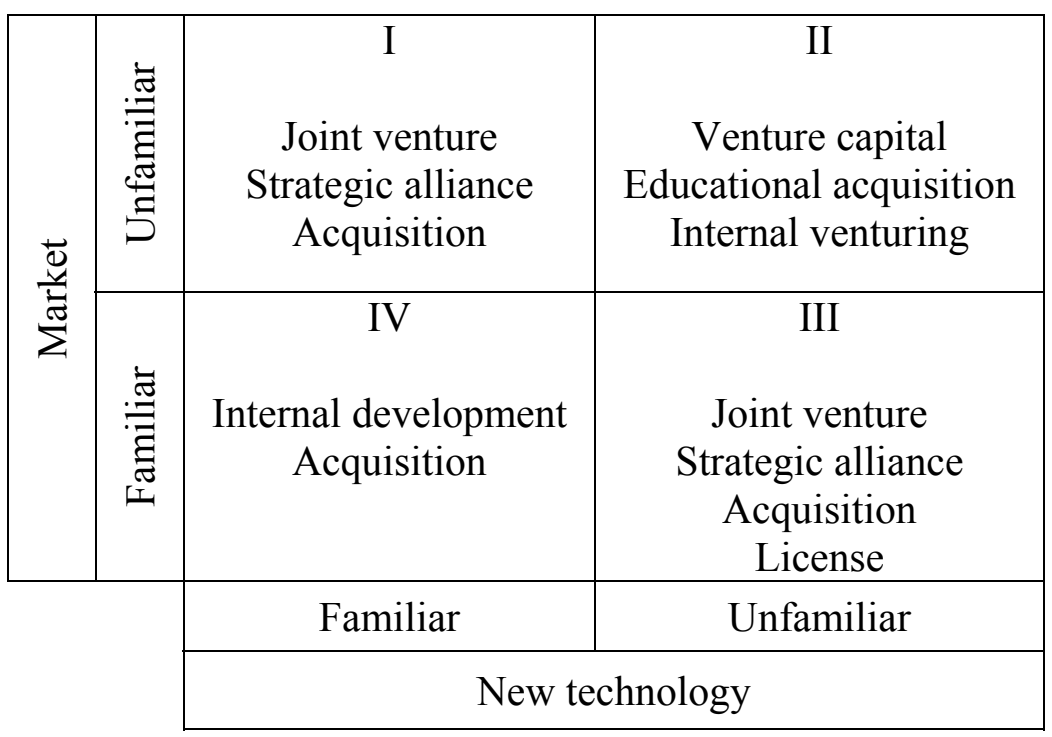

Source: Afuah (2003)

Technical innovation or product innovation has been related to firm performance (Damanpour, Szabat and Evan, 1989; Teece, 1986); however, the measure of innovation is a central debate in the technology management field. It is sometimes suggested that innovation is very difficult to quantify and measure (Smith, 2005); however, there seems to be an agreement to use $\mathrm{R} \& \mathrm{D}$ expenditures and patents information as plausible proxies for measuring it (Neely, 1999); in the United States, a patent is a property right granted by the federal government that restrains others from producing, using, or selling the invention (US Patents and Trademark Office). Other research relies on measurements derived from surveys among companies, or primary data. 


\section{CHAPTER III}

\section{THEORY DEVELOPMENT AND HYPOTHESES}

The relationship between firm reputation and performance has been previously studied. Scholars have reached conclusions that higher corporate reputation is positively related to higher firm performance (Bergh, Ketchen, Boyd and Bergh, 2010; Boyd, Bergh and Ketchen, 2010; Rindova, Williamson and Petkova, 2010; Roberts and Dowling, 2002). Within the Resource-Based View framework, firm reputation may be considered an intangible (V-R-I-O) resource which provides a competitive advantage to the firm (Barney, 1991) and consequently higher firm performance.

Since Schumpeter's argument about a darker future of firms which do not innovate, scholars have studied the impact of innovation on firm success and survival (Schumpeter, 1942). It has been argued that firms can profit from innovation (Teece, 1986) and innovation has been found to have a positive effect on firm performance (Bresnahan, Stern and Trajtenberg, 1997). In essence, firm reputation and innovation have been linked to firm performance independently in previous studies. However, there is a gap in the literature in terms of integrating these variables, providing room for this research. Thus, the principal objective and contribution of this doctoral dissertation is to test the mediating effect of innovation in the relationship between firm reputation and performance.

The conceptual model is shown in the following figure. As explained previously, the main objective of this dissertation is to study the linkage between corporate reputation and performance, using innovation capability as a mediating variable. More specifically, firm reputation is expected to have a positive impact on the level of firm innovation 
(innovation capability); at the same time, innovation capability is expected to be positively related to firm performance. The first relationship, i.e., corporate reputation and innovation capability, is achieved by attracting critical resources for innovation such as human capital, financial capital, and knowledge and technology access (acquisitions).

Other determinants for innovation have been studied before (e.g., firm size, firm age, accounting performance, etc); these determinants are considered as control variables in this dissertation.

Figure 4. Conceptual model

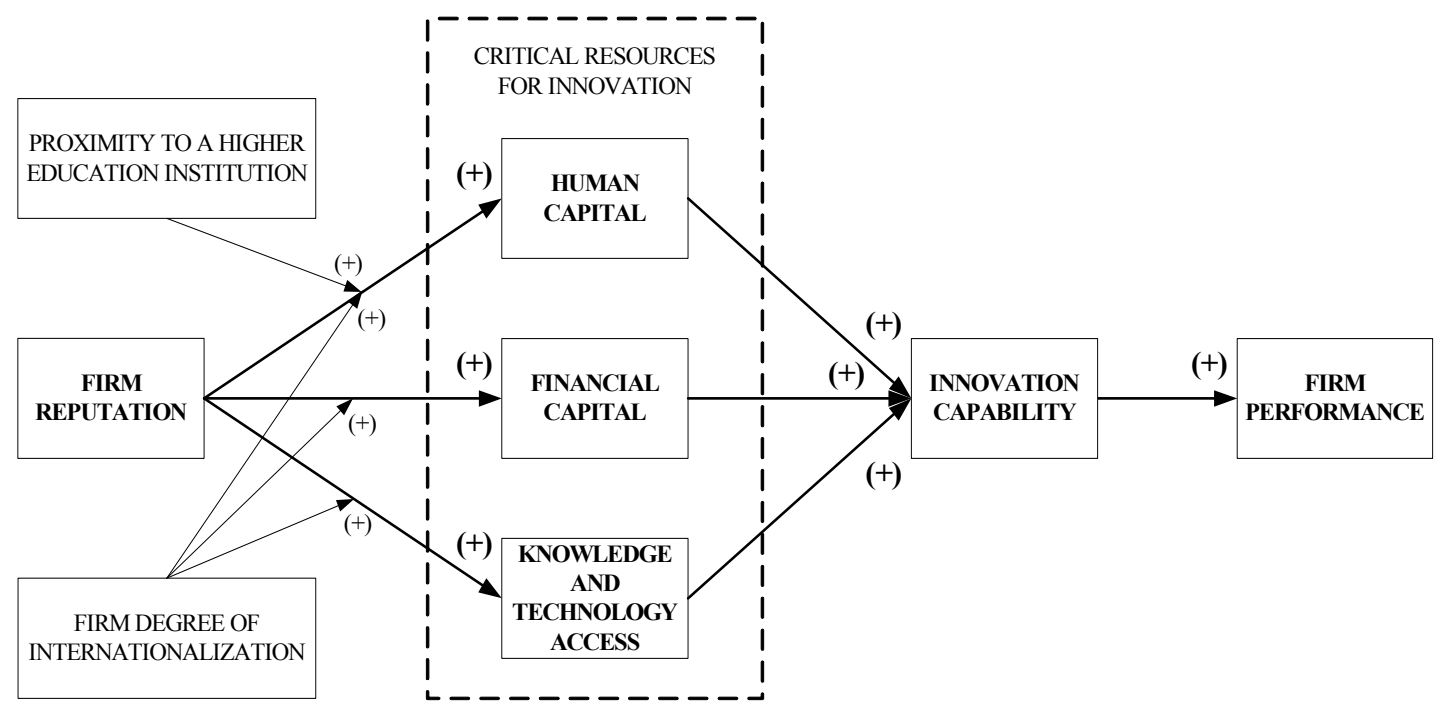

Firms with higher reputation are in an advantageous position to attract key agents for innovation, i.e., human capital. As found by Newburry (2010), reputation is positively associated with firm supportive behaviors such as workplace attractiveness. For example, these firms may be considered as attractive workplaces for newly graduated engineers who would be in charge of projects involving new product/service development (innovation). Or, it can be plausible to find eager university students considering these 
highly reputed firms as target for their internships. In addition, universities may be interested to create ties with these firms for internship programs and research centers. Firms with higher corporate reputation have a constant pressure by different stakeholders to have their products or services continuously improved by radical or incremental innovations. As a result, they need to have access to new technologies and knowledge.

New product development projects require financial resources which can be accessed internally or externally. Very often in organizations, the research and development team obtain little support from senior management when developing a radical innovation (Christensen, 1997; Leifer et al, 1994). One of the main explanations according to Christensen is that radical innovative products target markets which are not well developed and/or are very small for the firm's objectives. Therefore, senior management executives are reluctant to invest in those projects. In these cases, the research team might search for external financial resources such as private investors, or financial institutions which may be domestic or international. Better financial conditions and/or fewer guarantees may be applicable and requested to firms with higher level of reputation compared to those firms with lower levels.

The third component of critical resources for innovation is access to knowledge and new technologies through acquisitions. When the acquisition transaction is finalized, the focal firm may have access to other product developments and/or technology utilized by the acquired firm. By having access to these resources, the focal firm would increase its own level of innovation capability.

As observed in the model, firm reputation is positively related to these three critical resources for innovation. In simple words, the more reputation a firm has the 
more human capital, the better access to financial resources, and the more acquisitions the firm will achieve. These critical resources are needed in order to increase the level of innovation capability in a firm. Concurrently, these resources are positively related to firm innovation capability. Human capital, financial resources, and acquisitions will increase the innovation capability of the firm. Kramer et al. (2011) studied the linkages between intangible assets as drivers for innovation. In the dissertation, corporate reputation, an intangible asset, is considered as a driver for innovation.

In the model, two moderating effects are considered. First, a firm's degree of internationalization will positively moderate the relationship between firm reputation and the attraction of critical resources for innovation, i.e. human capital, financial capital, and knowledge base. For firms with a high degree of internationalization, the positive relationship between firm reputation and the attraction of critical resources for innovation will be stronger (steeper slope) than for firms with a low degree of internationalization. Second, universities were found to be a good source for critical resources for innovation (Kerr, 1963), more specifically, human capital. As a result, a firm whose headquarter is located closer to key higher education institutions may find it easier to attract human capital with certain skills such as newly graduated engineers in a certain field or university students considering temporal internships. Closer distance to these institutions will enhance the effect of the relationship between reputation and the human capital resource attraction.

For the first moderating variable, a new measure for the degree of internationalization is proposed in this doctoral dissertation as discussed previously. For this dissertation, the calculation of the degree of internationalization will be composed by 
three factors: the number of countries in which the MNC is located including the home country, the ratio of the number of foreign affiliates to the total number of affiliates (domestic and foreign), and the ratio of foreign sales to total sales. The first two factors combined will measure the breadth or dispersion of the MNC network; the third factor will measure the depth or intensity of foreign operations.

Finally, profiting from innovation has been already analyzed in previous studies (Teece, 1986). Consequently, the firm innovation capability is expected to be positively related to firm performance. Various studies used different financial indicators to assess firm success or performance; some of them used return on investment (ROI), return on equity (ROE), return on sales (ROS), return on assets (ROA) (Deephouse, 2000), and sales growth (Vissa and Chacar, 2009). These financial indicators are considered appropriate proxies for performance measurements and they are widely used in the literature. As a result, they are going to be used as proxies for firm performance herein. As the dissertation's main contribution is the mediating effect of innovation on the relationship between reputation and performance, I postulate the following overarching hypothesis.

Hypothesis 1. Firm's innovation capability mediates the relationship between firm reputation and performance such that firm reputation is positively related to firm innovation capability and consequently positively related to firm performance.

Once the mediating effect of innovation on the reputation-performance relationship has been addressed in $\mathrm{H} 1$, the three following hypotheses are concentrated 
on the attraction of critical resources for innovation, i.e. human capital, financial capital, and knowledge and technology access, based on high corporate reputation scores.

Firm reputation has a strong influence on people searching for employment (Cable and Graham, 2000). Organizational reputation affects workforce composition because of job seekers' initial attraction to organizations with higher reputation. Thus, it is very important for firms to possess a high reputation to attract high quality potential employees; scholars have argued that firm reputation may attract more and higher caliber applicants (Turban and Cable, 2003). In the case of innovation, this rationale is very critical; in order to have higher levels of innovation, firms need to employ human resources capable of performing those tasks. Job seekers may have been previously customers of the firm; as a result, they may found themselves inclined to work for the firm. For a company with high reputation, consumer enthusiasm and excitement can arguably arise (Henard and Dacin, 2010) and converge into the desire to work for that firm.

Reputation has two dimensions which are the stakeholders' perceptions of the firm producing higher quality products, and organizations' prominence in the minds of stakeholders, i.e. how stakeholders perceive firms (Rindova et al., 2005). This latter dimension is more salient for the attraction of human resources related to innovation because potential star employees would select and apply for jobs in firms which are highly recognized in the environment. Accordingly, I postulate hypothesis 2.

Hypothesis 2. Firm reputation is positively related to critical resources for firm innovation capability, more specifically, human capital. 
Firms are in constant pressure to obtain financial resources for growth, investments, and R\&D operations. Firms are searching for cheap sources of debt. High reputation may enhance the process of finding more advantageous sources of capital for the firms. Some of the benefits for firms with high reputation may include lower cost of capital, greater availability of capital, and less required collateral or guarantees, among the most salient (Bornheim and Herbeck, 1998). Lenders will monitor the borrower to a lesser extent when the borrower's credit worthiness and reputation are higher (Diamond, 1991). In case of a good standing in reputation and credit worthiness, lenders may adopt a position of arm's-length contract; in other words, less rigorous or less monitoring. Contrarily, lenders may use shorter lending periods with more strict contracts, and higher rates when firms have lower reputations (Rajan, 1992). In the latter situation, lenders possess more bargaining power compared to the firm. Consequently, I hypothesize the following:

Hypothesis 3. Firm reputation is positively related to critical resources for firm innovation capability, more specifically, financial capital (e.g. short and long term non-equity debts).

The number of acquisitions by US firms has been growing in the last decades. Recently, important mergers and acquisitions have been announced in the post-global financial crisis, e.g., the merger of American Airlines and US Airways, and a joint acquisition of the food conglomerate H.G Heinz by $3 \mathrm{G}$ and Berkshire Hathaway (Time magazine, February 2013). Acquisitions have become an important transaction 
governance form in the business environment if the objective is to possess more control and access to new technologies and capabilities. Firm reputation has been considered an important intangible resource for cooperation and the attraction of firm targets for acquisitions (Chen and Zeng, 2004; Dollinger et al., 1997; Fombrun and Shanley, 1990; Saxton and Dollinger, 2004; Servaes and Zenner, 1996). Mergers and acquisitions will provide full access to technologies that target firms possess prior the transaction. Firms are in constant pressure by stakeholders to keep high levels of innovation. As a result, firms need to develop new technologies in order to address the stakeholders' requests. Firms would face two possibilities. First, they can develop such new technologies inhouse. However, this option is costly in terms of resources and time. Second, firms may have access to new technologies from other organizations. This option (merger and/or acquisition) is quicker and less uncertain because most of the time they are proven and working technologies. Consequently, I postulate the following hypothesis.

Hypothesis 4. Firm reputation is positively related to knowledge and new technologies access, more specifically, firm acquisitions.

The positive effects of internationalization have been studied for many decades in the international business literature. These studies argued that internationalization represents a precondition for superior financial success (Ruigrok and Wagner, 2003); other benefits are economies of scale and scope (Buckley and Casson, 1976; Caves, 1971), portfolio diversification and an improvement on the companies' risk-return performance (Lessard, 1976). Other benefits associated with non-tangible measures are 
international image/visibility and corporate branding improvement (Burt and Sparks, 2002). In the 90 s, a very dynamic debate about the measure of internationalization, or degree of internationalization has been initiated, e.g., Ramaswamy et al. (1996) and Sullivan $(1994 ; 1996)$ due to the fact that diverse results were found when establishing the relationship between multinationality and performance. Currently, a standard DOI measure is not in place, which provides the opportunity to test for new alternatives for measuring the firm's DOI. As previously stated, I am proposing a new DOI measure which will assess the breadth and depth of international operations.

Hypothesis 5. A firm's DOI moderates the relationship between firm reputation and human capital for innovation such that for firms with higher level of DOI, the relationship is stronger.

Hypothesis 6. The firm's DOI moderates the relationship between firm reputation and financial capital (short and long term debts) for innovation such that for firms with higher level of DOI, the relationship is stronger.

Hypothesis 7. The firm's DOI moderates the relationship between firm reputation and knowledge and new technologies access (acquisitions) for innovation such that for firms with higher level of DOI, the relationship is stronger.

Collaborations between universities and firms to foster technical advancements are not new in the literature (Rosenberg and Nelson, 1994). In fact, it is commonly 
accepted that universities are critical sources of new knowledge, mainly in the fields of science and technology (Petruzzelli, 2011). In general terms, universities are inclined to build partnerships with firms for funding and research opportunities, filing patents for discoveries, creation of research centers, and/or the creation of internship programs to provide work experience for their graduates. By so doing, universities may increase the employment rate after graduation for their graduates. Firms also enjoy some advantages, e.g., higher quality of new hires, by collaborating with universities. Students who are at the top compared to their peers may have more access to research centers, internship programs, and research grants; also, they may obtain more exposure to potential employers. These students would be inclined to select better and highly reputed firms as their prospective employers. Accordingly, I propose that geographical distance from firms to universities will have a moderating effect on the relationship between highly reputed firms and the attraction of key human resources for innovation. Consequently, I propose the following hypotheses.

Hypothesis 8 . The proximity to a higher education institution moderates the relationship between firm reputation and human capital for innovation such that for firms closer to those institutions, the relationship is stronger.

For years, scholars have been studying the principal drivers, or determinants for innovation. They found internal as well as external sources for innovation (Romijn and Albaladejo, 2002). These include, for example, the professional background or employees skills (internal), intensity of networking, proximity advantages, and receipt of 
institutional support (external). Other scholars have found $R \& D$ expenditures, greater financial resources (slack resources) (Nohria and Gulati, 1996), technology transfer and networking to be the most influential determinants of innovation (Love and Roper, 1999; Rogers, 2004). In other attempts to study the antecedents of innovation, market structure, foreign ownership, firm age, firm size, and regional economic performance were argued to be important (Avermaete, Viaene, Morgan and Crawford, 2003). However, in this dissertation, these last determinants are considered as control variables. The following hypotheses argue that human and financial capital, as well as knowledge and new technologies access are determinants of innovation capability in the firm.

In innovation research, five kinds of individuals contributing to innovation have been studied: idea generators, gatekeepers and boundary spanners, champions, sponsors, and project managers (Afuah, 2003 pg. 37). As idea generators may be found throughout the firm, the number of employees (human capital for innovation) is expected to capture these effects. Firm size is captured by the total assets of the firm in this dissertation. The correlation between these two variables is less than 0.18 per year, which provides information that both variables, assumed to measure the firm size in the literature, are in fact not correlated.

Firms are in constant search for financial resources for innovation; previously, I explained that firms can borrow financial resources from a money-lending institution such as a bank acquiring a short or long term debt, which is a cheaper financial source compared to equity debt (Afuah, 2003). Banks also normally request collateral, such as physical assets. Firm reputation may reduce these requirements from lenders. In any event, financial resources are used to increase firm innovation capability. 
Acquiring a foreign or domestic firm gives the acquiring firm the advantage of control over the unit. However, some drawbacks are found in acquisitions: there might be a mismatch in the managerial styles and or organizational cultures between the acquiring firm and the target. Foreign acquisitions can be more expensive than domestic ones (Afuah, 2003). After the acquisition transaction is completed, the acquiring firm will have access to the target firm's knowledge base increasing its innovation capability. I postulate the following hypotheses.

Hypothesis 9. Human capital for innovation is positively related to firm innovation capability.

Hypothesis 10. Financial capital for innovation is positively related to firm innovation capability.

Hypothesis 11. Knowledge and new technologies access (acquisitions) is positively related to firm innovation capability.

Research studies argue that innovation is closely linked to firm performance and that it is possible to generate rents from innovation (Teece, 1986). The production of new products strengths the competitive position of the firm in relation to its competitors; this strategic position needs to be defended to achieve sustainable firm performance (Neely, 1999); in other words, innovation is necessary but not sufficient for a sustainable performance. It is important to note that firm performance is not an outcome due solely to 
innovation; other factors contribute to it. The moderating role of internationalization has been previously studied in efforts to explain the relationship between innovation and performance (Kafouros, Buckley, Sharp and Wang, 2008). However, in the following hypothesis I am postulating the direct relationship.

Hypothesis 12. Firm innovation capability is positively related to firm performance. 


\section{CHAPTER IV}

\section{SAMPLE, VARIABLES AND METHODOLOGY}

\section{SAMPLE}

This dissertation studies the mediating effect of innovation on the relationship between corporate reputation and performance in US firms. As a starting point, I looked at reputational scores publicly published in the Fortune America's Most Admired Companies website. Although 400+ firms' reputational scores are reported each year, the principal criterion for selecting companies to be added in the sample was that each company should have reputation scores reported each year from 2006 to 2012. This would allow a longitudinal panel data structure for the sample. As a result of this criterion, 211 firms met the requirement for inclusion in the dataset. All of them are American companies, publicly traded, and within the Fortune 500 America's Largest Corporations list. I considered expanding the year window for one previous year, i.e. 2005 , but the loss in the number of firms was considerable from 211 to 195 . This would have represented a decrease of $7.5 \%$ in the numbers of firms included in the dataset. However, if we considered firm-year observations, there would be an increment of 5.6\% in the observations $\left((195 * 8-211 * 7) /\left(211^{*} 7\right)\right)$. It was a trade-off between the number of firms included in the dataset vis-à-vis the number of observations. I decided to use the more conservative scenario in terms of observations. In other words, the sample dataset is for 2006 to 2012 with 211 US firms, providing 1,477 firm-year observations.

Multiple data sources were utilized in this dissertation to minimize common method bias. Sources such as COMPUSTAT database, Directory of Corporate Affiliation (DCA) database, Securities Data Company (SDC) Platinum database, Fortune America's 
Most Admired Companies, United States Patent and Trademark Office (USPTO)

database, and U.S. News Universities Rankings were important and the principal sources of data for this research.

Firms included in the sample dataset belong to different industries. The categorization was done by their respective Standard Industrial Classification (SIC) from the Occupational Safety and Health Administration (OSHA) from the US Department of Labor (USDOL). Each firm has a SIC code of 4 digits. In the table below, the different divisions are considering 1 digit grouping. For example, Division B is for companies in the mining industry and the 2-digit SIC codes are from 10 to 14 . Division C is for construction and SIC from 15 to 17. Division D is for manufacturing; SIC from 20 to 39. Division $\mathrm{E}$ is for transportation, communications, electric, gas, and sanitary services with SIC ranging from 40 to 49 . Division F is for wholesale trade with SIC ranging from 5051. Division G for retail trade, SIC from 52-59. Division $\mathrm{H}$ for finance, insurance, and real estate, SIC from 60 to 67 . Finally, Division I is for services with 2-digit SIC codes ranging from 70 to 89 . The specific frequencies and percentages of firms in each division are shown in table 2 . It is clearly noted that the proportion of manufacturing and service companies are almost balanced (37.91\% to 59.72\%), or 80 to 126 firms. Division B and division C (5 firms in total) could be considered as outliers in the study; however, they are included in all the analyses. As a result, a control dummy variable differentiating manufacturing versus service industry was created. In addition, the industry classification according to Fortune was recorded for robustness purposes. Details about variables will be provided in the next sections in this chapter. 
Table 2. Distribution of firms per SIC division.

\begin{tabular}{|l|c|c|}
\hline Industry_sic & Freq. & Percent \\
\hline Division B & 2 & 0.95 \\
\hline Division C & 3 & 1.42 \\
\hline Division D & 80 & 37.91 \\
\hline Division E & 22 & 10.43 \\
\hline Division F & 18 & 8.53 \\
\hline Division G & 29 & 13.74 \\
\hline Division H & 25 & 11.85 \\
\hline Division I & 32 & 15.17 \\
\hline Total & 211 & 100.00 \\
\hline
\end{tabular}

Companies are located in different cities and states within the continental U.S.

However, it is possible to note some concentration in some specific locations. The following table shows a summary of the number of firms within the same zip code. The zip code, the city and the state are reported if at least 3 firms are located in the same zip code and/or neighboring zip codes; the neighboring zip code was analyzed using an internet tool (http://maps.huge.info/zip.htm).

Table 3. Firms with similar geographical location.

\begin{tabular}{|c|c|c|c|}
\hline Zip Code & City & State & Num. of firms \\
\hline 10017 & \multirow{5}{*}{ New York } & \multirow{5}{*}{ NY } & 1 \\
\hline 10019 & & & 2 \\
\hline 10022 & & & 4 \\
\hline 10036 & & & 3 \\
\hline 10105 & & & 1 \\
\hline 20817 & Bethesda & $\mathrm{MD}$ & 3 \\
\hline 22042 & Falls Church & VA & 3 \\
\hline 30339 & Atlanta & GA & 3 \\
\hline 45202 & Cincinnati & $\mathrm{OH}$ & 4 \\
\hline 60015 & Deerfield & \multirow{3}{*}{ IL } & 3 \\
\hline 60026 & Glenview & & 2 \\
\hline 60045 & Lake Forest & & 1 \\
\hline 75039 & Irving & $\mathrm{TX}$ & 2 \\
\hline
\end{tabular}




\begin{tabular}{|l|c|c|c|}
\hline 75202 & Dallas & & 2 \\
\hline 94043 & Mountain View & \multirow{4}{*}{ CA } & 3 \\
\cline { 1 - 1 } 94065 & Redwood City & 2 \\
\hline 94088 & Sunnyvale & & 1 \\
\hline
\end{tabular}

Refer to the figure 5 for a pictorial representation of the firms with similar geographical location within the continental U.S. territory.

Figure 5. Firms with similar geographical location in the US

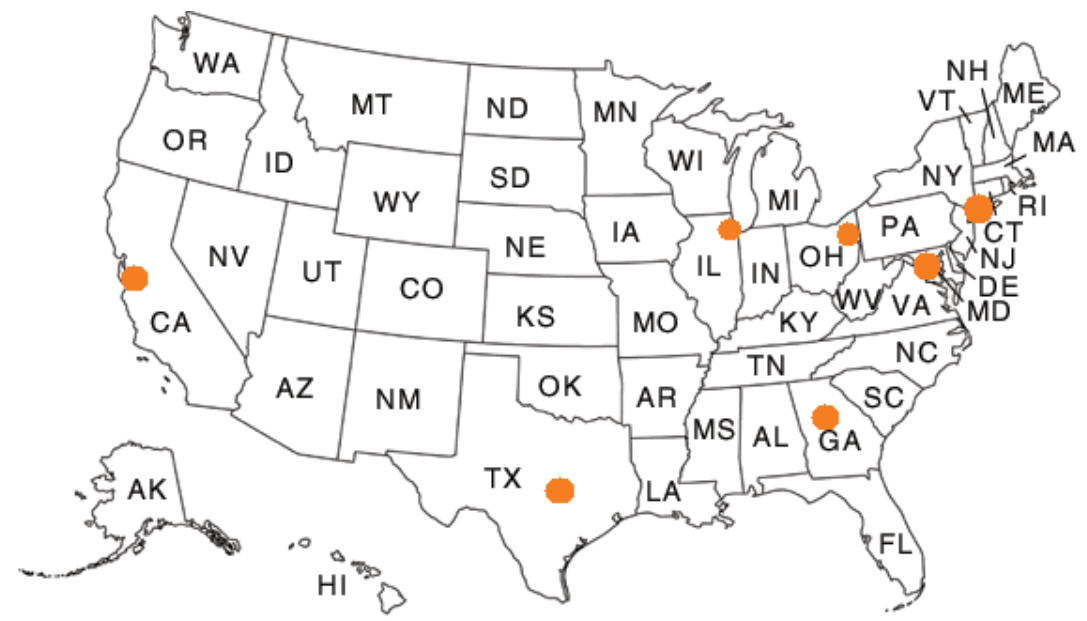

PR

Source: U.S. Department of Agriculture (base map). Own contribution (dots).

As explained before, 211 firms are included in the sample for this study with observations from 2006 to 2012 for all the variables explained in the following section. As a result, the structure of the sample is a longitudinal balanced panel dataset with 1,477 observations in total. Firms are American corporations, publicly traded, and within the Fortune 500 biggest American firms list; these attributes facilitated the data collection from different information sources making it possible to build a balanced dataset. 


\section{VARIABLES}

Previous chapters in this dissertation helped to explain how other researchers have operationalized the variables in their respective studies. In the following sections, I will explain the sources, measures, and characteristics of the variables utilized in this study. Some variables act as independent and/or dependent variables depending on the hypothesis they are testing; accordingly, their exogeneity or endogeneity are taken into account at the moment of hypotheses testing. The following table lists variables with independent, dependent, or both roles in the dissertation.

Table 4. List of selected variables and their roles in the dissertation

\begin{tabular}{|c|c|c|}
\hline Measure & Main variable (s) & Role \\
\hline Corporate reputation & $\begin{array}{c}\text { mac_score } \\
\text { rank_overall } \\
\text { rank_fortune } \\
\text { rank_sic }\end{array}$ & $\begin{array}{l}\text { Independent } \\
\text { Variable }\end{array}$ \\
\hline $\begin{array}{c}\text { Degree of } \\
\text { internationalization }\end{array}$ & $\begin{array}{l}\text { DOI_MJAV } \\
\text { DOI_FSTS }\end{array}$ & $\begin{array}{l}\text { Independent } \\
\text { Variable }\end{array}$ \\
\hline Distance to universities & $\begin{array}{l}\text { Totaldistance } \\
\text { dist_entrep } \\
\text { dist_eng } \\
\text { dist_mktg }\end{array}$ & $\begin{array}{l}\text { Independent } \\
\text { Variable }\end{array}$ \\
\hline Human capital attraction & Employees & Both \\
\hline Finacial capital attraction & $\begin{array}{l}\text { dlc } \\
\text { dltt }\end{array}$ & Both \\
\hline $\begin{array}{l}\text { Knowledge and technology } \\
\text { access }\end{array}$ & $\begin{array}{c}\text { num_acquisitions } \\
\text { same_coutry } \\
\text { same_SIC1 } \\
\text { same_SIC2 }\end{array}$ & Both \\
\hline $\begin{array}{l}\text { Average ownership per } \\
\text { acquisition }\end{array}$ & ownedaftertransaction & $\begin{array}{c}\text { Independent } \\
\text { Variable }\end{array}$ \\
\hline Innovation capability & $\begin{array}{c}\text { xrd } \\
\text { patents } \\
\text { inn_cap } \\
\text { rd_patent }\end{array}$ & Both \\
\hline
\end{tabular}




\begin{tabular}{|c|c|c|}
\hline Firm performance & $\begin{array}{c}\text { sales_growth } \\
\text { roa } \\
\text { ros } \\
\text { roe }\end{array}$ & $\begin{array}{c}\text { Dependent } \\
\text { Variable }\end{array}$ \\
\hline Firm age & $\begin{array}{c}\text { firm_age } \\
\text { year_founded }\end{array}$ & $\begin{array}{c}\text { Independent } \\
\text { Variable }\end{array}$ \\
\hline Firm size & assets_total & $\begin{array}{c}\text { Independent } \\
\text { Variable }\end{array}$ \\
\hline Financial crisis years & crisis_dummy & $\begin{array}{c}\text { Independent } \\
\text { Variable }\end{array}$ \\
\hline
\end{tabular}

\section{Dependent Variable}

Firm Performance. The "purely" dependent variable in this dissertation, firm performance, is continuous. It is measured principally as sales growth. Sales growth confers "economies of scale, increased power, the ability to withstand environmental jolts, and eventually, likely greater profits" (Vissa and Chacar, 2009, p. 1183). Also, as this dissertation is principally assessing intangible assets (e.g., corporate reputation, knowledge, innovation capability) which are very complex in their performance assessment or measurement, the most appropriate performance outcome is sales growth of the company. However, other measures are considered in the study for robustness checks. These other measures are return on assets (ROA), return on equity (ROE), and return on sales (ROS) (Deephouse, 2000). These financial indicators have been utilized in the literature to assess firm success or performance. These variables were obtained from COMPUSTAT database.

Independent Variables

Corporate Reputation. The first "purely" independent variable in this dissertation is corporate reputation. It is continuous ranging theoretically from 0 to 10 . However, 
values are observed from 2.67 to 8.6 as the maximum value from 2006-2012. It was obtained from the Fortune America's Most Admired Companies list from 2006 and 2012. As explained earlier, firms with reputation scores in the time window are included in the sample. In the dissertation, this variable is coded as "mac_score". The following table 5 shows the principal statistics of this variable. It is important to note the changes in corporate reputation previous, during, and after the financial crisis of 2008-2010. Specially, 2009 and 2010 were the years with the lowest mean in corporate reputation.

Table 5. Corporate reputation per year.

\begin{tabular}{|c|c|c|c|c|c|c|}
\hline Variable & Year & Obs & Mean & Std. Dev. & Min & Max \\
\hline $\begin{array}{c}\text { Reputation Score } \\
\text { [mac_score] }\end{array}$ & 2006 & 211 & 6.58 & 0.94 & 3.20 & 8.60 \\
\hline $\begin{array}{c}\text { Reputation Score } \\
\text { [mac_score] }\end{array}$ & 2007 & 211 & 6.50 & 0.90 & 3.50 & 8.53 \\
\hline $\begin{array}{c}\text { Reputation Score } \\
\text { [mac_score] }\end{array}$ & 2008 & 211 & 6.57 & 0.92 & 4.02 & 8.44 \\
\hline $\begin{array}{c}\text { Reputation Score } \\
\text { [mac_score] }\end{array}$ & 2009 & 211 & 6.21 & 1.04 & 3.02 & 8.56 \\
\hline $\begin{array}{c}\text { Reputation Score } \\
\text { [mac_score] }\end{array}$ & 2010 & 211 & 6.08 & 1.01 & 2.67 & 8.15 \\
\hline $\begin{array}{c}\text { Reputation Score } \\
\text { [mac_score] }\end{array}$ & 2011 & 211 & 6.15 & 0.97 & 2.80 & 8.22 \\
\hline $\begin{array}{c}\text { Reputation Score } \\
\text { [mac_score] }\end{array}$ & 2012 & 211 & 6.13 & 1.02 & 3.36 & 8.42 \\
\hline
\end{tabular}

From the reputation scores website, it was also possible to obtain the rank the company occupied in a specific year. In simpler terms, the $400+$ companies listed per year are ranked according to their reputation score; so, I recorded the position the companies included in the sample occupied in a certain year. I coded this variable as "rank_overall". Theoretically, this variable ranges from 1 to $400+$ and is ordinal. Table 6 summarizes the variable statistics. 
Table 6. Descriptive statistics of the overall rank per year.

\begin{tabular}{|c|c|c|c|c|c|c|}
\hline Variable & Year & Obs & Mean & Std. Dev. & Min & Max \\
\hline rank_overall & 2006 & 211 & 228.44 & 158.65 & 1 & 582 \\
\hline rank_overall & 2007 & 211 & 241.73 & 160.24 & 2 & 585 \\
\hline rank_overall & 2008 & 211 & 244.27 & 166.18 & 6 & 601 \\
\hline rank_overall & 2009 & 211 & 195.04 & 134.20 & 1 & 461 \\
\hline rank_overall & 2010 & 211 & 176.09 & 117.06 & 2 & 408 \\
\hline rank_overall & 2011 & 211 & 177.87 & 119.58 & 1 & 417 \\
\hline rank_overall & 2012 & 211 & 192.18 & 124.04 & 1 & 428 \\
\hline
\end{tabular}

In the literature, it was noted that corporate reputation scores vary across industries (Fombrun and Shanley, 1990; Rindova, Williamson, Petkova, and Sever, 2005); as a result, I recorded the rank order by industry. In the America's Most Admired Companies list, Fortune has its own classification of industries which varies from the SIC classification. Accordingly, I recorded the ranks with the Fortune classification. Then, I matched and converted the Fortune industry classifications into their SIC equivalence. Ranks were recorded taking into account the position the firms occupied from the complete list per year per industry (400+ firms). These variables are recorded as "rank_fortune" and "rank_sic". The following tables 7 and 8 list the number of firms in different ranks per year. Fortune industry classification has $40+$ items such as aerospace and defense, airlines, apparel, beverages, furniture, etc.

Table 7. Number of firms per year per rank-industry by Fortune classification

\begin{tabular}{|c|c|c|c|c|c|c|c|c|c|c|c|c|c|c|c|}
\hline \multirow{2}{*}{ Year } & \multicolumn{15}{|c|}{ rank_fortune } \\
\hline & 1 & 2 & 3 & 4 & 5 & 6 & 7 & 8 & 9 & 10 & 11 & 12 & 13 & 14 & 15 \\
\hline 2006 & 35 & 25 & 33 & 29 & 20 & 16 & 17 & 18 & 11 & 7 & 0 & 0 & 0 & 0 & 0 \\
\hline 2007 & 26 & 33 & 29 & 27 & 23 & 18 & 20 & 14 & 11 & 9 & 1 & 0 & 0 & 0 & 0 \\
\hline 2008 & 30 & 38 & 25 & 25 & 22 & 19 & 18 & 11 & 12 & 9 & 1 & 1 & 0 & 0 & 0 \\
\hline
\end{tabular}




\begin{tabular}{|c|c|c|c|c|c|c|c|c|c|c|c|c|c|c|c|}
\hline 2009 & 39 & 40 & 25 & 27 & 26 & 21 & 12 & 9 & 4 & 3 & 5 & 0 & 0 & 0 & 0 \\
\hline 2010 & 40 & 40 & 29 & 27 & 21 & 18 & 17 & 8 & 5 & 0 & 5 & 1 & 0 & 0 & 0 \\
\hline 2011 & 41 & 38 & 33 & 25 & 20 & 22 & 15 & 7 & 5 & 0 & 1 & 2 & 1 & 1 & 0 \\
\hline 2012 & 40 & 37 & 29 & 30 & 20 & 19 & 19 & 6 & 4 & 1 & 3 & 1 & 0 & 1 & 1 \\
\hline Total & 251 & 251 & 203 & 190 & 152 & 133 & 118 & 73 & 52 & 29 & 16 & 5 & 1 & 2 & 1 \\
\hline
\end{tabular}

In the case of "rank_sic", there are 8 divisions in which firms were ranked from the complete dataset of raw reputation scores $(400+$ firms $)$. The following table shows a summary of number of firms per industry SIC division per year.

Table 8. Summary of firms per industry division per year by SIC classification

\begin{tabular}{|c|c|c|c|c|c|c|c|c|c|}
\hline \multirow{2}{*}{ Year } & \multicolumn{7}{|c|}{ Division } & \multirow{2}{*}{ Total } \\
\cline { 2 - 10 } & B & C & D & E & F & G & H & I & \\
\hline $2006-2012$ & 2 & 3 & 80 & 22 & 18 & 29 & 25 & 32 & 211 \\
\hline
\end{tabular}

Degree of Internationalization. This variable is continuous and was calculated by using two databases: DCA (for the breadth of internationalization: number of countries in which the firm operates and foreign subsidiaries to total subsidiaries) and COMPUSTAT segments (for the depth of internationalization: foreign sales to total sales). This variable was coded as “DOI_MJAV". This method of calculating the degree of internationalization is another contribution of the dissertation providing more detail to the foreign sales to total sales DOI, or "DOI_FSTS". However, FSTS was obtained in order to run robustness checks in the models. The following table summarizes the descriptive statistics and correlation matrix between these measures. The correlation is significant $(\mathrm{p}<0.001)$. 
Table 9. Descriptive statistics of DOIs and correlation matrix.

\begin{tabular}{|c|c|c|c|c|c|c|}
\hline Variable & Mean & Std. Dev. & Min & Max & DOI_FSTS & DOI_MJAV \\
\hline DOI_FSTS & 0.31 & 0.23 & 0 & 0.95 & 1.00 & \\
\hline DOI_MJAV & 2.96 & 5.25 & 0 & 37.08 & 0.57 & 1.00 \\
\hline
\end{tabular}

Distance to universities. This variable is continuous and is calculated by the Euclidean distance between two locations (zip codes) in the US. First, I obtained the list of the top 5 universities in the areas of Marketing, Entrepreneurship, and Engineering as these disciplines are more related to innovation. The list was obtained from the US News Best Graduate Schools for 2012. It is assumed that these rankings do not change drastically within 5 years. Perhaps, the first ranked school descends to the second or third position, but the list of the top five would not be too different during the 2006-2012. I recorded the zip code of the universities in the disciplines and calculated the distance to the firm's headquarters zip code in miles. The distance calculation was made using an online tool (http://www.zip-codes.com/distance_calculator.asp). Then, I added the distances from the firm's headquarters to the top 5 universities in each discipline obtaining “dist_eng", "dist_mktg", and "dist_entrep” for engineering, marketing, and entrepreneurship, respectively. In order to calculate the total distance, "totaldistance", from the firm's headquarters to all of the universities in the list, i.e. top 5 universities in the 3 disciplines, I added the distances without repeating distances of universities that were ranked in more than one discipline as a top 5. For example, Harvard University was ranked in 2 disciplines as the top 5. The following table 10 summarizes the distances from the firm's headquarters to the universities. 
Table 10. Summary of distances to universities.

\begin{tabular}{|c|c|c|c|c|}
\hline Variable & Mean & Std. Dev. & Min & Max \\
\hline totaldistance & 11758.17 & 2926.93 & 9040.59 & 18354.67 \\
\hline dist_eng & 7076.74 & 1003.77 & 5185.06 & 9710.90 \\
\hline dist_mktg & 5380.26 & 2010.83 & 3714.11 & 9625.74 \\
\hline dist_entrep & 5891.24 & 2506.52 & 2967.55 & 10602.68 \\
\hline
\end{tabular}

Human capital attraction. This variable can be considered an independent or dependent variable contingent upon what hypothesis is being analyzed. In any event, the variable takes integer positive values as it refers to the number of employees in the firm. This variable was obtained from COMPUSTAT and cross-validated with the DCA database. Number of employees is considered a proxy for human capital attraction. It has been studied in the literature about the positive effects of reputation on people searching for employment (Cable and Graham, 2000), attraction of better quality human resources (Turban and Cable, 2003), and consumers' decision to work for highly reputed firms (Henard and Dacin, 2010). In the following table 11, the descriptive statistics are reported. The company with the smallest number of employees is World Fuel Services and the company with the largest is Walmart.

Table 11. Descriptive statistics of the number of employees per year.

\begin{tabular}{|c|c|c|c|c|c|}
\hline Variable & year & Mean & Std. Dev. & Min & Max \\
\hline employees & 2006 & 81635.56 & 149165.4 & 647 & $1,800,000$ \\
\hline employees & 2007 & 85388.48 & 156948.5 & 743 & $1,900,000$ \\
\hline employees & 2008 & 87744.51 & 168025.0 & 916 & $2,100,000$ \\
\hline employees & 2009 & 89402.10 & 166796.7 & 1,164 & $2,100,000$ \\
\hline employees & 2010 & 86706.17 & 163664.2 & 1,249 & $2,100,000$ \\
\hline employees & 2011 & 88273.41 & 164920.7 & 1,499 & $2,100,000$ \\
\hline employees & 2012 & 90903.97 & 172312.5 & 1,798 & $2,200,000$ \\
\hline
\end{tabular}


Financial capital attraction. Firms need financial resources for growth, investments, and R\&D operations. Two of the cheapest sources for financial capital are short- and long-term debt because equity (ownership) is not involved. This variable is continuous and obtained from COMPUSTAT database. It was coded as "dlc" and "dltt", for debt in current liabilities and long-term debt, respectively. In the first case, "dlc" represents the total amount of short-term notes and the current portion of long-term debt (debt due in one year). In the case of "dltt", the variable represents debt obligations due more than one year from the company's balance sheet date. The following table summarizes the descriptive statistics of both variables per year.

Table 12. Descriptive statistics of short- and long-term debt per year.

\begin{tabular}{|c|c|c|c|c|c|c|}
\hline Year & Variable & Obs & Mean & Std. Dev. & Min & Max \\
\hline \multirow{2}{*}{2006} & dlc & 211 & 10255.34 & 53594.12 & 0.00 & 429216.00 \\
\cline { 2 - 7 } & dltt & 211 & 8831.56 & 26876.17 & 0.00 & 212281.00 \\
\hline \multirow{2}{*}{2007} & dlc & 211 & 10898.69 & 61429.94 & 0.00 & 499293.00 \\
\cline { 2 - 7 } & dltt & 211 & 10096.21 & 30793.21 & 0.00 & 260804.00 \\
\hline \multirow{2}{*}{2008} & dlc & 211 & 11924.78 & 65271.84 & 0.00 & 562857.00 \\
\cline { 2 - 7 } & dltt & 211 & 11920.68 & 38362.45 & 0.00 & 326443.00 \\
\hline \multirow{2}{*}{2009} & dlc & 211 & 10517.12 & 52547.71 & 0.00 & 449196.00 \\
\cline { 2 - 7 } & dltt & 211 & 12992.44 & 39709.39 & 0.00 & 330067.00 \\
\hline \multirow{2}{*}{2010} & dlc & 211 & 8969.61 & 47588.34 & 0.00 & 423853.00 \\
\cline { 2 - 7 } & dltt & 211 & 14066.80 & 45936.89 & 0.00 & 377138.00 \\
\hline \multirow{2}{*}{2011} & dlc & 211 & 9524.05 & 50880.77 & 0.00 & 394572.00 \\
\cline { 2 - 7 } & dltt & 211 & 13928.87 & 44880.82 & 0.00 & 360681.00 \\
\hline \multirow{2}{*}{2012} & dlc & 211 & 9197.12 & 48316.29 & 0.00 & 387738.00 \\
\cline { 2 - 7 } & dltt & 211 & 13109.59 & 37506.98 & 0.00 & 315832.00 \\
\hline
\end{tabular}

Knowledge and technology access. This variable was obtained from the SDC Platinum database in the mergers and acquisitions module. The variable measures the total number of acquisitions per year made by the firm, "num_acquisitions". SDC 
Platinum provides information about the location of those acquisitions, as well as, the industry for the target firm, and the percentage of ownership prior and after the transaction. As a result, I recorded whether the acquisitions were made in the same country; i.e. United States, "same_country". Also, I recorded whether it was a related acquisition by the 1- and 2-digit SIC code for industry classification, "same_SIC1" and "same_SIC2", respectively. These variables are positive integers and their descriptive statistics are reported in the table below.

Table 13. Descriptive statistics for knowledge/technology access

\begin{tabular}{|c|c|c|c|c|c|c|}
\hline Year & Variable & Obs & Mean & Std. Dev. & Min & Max \\
\hline \multirow{4}{*}{2006} & num_acquisitions & 211 & 4.95 & 5.41 & 1 & 32 \\
\hline & same_country & 211 & 3.59 & 3.81 & 0 & 24 \\
\hline & sameSIC1 & 211 & 3.54 & 4.19 & 0 & 31 \\
\hline & sameSIC2 & 211 & 2.95 & 3.65 & 0 & 31 \\
\hline \multirow{4}{*}{2007} & num_acquisitions & 211 & 3.38 & 4.02 & 1 & 28 \\
\hline & same_country & 211 & 2.33 & 2.62 & 0 & 21 \\
\hline & sameSIC1 & 211 & 2.49 & 2.88 & 0 & 19 \\
\hline & sameSIC2 & 211 & 2.14 & 2.52 & 0 & 19 \\
\hline \multirow{4}{*}{2008} & num_acquisitions & 211 & 2.78 & 2.93 & 1 & 26 \\
\hline & same_country & 211 & 1.77 & 1.69 & 0 & 14 \\
\hline & sameSIC1 & 211 & 2.08 & 2.27 & 0 & 23 \\
\hline & sameSIC2 & 211 & 1.76 & 2.16 & 0 & 23 \\
\hline \multirow{4}{*}{2009} & num_acquisitions & 211 & 2.42 & 1.81 & 1 & 11 \\
\hline & same_country & 211 & 1.63 & 1.43 & 0 & 10 \\
\hline & sameSIC1 & 211 & 1.81 & 1.52 & 0 & 9 \\
\hline & sameSIC2 & 211 & 1.55 & 1.41 & 0 & 9 \\
\hline \multirow{4}{*}{2010} & num_acquisitions & 211 & 2.62 & 2.58 & 1 & 27 \\
\hline & same_country & 211 & 1.73 & 1.95 & 0 & 20 \\
\hline & sameSIC1 & 211 & 1.91 & 2.13 & 0 & 26 \\
\hline & sameSIC2 & 211 & 1.72 & 2.10 & 0 & 26 \\
\hline \multirow{4}{*}{2011} & num_acquisitions & 211 & 2.63 & 2.47 & 1 & 27 \\
\hline & same_country & 211 & 1.82 & 1.82 & 0 & 18 \\
\hline & sameSIC1 & 211 & 1.96 & 1.88 & 0 & 20 \\
\hline & sameSIC2 & 211 & 1.75 & 1.87 & 0 & 20 \\
\hline 2012 & num_acquisitions & 211 & 2.87 & 2.63 & 1 & 16 \\
\hline
\end{tabular}




\begin{tabular}{|c|c|c|c|c|c|c|}
\hline \multirow{2}{*}{ same_country } & 211 & 2.00 & 2.08 & 0 & 15 \\
\cline { 2 - 7 } & sameSIC1 & 211 & 2.00 & 1.84 & 0 & 13 \\
\cline { 2 - 7 } & sameSIC2 & 211 & 1.68 & 1.70 & 0 & 13 \\
\hline
\end{tabular}

Innovation capability. This variable was recorded from multiple sources:

COMPUSTAT, ORBIS, DCA, USPTO, and the firms' annual reports. The first variable is about the R\&D expenses, "xrd". It measures the amount of dollars invested in research and development that the firms spent in a given year. As a result, it is a continuous variable. Second, "patents" is an integer number which reflects the number of patents provided to the firm in a given year. Third, a measure of innovation efficiency was obtained by dividing R\&D expenses by the number of patents per year. This variable, "rd_patent" measures the amount of dollars spent per patent in a given year. In other words, it measures the efficiency of the firm to convert dollars spent in R\&D into patents in order to protect the intellectual property or knowledge. Finally, innovation capability, “inn_cap", was measured as a ratio between R\&D and revenues or sales; it provides information about how much commitment the firm has to research and development (innovation) compared to the sales or revenues it receives (Garcia and Calantone, 2002; Kaul, 2012). Descriptive statistics are reported in the following table.

Table 14. Descriptive statistics for innovation capabilities.

\begin{tabular}{|c|c|c|c|c|c|c|}
\hline Year & Variable & Obs & Mean & Std. Dev. & Min & Max \\
\hline \multirow{4}{*}{2006} & xrd & 211 & 559.09 & 1305.36 & 10.50 & 9094.00 \\
\cline { 2 - 7 } & patents & 211 & 115.90 & 229.21 & 22.00 & 1808.00 \\
\cline { 2 - 7 } & rd_patent & 211 & 4.59 & 7.12 & 0.23 & 63.03 \\
\cline { 2 - 7 } & inn_cap & 211 & 0.03 & 0.05 & 0.00 & 0.25 \\
\hline \multirow{2}{*}{2007} & xrd & 211 & 665.33 & 1429.79 & 6.50 & 8434.00 \\
\cline { 2 - 7 } & patents & 211 & 143.37 & 282.41 & 21.00 & 2111.00 \\
\hline
\end{tabular}




\begin{tabular}{|c|c|c|c|c|c|c|}
\hline \multirow{4}{*}{2008} & rd_patent & 211 & 4.67 & 7.47 & 0.12 & 59.30 \\
\cline { 2 - 7 } & inn_cap & 211 & 0.04 & 0.07 & 0.00 & 0.61 \\
\cline { 2 - 7 } & xrd & 211 & 691.33 & 1491.22 & 7.00 & 8487.00 \\
\cline { 2 - 7 } & patents & 211 & 139.73 & 255.09 & 39.00 & 1864.00 \\
\cline { 2 - 7 } & rd_patent & 211 & 4.68 & 7.56 & 0.11 & 61.34 \\
\hline \multirow{4}{*}{ inn_cap } & 211 & 0.03 & 0.05 & 0.00 & 0.32 \\
\cline { 2 - 7 } & xrd & 211 & 733.56 & 1572.14 & 7.20 & 9010.00 \\
\cline { 2 - 7 } & patents & 211 & 140.55 & 254.51 & 45.00 & 2043.00 \\
\cline { 2 - 7 } & rd_patent & 211 & 5.33 & 11.95 & 0.11 & 137.72 \\
\cline { 2 - 7 } & inn_cap & 211 & 0.04 & 0.06 & 0.00 & 0.40 \\
\hline \multirow{4}{*}{2010} & xrd & 211 & 677.08 & 1416.13 & 6.50 & 8714.00 \\
\cline { 2 - 7 } & patents & 211 & 160.75 & 281.86 & 55.00 & 2929.00 \\
\cline { 2 - 7 } & rd_patent & 211 & 3.71 & 6.35 & 0.08 & 64.95 \\
\cline { 2 - 7 } & inn_cap & 211 & 0.03 & 0.05 & 0.00 & 0.34 \\
\hline \multirow{4}{*}{2011} & xrd & 211 & 748.01 & 1628.06 & 9.00 & 10991.00 \\
\cline { 2 - 7 } & patents & 211 & 204.93 & 333.32 & 70.00 & 3121.00 \\
\cline { 2 - 7 } & rd_patent & 211 & 3.30 & 6.55 & 0.10 & 70.49 \\
\cline { 2 - 7 } & inn_cap & 211 & 0.03 & 0.05 & 0.00 & 0.31 \\
\hline \multirow{4}{*}{2012} & xrd & 211 & 798.96 & 1698.27 & 13.00 & 9811.00 \\
\cline { 2 - 7 } & patents & 211 & 211.72 & 300.05 & 72.00 & 2368.00 \\
\cline { 2 - 7 } & rd_patent & 211 & 3.30 & 7.14 & 0.11 & 75.12 \\
\cline { 2 - 7 } & inn_cap & 211 & 0.03 & 0.05 & 0.00 & 0.27 \\
\hline
\end{tabular}

\section{Control Variables}

The ownership after the acquisition transaction. This variable was coded as “ownedaftertransaction" and it was measured as the average of the firm's ownership after the deals for the acquisitions in a given year. The variable is continuous and positive. The source is SDC Platinum.

Firm age. This variable is positive and an integer. The firm founding year, "year_founded", was obtained from DCA database and it is subtracted from the years of the study time window. The variable is coded as "firm_age". 
Firm size. This variable is continuous based on total firm assets. "assets_total" was obtained from COMPUSTAT.

Financial crisis. This is a dummy variable, "crisis_dummy". It takes the value of 1 if the year is 2008,2009 , and 2010. It takes the value of 0 otherwise. This variable represents the years for the financial crisis in the U.S.

\section{METHODOLOGY}

The hypotheses were tested using the statistical software STATA (v.11). The estimation method was the Arellano-Bond linear dynamic panel-data (Arellano and Bond, 1991). The command in STATA is "xtabond". According to the help command in STATA, linear dynamic panel-data models include lags of the dependent variable as covariates and contain unobserved panel-level effects. These effects are correlated with the lagged dependent variables; as a result, standard estimators such as OLS provide inconsistent estimates. In order to fix this problem, Arellano and Bond (1991) developed a consistent generalized method of moments (GMM) estimator which takes into account the panel-level effects which is the "xtabond" command. Also, causality explanations are improved by using a longitudinal panel data structure (Allison, 1984).

This estimator is designed for datasets with many panels (211 firms) and few periods ( 7 years). It requires that there be no autocorrelation in the errors. As a result, differences are calculated for all the variables before estimating the coefficients; by so doing, the number of years in the dataset will be reduced to 6; from 2007-2012, as the 2006 observations will be used to calculate the first difference (2007-2006 values). 
Also, I configured the estimation method (xtabond) to lag the variables by 1 and 2 years prior to the year of estimation resulting in 4 years for the observations. In total 844 observations, or 211 firms for 4 years are available for the analyses and hypotheses testing. Figure 6 below shows the elimination of 2006 as it is used for the first difference to reduce autocorrelation and the four possible runs with 2 and 1 year lag effects of the independent (IV) and dependent (DV) variables on the dependent variable at time " $t$ ".

In other words, $\mathrm{DV}(\mathrm{t})=\mathrm{IV}(\mathrm{t}-2)+\mathrm{IV}(\mathrm{t}-1)+\mathrm{DV}(\mathrm{t}-2)+\mathrm{DV}(\mathrm{t}-1)$

Figure 6. Lags for the linear dynamic panel data methodology

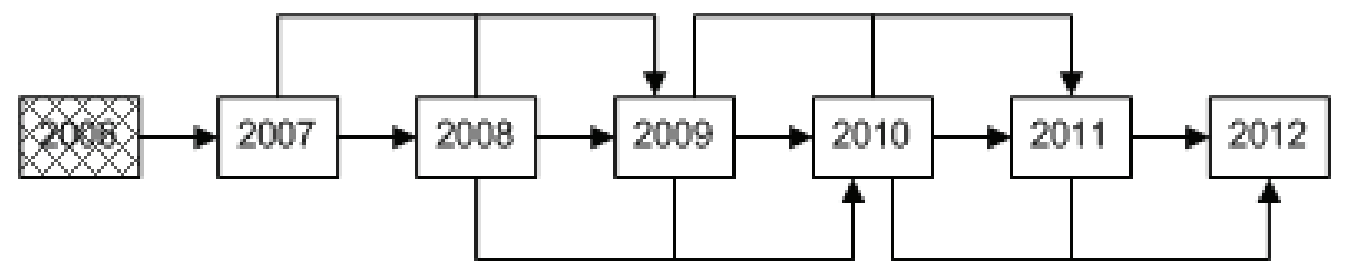

The major contribution of this doctoral dissertation is to empirically test the mediating effect of innovation capability ( $R \& D$ expenses) between corporate reputation and performance. A basic mediating variable model can be observed in the following figure 7 adapted from MacKinnon, Lockwood, Hoffman, West and Sheets (2002). 
Figure 7. Structure of a basic mediating effect.

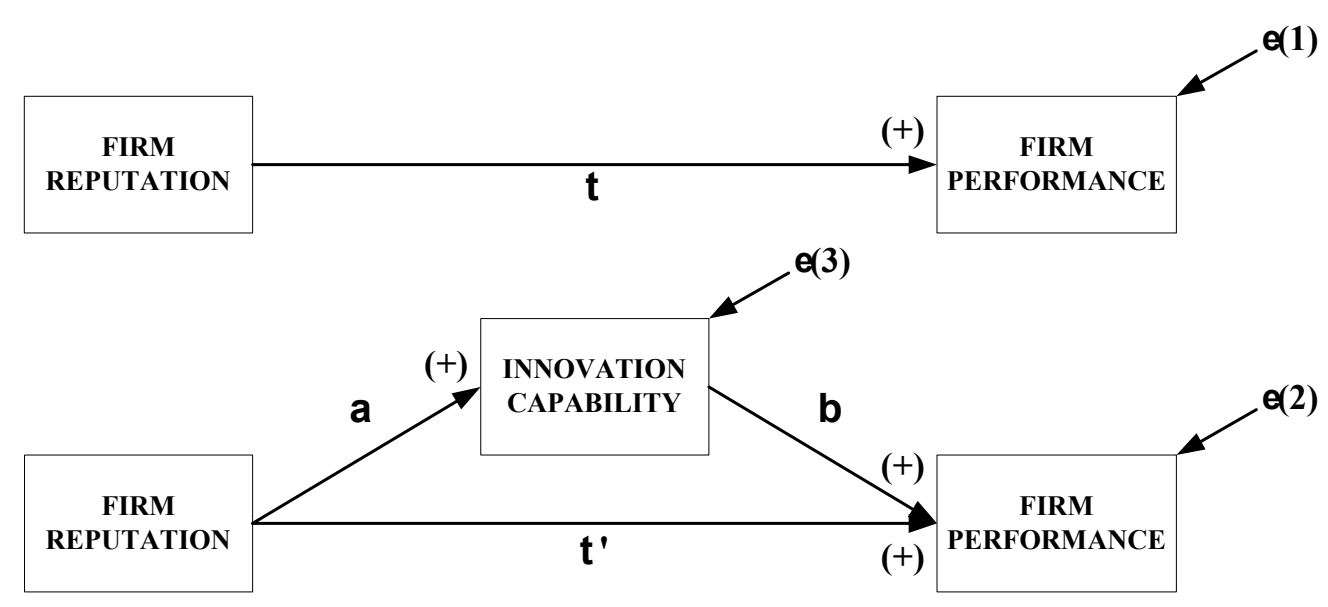

Source: Adapted from Mackinnon et al. (2002)

The equations used to estimate the mediating effect follow studies by Baron and Kenny (1986) and MacKinnon et al. (2002).

Performance $=\mathrm{g} 0(1)+$ tau $*$ Reputation $+\mathrm{e}(1) \quad$ Equation 4-1

Performance $=\mathrm{g} 0(2)+$ tau' $*$ Reputation + beta $*$ Innovation $+\mathrm{e}(2) \quad$ Equation 4-2

Innovation $=\mathrm{g} 0(3)+$ alpha $*$ Reputation $+\mathrm{e}(3) \quad$ Equation 4-3

In these equations, Reputation is the independent variable, Performance is the dependent variable, and Innovation is the mediating variable. $\mathrm{g} 0(1), \mathrm{g} 0(2)$, and $\mathrm{g} 0(3)$ are the regression intercepts in Equations 4-1, 4-2, and 4-3, respectively. "tau" represents the relationship between the independent and dependent variables in Equation 4-1, " tau" " represents the relationship between the independent and dependent variables adjusted for the effects of the mediating variable in Equation 4-2, "alpha" represents the relationship between the independent and mediating variables in Equation 4-3, "beta" represents the relationship between the mediating and the dependent variables adjusted for the effect of 
the independent variable in Equation 4-2, and e(1), e(2), and e(3) are the residuals in Equations 4-1, 4-2, and 4-3, respectively.

In order to test the mediating effect, first, the direct effect between corporate reputation and performance must be confirmed (Equation 4-1), i.e. the coefficient needs to be significant. Once results show statistical significance, Equation 4-3 is tested to show relationship between the predictor variable and the mediating variable. Results need to show a significant coefficient between these variables. Later, Equation 4-2 is tested to confirm the hypothesis about the mediating effect of innovation on corporate reputation and performance. Fully mediating effects are rare in social sciences studies (Baron and Kenny, 1986); therefore, I expect to find partially mediated effects in the statistical testing. In other words, I expect " tau" " and "beta" to be statistically different from zero in Equation 4-2. The mediating analysis in this dissertation will be performed using the Arellano-Bond dynamic linear panel data estimation method. 


\section{CHAPTER V}

\section{RESULTS}

As a first step in this section, I report the descriptive statistics table for all the variables which will be considered for the hypotheses testing. The structure of the study is longitudinal panel data; as a result, results are reported on a yearly basis. For organization purposes, only tables for 2006 and 2012, i.e. the first and last year in the database, are reported below (Tables 15 and 16, respectively). The coding for the variables names is explained in the previous chapter.

Table 15. Descriptive statistics for 2006.

\begin{tabular}{|c|c|c|c|c|}
\hline Variable & Mean & Std. Dev. & Min & Max \\
\hline mac_score & 6.58 & 0.94 & 3.20 & 8.60 \\
\hline rank_overall & 228.44 & 158.65 & 1.00 & 582.00 \\
\hline rank_fortune & 4.40 & 2.64 & 1.00 & 10.00 \\
\hline rank_sic & 44.86 & 41.81 & 1.00 & 201.00 \\
\hline employees & 81635.56 & 149165.40 & 647.00 & 1800000.00 \\
\hline manufacturing_dummy & 0.38 & 0.49 & 0.00 & 1.00 \\
\hline dist_entrep & 5891.24 & 2511.63 & 2967.55 & 10602.68 \\
\hline dist_mktg & 5380.26 & 2014.93 & 3714.11 & 9625.74 \\
\hline dist_eng & 7076.74 & 1005.82 & 5185.06 & 9710.90 \\
\hline totaldistance & 11758.17 & 2932.89 & 9040.59 & 18354.67 \\
\hline Dom_sales & 17626.22 & 21461.23 & 984.00 & 129041.00 \\
\hline Frg_sales & 8355.64 & 20601.47 & 0.00 & 252680.00 \\
\hline Tot_sales & 25981.86 & 36934.45 & 1443.60 & 365467.00 \\
\hline DOI_FSTS & 0.29 & 0.22 & 0.00 & 0.87 \\
\hline subsidiary_USA & 43.55 & 88.47 & 0.00 & 982.00 \\
\hline subsidiary_notUSA & 17.55 & 33.17 & 0.00 & 261.00 \\
\hline subsidiary_total & 61.10 & 103.57 & 1.00 & 996.00 \\
\hline FsubTsub & 0.28 & 0.29 & 0.00 & 1.00 \\
\hline num_country & 9.65 & 12.54 & 1.00 & 73.00 \\
\hline DOI_MJAV & 2.17 & 4.27 & 0.00 & 29.20 \\
\hline dlc & 10255.34 & 53594.12 & 0.00 & 429216.00 \\
\hline dltt & 8831.56 & 26876.17 & 0.00 & 212281.00 \\
\hline num_acquisitions & 4.95 & 5.41 & 1.00 & 32.00 \\
\hline & & & & \\
\hline
\end{tabular}




\begin{tabular}{|c|c|c|c|c|}
\hline same_country & 3.59 & 3.81 & 0.00 & 24.00 \\
\hline sameSIC2 & 2.95 & 3.65 & 0.00 & 31.00 \\
\hline sameSIC1 & 3.54 & 4.19 & 0.00 & 31.00 \\
\hline firm_age & 71.88 & 47.24 & 5.00 & 222.00 \\
\hline xrd & 559.09 & 1305.36 & 10.50 & 9094.00 \\
\hline patents & 115.90 & 229.21 & 22.00 & 1808.00 \\
\hline inn_cap & 0.03 & 0.05 & 0.00 & 0.25 \\
\hline rd_patent & 4.59 & 7.12 & 0.23 & 63.03 \\
\hline assets_total & 67872.62 & 202635.50 & 774.98 & 1884318.00 \\
\hline net_income & 2293.34 & 4692.31 & -12613.00 & 39500.00 \\
\hline sales_growth & 0.12 & 0.16 & -0.33 & 1.28 \\
\hline Sales & 29282.97 & 45348.40 & 1243.28 & 345977.00 \\
\hline Ros & 0.08 & 0.09 & -0.46 & 0.40 \\
\hline Roa & 0.07 & 0.06 & -0.32 & 0.31 \\
\hline Roe & 0.19 & 0.51 & -3.04 & 4.34 \\
\hline
\end{tabular}

Table 16. Descriptive statistics for 2012.

\begin{tabular}{|c|c|c|c|c|}
\hline Variable & Mean & Std. Dev. & Min & Max \\
\hline mac_score & 6.13 & 1.02 & 3.36 & 8.42 \\
\hline rank_overall & 192.18 & 124.04 & 1.00 & 428.00 \\
\hline rank_fortune & 3.96 & 2.64 & 1.00 & 15.00 \\
\hline rank_sic & 38.08 & 29.96 & 1.00 & 123.00 \\
\hline employees & 90903.97 & 172312.50 & 1798.00 & 2200000.00 \\
\hline manufacturing_dummy & 0.38 & 0.49 & 0.00 & 1.00 \\
\hline dist_entrep & 5891.24 & 2511.63 & 2967.55 & 10602.68 \\
\hline dist_mktg & 5380.26 & 2014.93 & 3714.11 & 9625.74 \\
\hline dist_eng & 7076.74 & 1005.82 & 5185.06 & 9710.90 \\
\hline totaldistance & 11758.17 & 2932.89 & 9040.59 & 18354.67 \\
\hline Dom_sales & 22049.91 & 25855.49 & 407.00 & 151298.00 \\
\hline Frg_sales & 11994.99 & 24850.21 & 0.00 & 301825.00 \\
\hline Tot_sales & 34044.90 & 43053.41 & 1545.03 & 453123.00 \\
\hline DOI_FSTS & 0.33 & 0.24 & 0.00 & 0.95 \\
\hline subsidiary_USA & 30.93 & 42.52 & 0.00 & 302.00 \\
\hline subsidiary_notUSA & 20.59 & 34.29 & 0.00 & 246.00 \\
\hline subsidiary_total & 51.52 & 63.51 & 1.00 & 422.00 \\
\hline FsubTsub & 0.36 & 0.30 & 0.00 & 1.00 \\
\hline num_country & 11.52 & 12.55 & 1.00 & 61.00 \\
\hline DOI_MJAV & 3.38 & 5.63 & 0.00 & 32.52 \\
\hline dlc & 9197.12 & 48316.29 & 0.00 & 387738.00 \\
\hline & & & & \\
\hline & & & \\
\hline
\end{tabular}




\begin{tabular}{|c|c|c|c|c|}
\hline dltt & 13109.59 & 37506.98 & 0.00 & 315832.00 \\
\hline num_acquisitions & 2.87 & 2.63 & 1.00 & 16.00 \\
\hline same_country & 2.00 & 2.08 & 0.00 & 15.00 \\
\hline sameSIC2 & 1.68 & 1.70 & 0.00 & 13.00 \\
\hline sameSIC1 & 2.00 & 1.84 & 0.00 & 13.00 \\
\hline firm_age & 77.70 & 47.14 & 11.00 & 228.00 \\
\hline xrd & 798.96 & 1698.27 & 13.00 & 9811.00 \\
\hline patents & 211.72 & 300.05 & 72.00 & 2368.00 \\
\hline inn_cap & 0.03 & 0.05 & 0.00 & 0.27 \\
\hline rd_patent & 3.30 & 7.14 & 0.11 & 75.12 \\
\hline assets_total & 90125.98 & 251751.20 & 1277.14 & 2209974.00 \\
\hline net_income & 2570.34 & 5634.63 & -12650.00 & 44880.00 \\
\hline sales_growth & 0.03 & 0.12 & -0.75 & 0.73 \\
\hline Sales & 36692.01 & 54319.94 & 1545.03 & 462534.00 \\
\hline Ros & 0.07 & 0.09 & -0.56 & 0.32 \\
\hline Roa & 0.05 & 0.07 & -0.30 & 0.34 \\
\hline Roe & 0.47 & 4.86 & -4.01 & 70.38 \\
\hline
\end{tabular}

The distributions of the observations per year on selected variables are shown in the following figures. For organization purposes, I am reporting the box plots for the reputation scores, degree of internationalization (FSTS), and sales growth. 
Figure 8. Box plot for reputation scores per year.

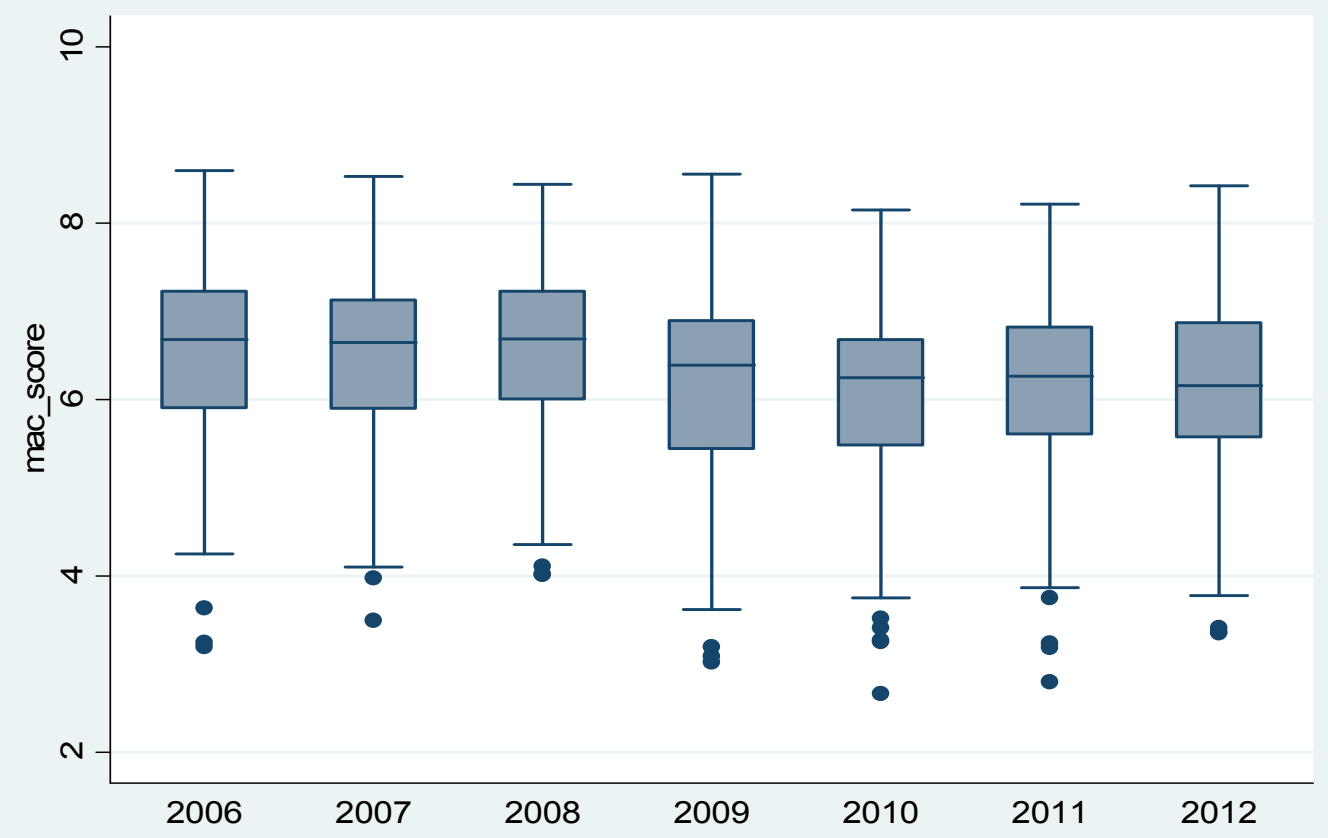

Figure 9. Box plot for degree of internationalization (FSTS) per year.

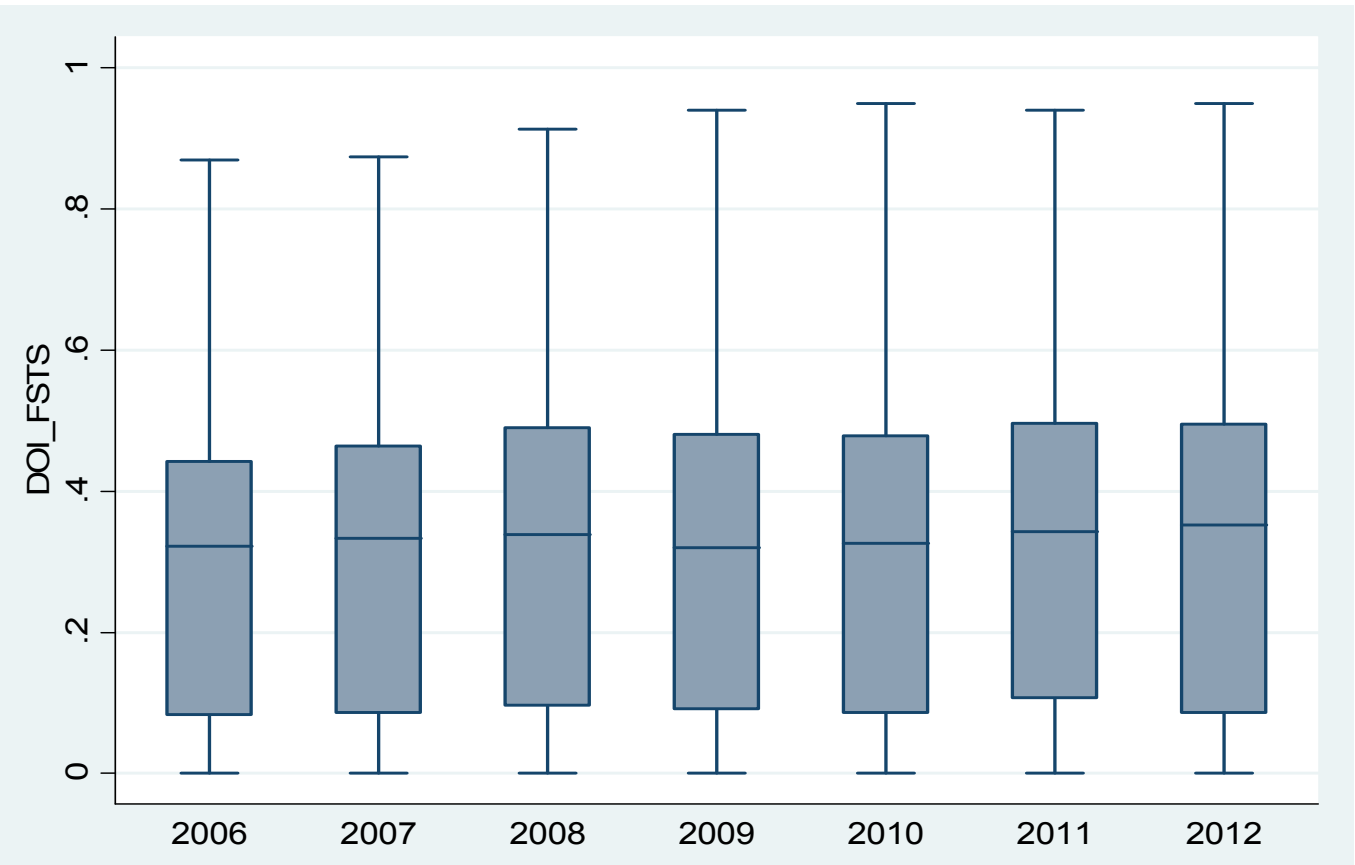


Figure 10. Box plot for sales growth per year.

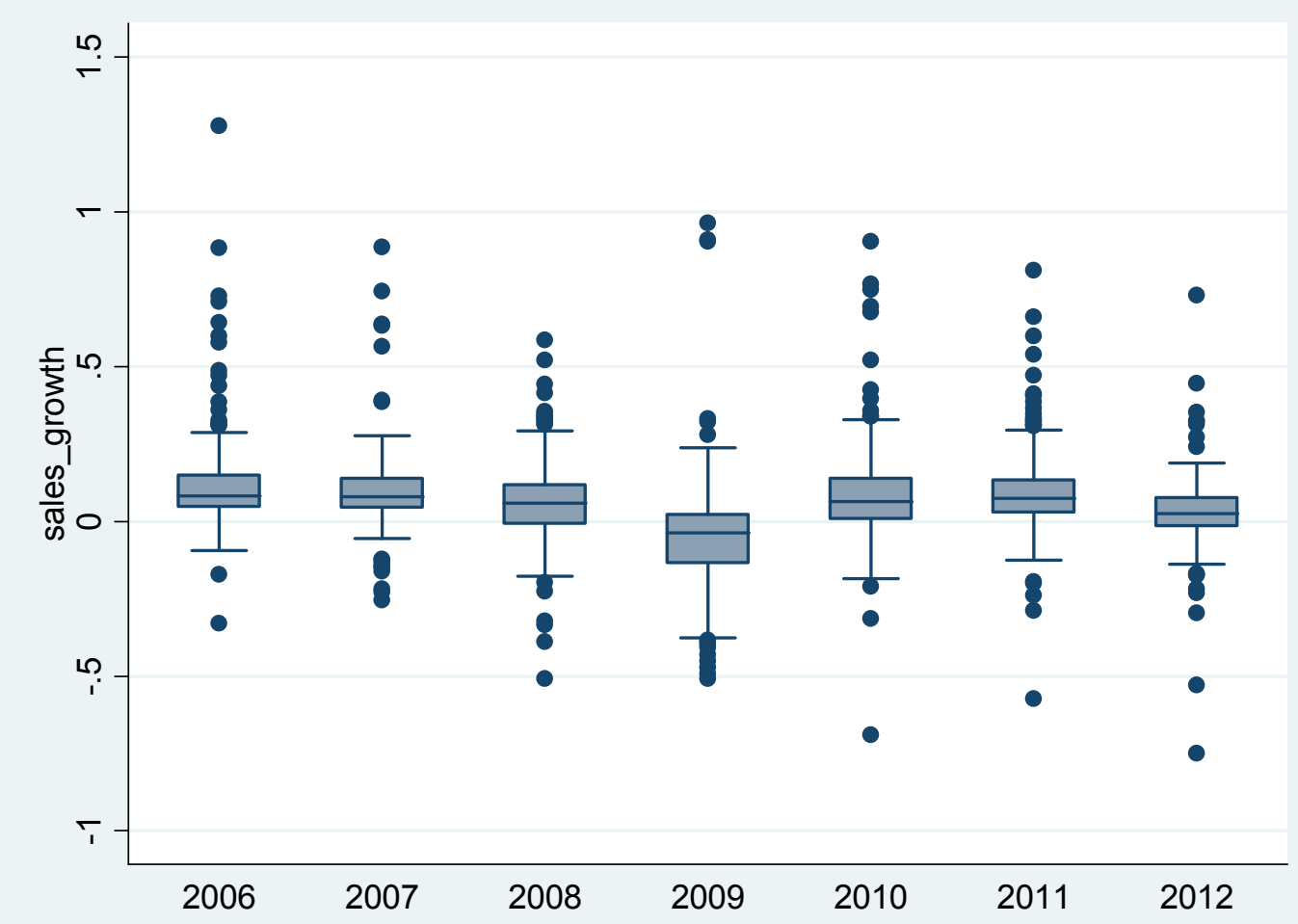

As depicted in the figures, there are outliers in the reputation scores for the lower levels. This might be explained by the industries that the firms belong. For example, firms with lower reputation scores (outliers in the low end) are Citigroup, Ford Motor Co., General Motors, Office Depot, Unisys, and Delta Airlines among the more salient. In the case of Ford, the lower values are found in 2009 and 2010; which we may attribute to the global financial crisis. GM's lowest score is found in 2011 which is the year after its filing for Chapter 11 (bankruptcy) and multiple closures of assembly lines in Michigan and Delaware. In the case of Delta Airlines, the worst years in terms of reputation are 2006 and 2007; it is not surprising as the company was under chapter 11 . However, it 
emerged from chapter 11 in April 2007 with great results after that. "Delta takes flight" was the title of one article in USNews in May 2007.

In the case of the box plots for DOI_FSTS, the results show more homogeneity among the firms throughout the years. For the last figure, sales growth results show variance among the firms. This is expected and required in dependent variables with respect to methodological aspects. There are outliers in the upper and lower ends of the box plot providing more variance to the dependent variable.

The following table shows the results for the correlation matrix for the main variables in 2006 and 2012. These variables are sales growth (dependent variable), reputation scores, number of employees, debt, acquisitions in the same country, the proposed degree of internationalization, the total distance from the firms' headquarters to top universities, and $R \& D$ expenses.

Table 17. Correlation matrix for the main variables in 2006.

\begin{tabular}{|l|c|c|c|c|c|c|c|}
\hline & 1 & 2 & 3 & 4 & 5 & 6 & 7 \\
\hline 1. sales_growth & 1 & & & & & & \\
\hline 2. mac_score & -0.05 & 1 & & & & & \\
\hline 3. employees & -0.07 & 0.08 & 1 & & & & \\
\hline 4. dlc & $0.23^{* * *}$ & -0.02 & $0.10+$ & 1 & & & \\
\hline 5. same_country & $0.15^{*}$ & $0.20^{* *}$ & -0.05 & $0.15^{*}$ & 1 & & \\
\hline 6. DOI_MJAV & $-0.12+$ & $0.12+$ & 0.03 & 0.04 & $0.21^{* *}$ & 1 & \\
\hline 7. totaldistance & $0.15^{*}$ & $0.12+$ & $-0.10+$ & $-0.11+$ & $0.13+$ & 0.08 & 1 \\
\hline 8. xrd Note: $* * *$ & $(\mathrm{p}$-value $<0.001) ; * *(\mathrm{p}$-value $<0.01) ; *(\mathrm{p}$-value $<0.05) ;+(\mathrm{p}$-value $<0.1)$ \\
\hline
\end{tabular}


Table 18. Correlation matrix for the main variables in 2012.

\begin{tabular}{|l|c|c|c|c|c|c|c|}
\hline & 1 & 2 & 3 & 4 & 5 & 6 & 7 \\
\hline 1. sales_growth & 1 & & & & & & \\
\hline 2. mac_score & $0.28^{* * *}$ & 1 & & & & & \\
\hline 3. employees & 0.00 & $0.11+$ & 1 & & & & \\
\hline 4. dlc & $-0.12+$ & -0.05 & 0.09 & 1 & & & \\
\hline 5. same_country & $0.14^{*}$ & $0.16^{*}$ & -0.06 & -0.02 & 1 & & \\
\hline 6. DOI_MJAV & -0.06 & $0.29^{* * *}$ & 0.02 & 0.03 & 0.05 & 1 & \\
\hline 7. totaldistance & 0.07 & $0.12+$ & -0.06 & -0.10 & $0.25^{* * *}$ & 0.08 & 1 \\
\hline 8. xrd & 0.03 & $0.15^{*}$ & 0.03 & 0.00 & $0.30^{* * *}$ & $0.35^{* * *}$ & $0.14^{*}$ \\
\hline
\end{tabular}

All the correlation coefficients are within the acceptable range of smaller than 0.3 in absolute values with the exception of the correlation between R\&D expenses ("xrd") and the proposed degree of internationalization ("DOI_MJAV"). In other words, firms which are more international spend more in $\mathrm{R} \& \mathrm{D}$. This phenomenon is not surprising as firms engaging in international expansion need to invest more resources for new product development, especially if the strategy for the expansion is market-seeking (Dunning, 1995); they need to have products appealing to foreign customers, or they need to adapt their current products to the local "taste" (the I-R framework) (Bartlett and Ghoshal, 1987).

The estimation method selected for this dissertation is the Arellano-Bond linear dynamic panel-data which is an appropriate methodology to analyze longitudinal panel data with several panels (211 firms) and few periods (7 years) (Arellano and Bond, 1991). The command in STATA v11 is "xtabond". Four control variables were added to all the hypotheses testing. The first one is the dummy variable for the global financial crisis years. The second is the firm age, which literature predicted some relevance for 
corporate reputation, and for innovation capability. According to Schumpeter, bigger and older firms tend to innovate more. Therefore, the third variable is firm size measured by the total assets in the company. Finally, the fourth control variable is the profitability of the company measured by the net income at year " $t$ ".

Testing hypothesis 1.

Hypothesis 1 argues that innovation capability expressed in R\&D expenses mediates the relationship between firm reputation and performance. In order to confirm the mediating effect, the methodologies by Baron and Kenny (1986) and MacKinnon et al. (2002) were followed as guidelines. In those studies, the authors explain the procedures to test for mediation. Basically the first step is to confirm the relationship between the predictor variable (firm reputation) and the response variable (firm performance). After, a relationship between the predictor variable (firm reputation) and the mediator variable (innovation capability) needs to be confirmed. Finally, the predictor and mediating variable need to be regressed on the outcome variable. Results of these three steps are shown in the figure below. The first step results are shown in the upper part of the figure. The firm reputation (mac_score) variable has been regressed with lag2 and lag3 with the outcome variable (sales_growth). Control variables are considered endogenous in the model. The xtabond command regresses endogenous variables with exogenous instrumental variables ( 45 in this case) to minimize the endogeneity problems. Results show a positive and significant relationship $(\mathrm{p}=0.014)$ between firm reputation at time $\mathrm{t}-3$ and firm performance at time $\mathrm{t}$. The second condition is shown in the middle part of the figure. Relationships between the predictor variable (lag 2 and lag3) and the mediating variable at time $t$ are confirmed $(\mathrm{p}=0.019$ and $\mathrm{p}=0.022$, respectively). Finally, 
the predictor and mediating variables are included together in the model. Results show that, indeed, there is evidence of a mediating effect. Lag3 of the firm reputation is positively and significant $(\mathrm{p}=0.002)$ related to the outcome variable at time $\mathrm{t}$ (sales_growth), and the lag2 of the innovation capability (R\&D expenses) is significantly $(p=0.038)$ related to the outcome variable at time $t$. Results confirmed the mediating effect of innovation on the relationship between firm reputation and performance in US firms, which is the main contribution of the dissertation.

Figure 11. Results for hypothesis 1.

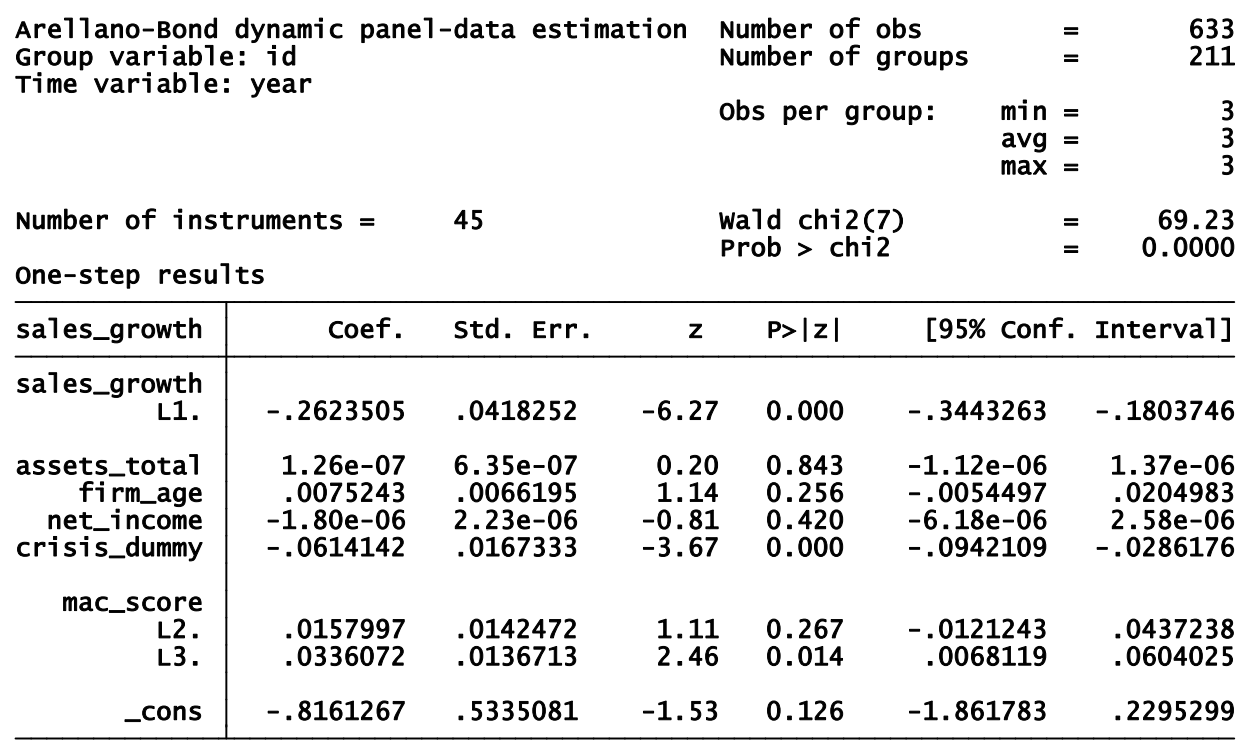




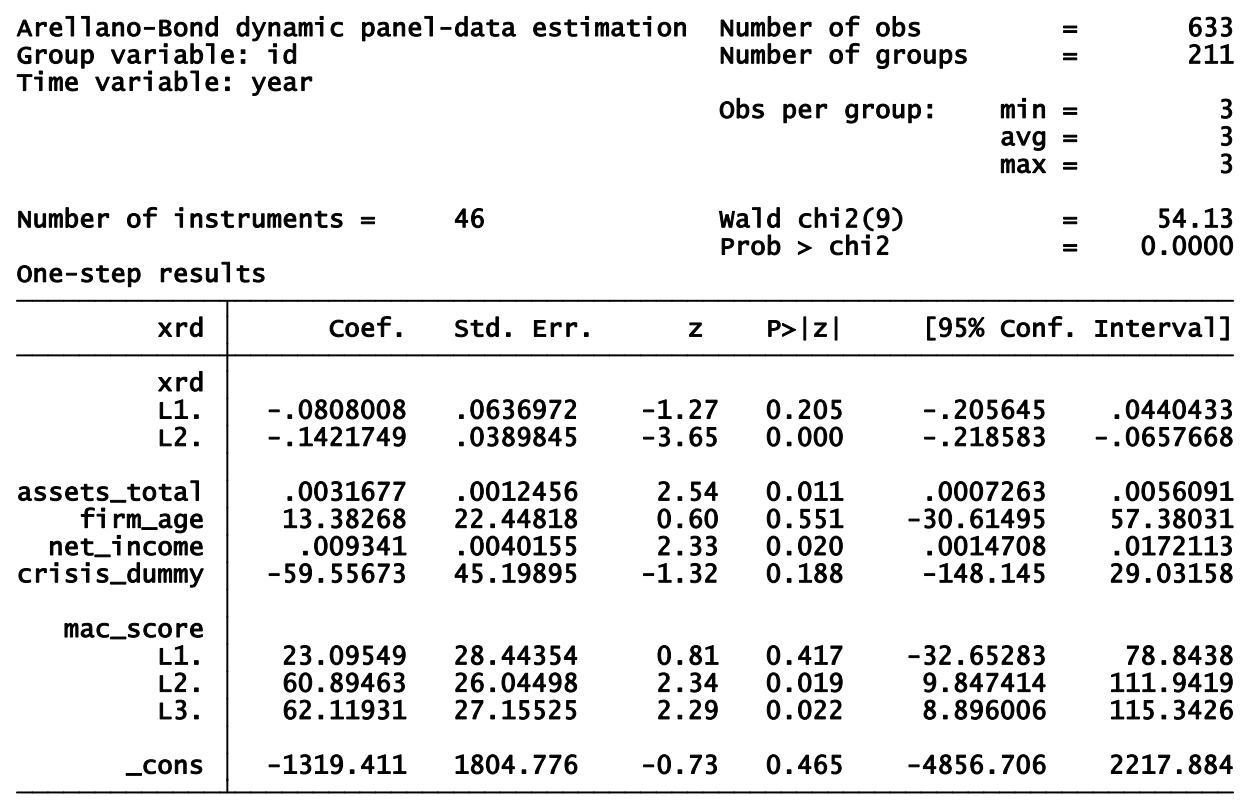

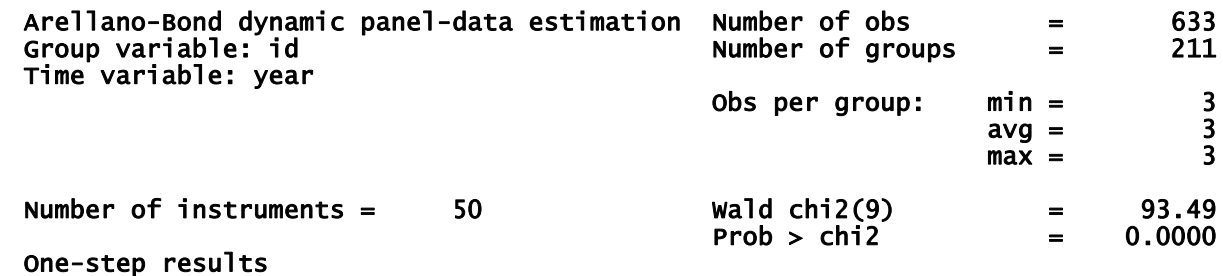

\begin{tabular}{|c|c|c|c|c|c|c|}
\hline sales_growth & coef. & std. Err. & z & $P>|z|$ & [95\% Conf. & Interval] \\
\hline $\begin{array}{r}\text { sales_growth } \\
\text { L1. }\end{array}$ & -.2678876 & .0451793 & -5.93 & 0.000 & -.3564375 & -.1793378 \\
\hline $\begin{array}{r}\text { assets_total } \\
\text { firm_age } \\
\text { net_income } \\
\text { crisis_dummy }\end{array}$ & $\begin{array}{r}6.40 \mathrm{e}-07 \\
.0086443 \\
1.92 \mathrm{e}-07 \\
-.0586748\end{array}$ & $\begin{array}{l}6.50 \mathrm{e}-07 \\
.0066684 \\
2.27 \mathrm{e}-06 \\
.0166681\end{array}$ & $\begin{array}{r}0.98 \\
1.30 \\
0.08 \\
-3.52\end{array}$ & $\begin{array}{l}0.325 \\
0.195 \\
0.933 \\
0.000\end{array}$ & $\begin{array}{l}-6.35 e-07 \\
-.0044256 \\
-4.25 e-06 \\
-.0913437\end{array}$ & $\begin{array}{r}1.92 \mathrm{e}-06 \\
.0217142 \\
4.63 \mathrm{e}-06 \\
-.0260059\end{array}$ \\
\hline $\begin{array}{l}\text { xrd } \\
--. \\
\text { L1. } \\
\text { L2. }\end{array}$ & $\begin{array}{r}-.0001525 \\
-.0000488 \\
.000096\end{array}$ & $\begin{array}{l}.0000424 \\
.0000419 \\
.0000463\end{array}$ & $\begin{array}{r}-3.60 \\
-1.16 \\
2.08\end{array}$ & $\begin{array}{l}0.000 \\
0.244 \\
0.038\end{array}$ & $\begin{array}{r}-.0002356 \\
-.0001309 \\
5.38 \mathrm{e}-06\end{array}$ & $\begin{array}{r}-.0000695 \\
.0000333 \\
.0001867\end{array}$ \\
\hline $\begin{array}{r}\text { mac_score } \\
\text { L3. }\end{array}$ & .0445121 & .0144308 & 3.08 & 0.002 & .0162282 & .0727959 \\
\hline _cons & -.8402965 & .5322994 & -1.58 & 0.114 & -1.883584 & .2029911 \\
\hline
\end{tabular}

It is worthwhile to mention that the mediating variable was included as an endogenous variable in the model. Instrumental variables (50) were used to minimize issues with endogeneity. Xtabond includes the instrumental variables by default when variables are included as endogenous in the model before the estimation process. 
Testing hypothesis 2 .

This hypothesis argues that the firm reputation score is positively related to the number of employees in subsequent years. In other words, high reputation attracts job applicants increasing the firm's applicants pool. As a result, the company may have more chances to select the "best" candidate for the position increasing the number of employees in the following years. The following figures report results obtained from hypothesis analyses.

Figure 12. Results for hypothesis 2.

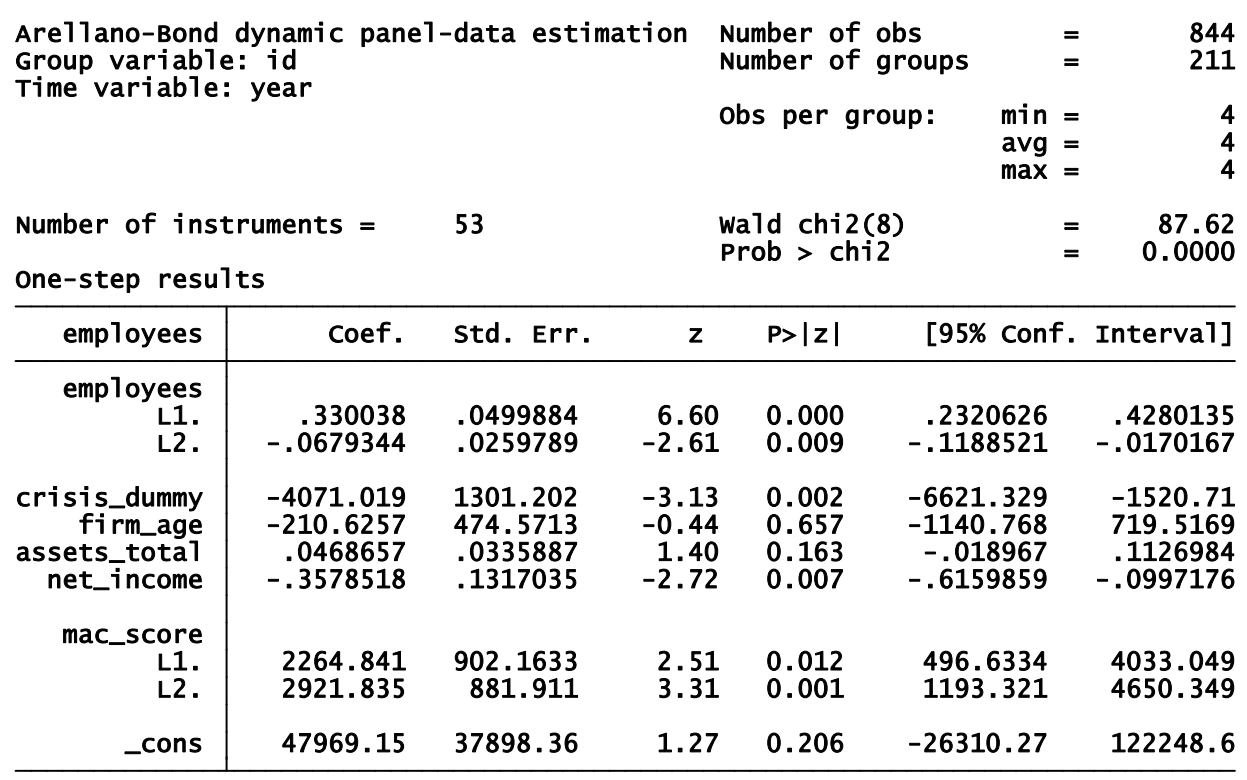

Correlation matrix of coefficients of xtabond mode1

\begin{tabular}{|c|c|c|c|c|c|c|c|c|}
\hline$e(v)$ & employ s. & $\underset{\text { employ s }}{\text { L2. }}$ & crisis y & firm_age & assets 1 & net_in e & mac_sc Le & mac_sc 2 e \\
\hline $\begin{array}{r}\text { L.employees } \\
\text { L2.employees } \\
\text { crisis_dummy } \\
\text { firm_age } \\
\text { assets_tota1 } \\
\text { net_income } \\
\text { L.mac_score } \\
\text { L2.mac_score } \\
\text { _cons }\end{array}$ & $\begin{array}{r}1.0000 \\
-0.5356 \\
-0.1002 \\
-0.0838 \\
-0.0820 \\
-0.1268 \\
-0.1086 \\
-0.0475 \\
0.0282\end{array}$ & $\begin{array}{r}1.0000 \\
0.0781 \\
0.0422 \\
-0.1286 \\
0.0941 \\
0.0167 \\
-0.0181 \\
-0.0301\end{array}$ & $\begin{array}{r}1.0000 \\
0.7666 \\
0.0429 \\
-0.0683 \\
-0.0477 \\
-0.1832 \\
-0.7099\end{array}$ & $\begin{array}{r}1.0000 \\
-0.2084 \\
-0.1076 \\
0.1574 \\
0.0862 \\
-0.9787\end{array}$ & $\begin{array}{r}1.0000 \\
-0.2598 \\
-0.0205 \\
-0.0497 \\
0.1534\end{array}$ & $\begin{array}{r}1.0000 \\
-0.0070 \\
-0.0224 \\
0.1285\end{array}$ & $\begin{array}{r}1.0000 \\
-0.1241 \\
-0.2670\end{array}$ & $\begin{array}{r}1.0000 \\
-0.1977\end{array}$ \\
\hline
\end{tabular}

Results show the positive relationship between reputation scores in $t-1(p=0.012)$ and $t-2(p=0.001)$ and the number of employees at time t. Results not only show the 
relationship exists, but also the causal relationship between these two variables. Results for the control variables are also consistent. For example, when the crisis_dummy variable is 1 , i.e. the year is part of the global financial crisis period of time, the number of employees is decreased. Firms tend to reduce the number of employees when such a difficult times arise. In the case of net income, if it goes up, then the number of employees is reduced. This can be explained due to the nature of the income. It is calculated by the total revenues minus all the costs before taxes. Considering the salaries of employees as a cost, it is logical to think that if the company reduces the number of employees, their costs will also be reduced; therefore, the net income will increase, ceteris paribus. Finally, the number of employees in previous years is also a significant predictor for the number of employees at time $t$.

In the correlation matrix for the results coefficients, we can observe acceptable values. All the values are below the accepted 0.3 in absolute terms except 4 correlations: the correlation between the constant and the crisis_dummy and firm_age which are not a major problem because it is the correlation with a constant. The correlation between lag1 and lag2 of the number of employees is normal since these variables are dependent on each other. Finally, the correlation between firm_age and crisis_dummy is high; however, these variables are control variables not affecting the results for the main variables. It is important to note that the control variables were included as endogenous variables and the reputation score as exogenous in the Arellano-Bond estimation process. This is important because each endogenous variable is evaluated using instrumental variables in order to control for endogeneity issues; the xtabond command performs the calculations with instrumental variables; in this case, it used 53 instrumental variables. Xtabond 
command does not directly provide variance inflation factor (VIF) values. I reran the model as if it were an OLS; this approach is more biased than the dynamic linear panel data estimation, but it provides a good sense of the VIFs and multicollinearity issues. The VIF values are below 3.3 for the lagged independent variable and 1.14 for the control variables. Since multicollinearity seems not present in the OLS regression, we can expect that it is also not an issue for the xtabond procedure as it increases the power in the model. In summary, these results support hypothesis 2 .

Testing hypothesis 3.

Hypothesis 3 suggests that the firm reputation score is positively related to the financial sources for innovation. Firms with higher reputation will find more "cheap" financial sources with less constraints and/or guarantees. As explained earlier, these financial sources are short and long term debts which are not related to equity or issuance of stock options for the loans. Control variables remain the same for the following models in order to make comparisons between different hypothesis testing models. The following figures report the results for this hypothesis. 
Figure 13. Results for hypothesis 3.

\begin{tabular}{|c|c|c|c|c|c|c|c|}
\hline $\begin{array}{l}\text { Are } 11 \text { ano-Bonc } \\
\text { Group variab }\end{array}$ & $\begin{array}{l}\text { namic pane } \\
\text { id }\end{array}$ & data est & on & $\begin{array}{ll}\text { mber } & 0 \\
\text { mber } & 0\end{array}$ & bups & $=$ & $\begin{array}{l}844 \\
211\end{array}$ \\
\hline & & & & s per & & $\begin{array}{l}\min = \\
\operatorname{avg}= \\
\max =\end{array}$ & \\
\hline $\begin{array}{l}\text { Number of ins } \\
\text { One-step rest }\end{array}$ & uments = & 53 & & $\begin{array}{l}\text { d chi } \\
b>c\end{array}$ & & & $\begin{array}{l}409.12 \\
0.0000\end{array}$ \\
\hline d1c & Coef. & Std. Err. & z & $P>|z|$ & {$[95$} & Conf. & Interval] \\
\hline $\begin{array}{l}\text { d1c } \\
\text { L1. } \\
\text { L2. }\end{array}$ & $\begin{array}{r}.3208917 \\
-.3396009\end{array}$ & $\begin{array}{r}02641 \\
.0251747\end{array}$ & $\begin{array}{r}12.15 \\
-13.49\end{array}$ & $\begin{array}{l}0.000 \\
0.000\end{array}$ & $\begin{array}{r}.26 \\
-.38\end{array}$ & $\begin{array}{l}1291 \\
9425\end{array}$ & $\begin{array}{r}.3726543 \\
-.2902593\end{array}$ \\
\hline $\begin{array}{r}\text { crisis_dummy } \\
\text { firm_age } \\
\text { assets_total } \\
\text { net_income }\end{array}$ & $\begin{array}{l}-2614.704 \\
-361.1218 \\
-.0902702 \\
-.4504539\end{array}$ & $\begin{array}{l}1043.695 \\
378.6962 \\
.0188443 \\
.0866868\end{array}$ & $\begin{array}{l}-2.51 \\
-0.95 \\
-4.79 \\
-5.20\end{array}$ & $\begin{array}{l}0.012 \\
0.340 \\
0.000 \\
0.000\end{array}$ & $\begin{array}{l}-466 \\
-110 \\
-.12 \\
-.62\end{array}$ & $\begin{array}{l}.309 \\
353 \\
2044 \\
3568\end{array}$ & $\begin{array}{r}-569.0981 \\
381.1091 \\
-.053336 \\
-.2805509\end{array}$ \\
\hline $\begin{array}{r}\text { mac_score } \\
\text { L1. } \\
\text { L2. }\end{array}$ & $\begin{array}{l}1345.986 \\
2807.301\end{array}$ & $\begin{array}{l}698.6258 \\
683.7139\end{array}$ & $\begin{array}{l}1.93 \\
4.11\end{array}$ & $\begin{array}{l}0.054 \\
0.000\end{array}$ & $\begin{array}{r}-23 . \\
146\end{array}$ & $\begin{array}{l}9573 \\
.246\end{array}$ & $\begin{array}{l}2715.267 \\
4147.355\end{array}$ \\
\hline _cons & 21256.93 & 30339.08 & 0.70 & 0.484 & -382 & 6.57 & 80720.42 \\
\hline
\end{tabular}

Correlation matrix of coefficients of xtabond mode1

\begin{tabular}{|c|c|c|c|c|c|c|c|c|}
\hline$e(v)$ & d7c & $\begin{array}{l}\text { L2. } \\
\text { d1c }\end{array}$ & crisis y & firm_age & assets 1 & net_in e & mac_sc e & $\underset{\text { mac_sc }}{\text { L2. }}$ \\
\hline $\begin{array}{r}\text { L.dlc } \\
\text { L2.dlc } \\
\text { crisis_dummy } \\
\text { firm_age } \\
\text { assets_total } \\
\text { net_income } \\
\text { L.mac_score } \\
\text { L2.mac_score } \\
\text { _cons }\end{array}$ & $\begin{array}{r}1.0000 \\
-0.2503 \\
-0.0191 \\
-0.0060 \\
0.0410 \\
0.0518 \\
-0.0273 \\
-0.0383 \\
0.0063\end{array}$ & $\begin{array}{r}1.0000 \\
-0.0576 \\
0.0089 \\
-0.1478 \\
0.0414 \\
0.0229 \\
0.0751 \\
-0.0205\end{array}$ & $\begin{array}{r}1.0000 \\
0.7925 \\
0.0196 \\
-0.0556 \\
-0.0462 \\
-0.2039 \\
-0.7348\end{array}$ & $\begin{array}{r}1.0000 \\
-0.1878 \\
-0.0836 \\
0.1505 \\
0.0529 \\
-0.9824\end{array}$ & $\begin{array}{r}1.0000 \\
-0.2270 \\
-0.0229 \\
-0.0973 \\
0.1458\end{array}$ & $\begin{array}{r}1.0000 \\
-0.0152 \\
0.0197 \\
0.0842\end{array}$ & $\begin{array}{r}1.0000 \\
-0.1312 \\
-0.2665\end{array}$ & $\begin{array}{r}1.0000 \\
-0.1663\end{array}$ \\
\hline
\end{tabular}

Results show that $\operatorname{lag} 1(\mathrm{p}=0.054)$ and $\operatorname{lag} 2(\mathrm{p}<0.001)$ for the firm reputation are good predictors for the short and long term debt ("dlc") for firms. Lag2 for reputation is strongly significant when predicting the debt at time t. These results suggest that banks and other financial institutions may base their lending decisions by observing the firms' past reputation scores, ceteris paribus. The correlation matrix for the coefficients also shows acceptable results. No other correlation pair is above 0.3 other than the constant with crisis_dummy, the constant with firm_age and the firm_age with crisis_dummy. The VIF values assuming OLS estimation show that the independent variable values are 
below 3.34 and below 4.05 for the control variables. Again, these results show no multicollinearity issues present in the model. Results support hypothesis 3 .

Testing hypothesis 4 .

Hypothesis 4 argues that firm reputation scores are positively related to the number of acquisitions achieved by a focal firm. Firms need to constantly search for new technologies and knowledge not only within the firm, but also outside firm boundaries. Information about the number of acquisitions (domestic and international) has been collected as well as the industry of such acquisitions (related vs unrelated). The ratio between domestic versus international acquisitions is $73 \%$ for the entire sample. In other words, US firms prefer domestic acquisitions in about $3 / 4$ of cases on average. The sample also shows that on average, US firms acquire companies in their same 2-digit SIC classification in $71 \%$ of cases providing information that US firms are acquiring related firms (low risk). The figures show the results for this hypothesis testing.

Figure 14. Results for hypothesis 4.

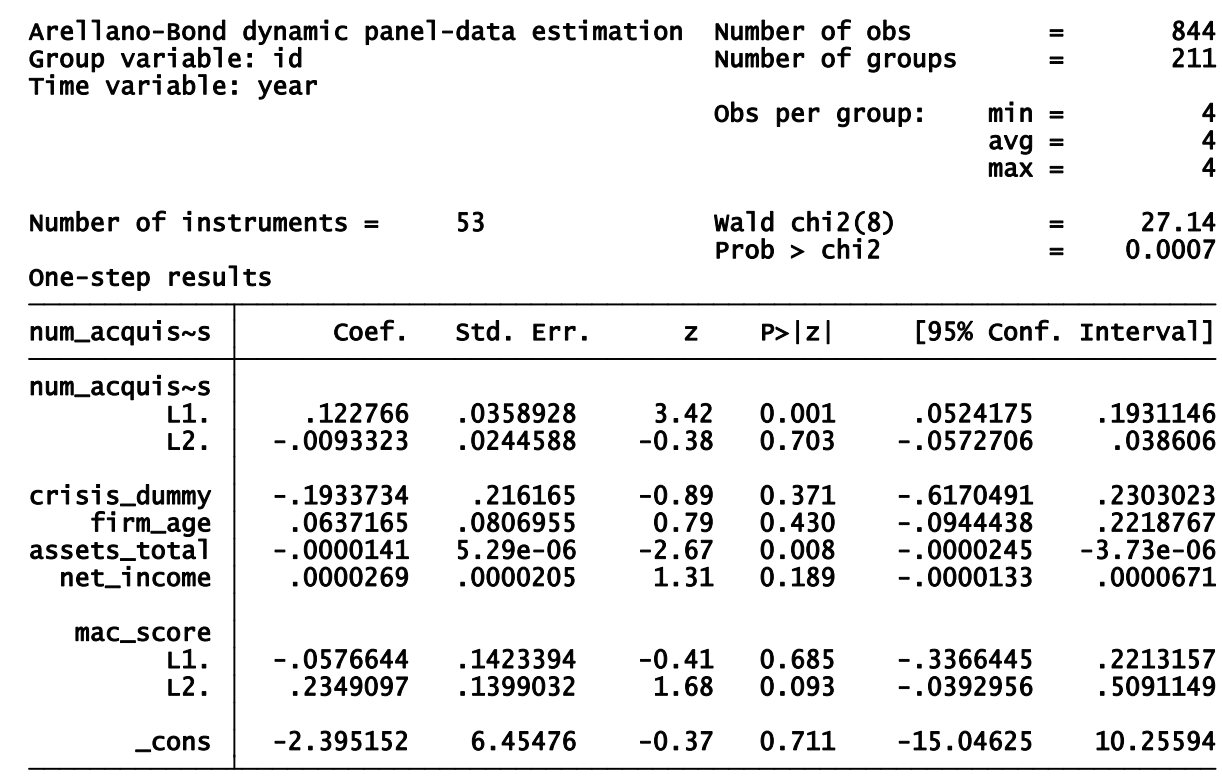




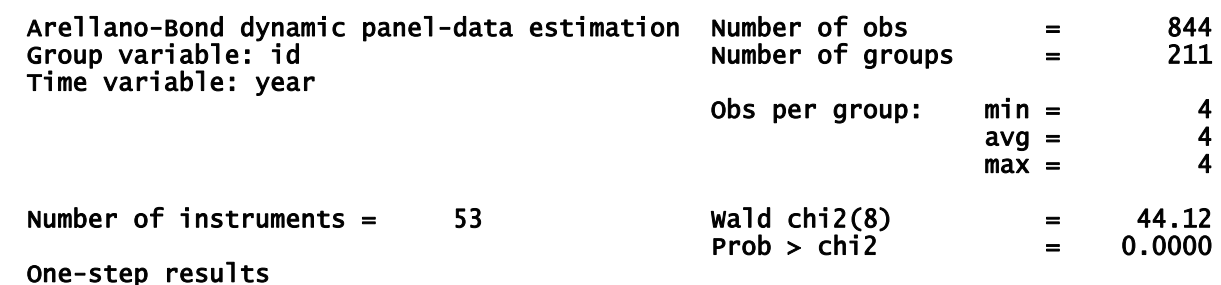

\begin{tabular}{r|rrrrrr}
\multicolumn{1}{l}{ One-step results } \\
\hline same_country & Coef. & std. Err. & $\mathrm{z}$ & $\mathrm{P}>|\mathrm{z}|$ & [95\% Conf. Interva1] \\
\hline same_country & & & & & & \\
L1. & .0233298 & .0383126 & 0.61 & 0.543 & -.0517614 & .0984211 \\
L2. & -.0876565 & .0239069 & -3.67 & 0.000 & -.1345131 & -.0407999 \\
crisis_dummy & -.3053304 & .1563433 & -1.95 & 0.051 & -.6117576 & .0010968 \\
firm_age & .0451684 & .0589822 & 0.77 & 0.444 & -.0704346 & .1607714 \\
assets_tota1 & -.0000165 & $3.83 e-06$ & -4.29 & 0.000 & -.000024 & $-8.94 \mathrm{e}-06$ \\
net_income & .0000148 & .0000143 & 1.03 & 0.301 & -.0000133 & .0000429 \\
mac_score & & & & & & \\
L1. & .1549137 & .1018413 & 1.52 & 0.128 & -.0446916 & .354519 \\
L2. & .2533476 & .1007159 & 2.52 & 0.012 & .0559481 & .4507471 \\
_cons & -2.568375 & 4.700904 & -0.55 & 0.585 & -11.78198 & 6.645227 \\
\hline
\end{tabular}

\begin{tabular}{|c|c|c|c|c|c|c|c|c|}
\hline$e(v)$ & same_c $\mathrm{L}$. & $\begin{array}{r}\text { L2. } \\
\text { same_c y }\end{array}$ & crisis y & firm_age & assets 1 & net_in e & mac_sc $e^{\mathrm{L}}$. & $\underset{\mathrm{mac} \text { L2 }}{\mathrm{LC} \text { e }}$ \\
\hline $\begin{array}{r}\text { L.same_cou y } \\
\text { L2.same_co y } \\
\text { crisis_dummy } \\
\text { firm_age } \\
\text { assets_total } \\
\text { net_income } \\
\text { L.mac_score } \\
\text { L2.mac_score } \\
\text { _cons }\end{array}$ & $\begin{array}{r}1.0000 \\
0.0641 \\
0.1760 \\
0.1746 \\
0.1557 \\
-0.0670 \\
-0.0531 \\
-0.0675 \\
-0.1791\end{array}$ & $\begin{array}{r}1.0000 \\
0.1697 \\
0.2725 \\
0.1641 \\
0.0357 \\
0.0041 \\
-0.0817 \\
-0.2756\end{array}$ & $\begin{array}{r}1.0000 \\
0.7937 \\
0.0659 \\
-0.0546 \\
-0.0533 \\
-0.2207 \\
-0.7464\end{array}$ & $\begin{array}{r}1.0000 \\
-0.1567 \\
-0.0711 \\
0.1392 \\
0.0165 \\
-0.9834\end{array}$ & $\begin{array}{r}1.0000 \\
-0.2683 \\
-0.0563 \\
-0.0720 \\
0.0955\end{array}$ & $\begin{array}{r}1.0000 \\
0.0028 \\
-0.0244 \\
0.0837\end{array}$ & $\begin{array}{r}1.0000 \\
-0.1313 \\
-0.2454\end{array}$ & $\begin{array}{r}1.0000 \\
-0.1233\end{array}$ \\
\hline
\end{tabular}

In the first part of the testing, I used the total number of acquisitions for the firm in a given year. The results show a marginal significance of the 2 year lagged reputation score in predicting num_acquisitons $(\mathrm{p}=0.093)$. However, as detailed before, there are more domestic acquisitions than international ones. Consequently, I decided to use the domestic acquisitions rather than the total number of acquisitions. In such case, the results are improved. The 2 year lagged effect of firm reputation is related and strongly significant $(\mathrm{p}=0.012)$ to the domestic acquisitions. As a result, domestic acquisitions are used as a proxy for knowledge and new technologies access for the rest of the dissertation and other analyses. The correlation matrix of the coefficients reports no apparent issues with high correlation between variables. Again, all the correlations are below 3.0 with the exception of firm_age and crisis_dummy, constant and firm_age, and constant and 
crisis_dummy. The VIF values assuming biased OLS results show that the values are less than 3.34 for the independent variable and less than 1.12 for the control variables. Accordingly, there are no major multicollinearity problems. Summarizing, results support hypothesis 4.

Testing hypothesis 5.

Hypothesis 5 suggests that the level of internationalization (DOI) of the firm interacts with the relationship between firm reputation scores and the number of employees such that for companies with higher level of DOI, the relationship is stronger. Thus, hypothesis 5 expects a positive interaction (multiplicative effect between reputation and DOI_MJAV). The proposed DOI measure takes into account the breadth and depth of internationalization as explained in Chapter II. Results are found in the following figure. Reputation scores, degree of internationalization and the multiplicative factor are assumed exogenous to the model as depicted in the conceptual model (see Chapter III). The control variables are assumed to be endogenous and the xtabond command utilizes instrumental variables in order to minimize the effect of endogeneity. For the hypotheses testing interaction effects, the variables were mean centered following Aiken and West (1991) recommendations. 
Figure 15. Results for hypothesis 5.

\begin{tabular}{|c|c|c|c|c|c|c|c|}
\hline \multirow{2}{*}{\multicolumn{4}{|c|}{$\begin{array}{l}\text { Arellano-Bond dynamic pane1-data estimation } \\
\text { Group variable: id } \\
\text { Time variable: year }\end{array}$}} & \multirow{2}{*}{\multicolumn{2}{|c|}{$\begin{array}{l}\text { Number of obs } \\
\text { Number of groups } \\
\text { Obs per group: }\end{array}$}} & \multirow{2}{*}{$\begin{aligned} & = \\
& = \\
\min & = \\
\operatorname{avg} & = \\
\max & =\end{aligned}$} & \multirow{3}{*}{$\begin{array}{r}844 \\
211 \\
4 \\
4 \\
4 \\
116.52 \\
0.0000\end{array}$} \\
\hline & & & & & & & \\
\hline $\begin{array}{l}\text { Number of ins } \\
\text { One-step rest }\end{array}$ & uments $=$ & 57 & & chi & & & \\
\hline employees & coef. & Std. Err. & $z$ & $P>|z|$ & {$[95 \%$} & Conf. & Interval] \\
\hline $\begin{array}{l}\text { emp1oyees } \\
\text { L1. } \\
\text { L2. }\end{array}$ & $\begin{array}{r}.3179703 \\
-.0727791\end{array}$ & $\begin{array}{l}.0506854 \\
.0259703\end{array}$ & $\begin{array}{r}6.27 \\
-2.80\end{array}$ & $\begin{array}{l}0.000 \\
0.005\end{array}$ & $\begin{array}{r}.2186 \\
-.1236\end{array}$ & $\begin{array}{l}6288 \\
6799\end{array}$ & $\begin{array}{r}.4173118 \\
-.0218784\end{array}$ \\
\hline $\begin{array}{r}\text { crisis_dummy } \\
\text { firm_age } \\
\text { assets_tota1 } \\
\text { net_income }\end{array}$ & $\begin{array}{r}-2357.371 \\
-576.0043 \\
.0684858 \\
-.3722324\end{array}$ & $\begin{array}{l}1284.151 \\
460.7993 \\
.0333251 \\
.1316988\end{array}$ & $\begin{array}{r}-1.84 \\
-1.25 \\
2.06 \\
-2.83\end{array}$ & $\begin{array}{l}0.066 \\
0.211 \\
0.040 \\
0.005\end{array}$ & $\begin{array}{r}-4874 \\
-1479 \\
.0031 \\
-.6303\end{array}$ & $\begin{array}{l}4.26 \\
.154 \\
1698 \\
3572\end{array}$ & $\begin{array}{r}159.5178 \\
327.1458 \\
.1338017 \\
-.1141076\end{array}$ \\
\hline $\begin{array}{r}\text { c_mac_score } \\
\text { L1. } \\
\text { L2. }\end{array}$ & $\begin{array}{l}1505.895 \\
3451.545\end{array}$ & $\begin{array}{l}953.0171 \\
892.6624\end{array}$ & $\begin{array}{l}1.58 \\
3.87\end{array}$ & $\begin{array}{l}0.114 \\
0.000\end{array}$ & $\begin{array}{r}-361.9 \\
1701 .\end{array}$ & $\begin{array}{l}9846 \\
.958\end{array}$ & $\begin{array}{l}3373.774 \\
5201.131\end{array}$ \\
\hline $\begin{array}{r}\text { C_DOI_MJAV } \\
\text { L1. } \\
\text { L2 }\end{array}$ & $\begin{array}{r}171.041 \\
-162.6173\end{array}$ & $\begin{array}{l}383.8036 \\
334.2207\end{array}$ & $\begin{array}{r}0.45 \\
-0.49\end{array}$ & $\begin{array}{l}0.656 \\
0.627\end{array}$ & $\begin{array}{l}-581 \\
-817\end{array}$ & $\begin{array}{l}2003 \\
6778\end{array}$ & $\begin{array}{l}923.2823 \\
492.4433\end{array}$ \\
\hline $\begin{array}{r}\text { C_mac_scor } \sim V \\
\text { L1. } \\
\text { L2 }\end{array}$ & $\begin{array}{l}508.9728 \\
458.1833\end{array}$ & $\begin{array}{r}159.92 \\
164.4854\end{array}$ & $\begin{array}{l}3.18 \\
2.79\end{array}$ & $\begin{array}{l}0.001 \\
0.005\end{array}$ & $\begin{array}{l}195 \\
135\end{array}$ & $\begin{array}{l}5353 \\
7978\end{array}$ & $\begin{array}{l}822.4103 \\
780.5688\end{array}$ \\
\hline _cons & 106539.7 & 35100.05 & 3.04 & 0.002 & 377 & 4.88 & 175334.6 \\
\hline
\end{tabular}

Correlation matrix of coefficients of xtabond model

\begin{tabular}{|c|c|c|c|c|c|c|c|c|}
\hline$e(v)$ & employ s. & $\begin{array}{r}\mathrm{L2} . \\
\text { employ s }\end{array}$ & crisis y & firm_age & assets 1 & net_in e & c_mac_ Le & c_mac_ 2 e \\
\hline $\begin{array}{r}\text { L.employees } \\
\text { L2.employees } \\
\text { crisis_dummy } \\
\text { firm_age } \\
\text { assets_tota1 } \\
\text { net_income } \\
\text { L.C_mac_sC e } \\
\text { L2.c_mac_s e } \\
\text { L.C_DOI_MJAV } \\
\text { L2.C_DOI_M V } \\
\text { L.C_mac_SC V } \\
\text { L2.c_mac_s V } \\
\text { _cons }\end{array}$ & $\begin{array}{r}1.0000 \\
-0.5275 \\
-0.1389 \\
-0.0649 \\
-0.1074 \\
-0.1298 \\
-0.1018 \\
-0.0613 \\
0.0474 \\
0.0346 \\
0.0699 \\
-0.2215 \\
-0.0151\end{array}$ & $\begin{array}{r}1.0000 \\
0.0739 \\
0.0359 \\
-0.1167 \\
0.0973 \\
-0.0101 \\
-0.0040 \\
0.0138 \\
0.0037 \\
-0.0598 \\
0.0402 \\
-0.0261\end{array}$ & $\begin{array}{r}1.0000 \\
0.8215 \\
0.0548 \\
-0.0730 \\
-0.0339 \\
0.0524 \\
-0.0035 \\
-0.0348 \\
0.0609 \\
0.1355 \\
-0.8315\end{array}$ & $\begin{array}{r}1.0000 \\
-0.1825 \\
-0.1039 \\
-0.0345 \\
0.0720 \\
-0.0231 \\
-0.0162 \\
0.0383 \\
0.0458 \\
-0.9930\end{array}$ & $\begin{array}{r}1.0000 \\
-0.2608 \\
-0.0215 \\
-0.0497 \\
0.0786 \\
-0.0419 \\
-0.0603 \\
0.0834 \\
0.1252\end{array}$ & $\begin{array}{r}1.0000 \\
-0.0012 \\
-0.0147 \\
-0.0318 \\
0.0235 \\
-0.0763 \\
0.0282 \\
0.1276\end{array}$ & $\begin{array}{r}1.0000 \\
-0.1640 \\
-0.0347 \\
0.0005 \\
0.0315 \\
-0.0049 \\
0.0502\end{array}$ & $\begin{array}{r}1.0000 \\
-0.0089 \\
-0.0381 \\
0.0005 \\
0.0399 \\
-0.0610\end{array}$ \\
\hline$e(v)$ & C_DOI_ L V & C_DOI_ V & c_mac_ $L$ V & c_mac_ 2 V & _cons & & & \\
\hline $\begin{array}{r}\text { L.C_DOI_MJAV } \\
\text { L2.c_DOI_M V } \\
\text { L.C_mac_sC V } \\
\text { L2.c_mac_s V V } \\
\text { _cons }\end{array}$ & $\begin{array}{r}1.0000 \\
-0.3980 \\
-0.0511 \\
0.0331 \\
0.0104\end{array}$ & $\begin{array}{r}1.0000 \\
0.0116 \\
-0.1686 \\
0.0159\end{array}$ & $\begin{array}{r}1.0000 \\
-0.1484 \\
-0.0425\end{array}$ & $\begin{array}{r}1.0000 \\
-0.0328\end{array}$ & 1.0000 & & & \\
\hline
\end{tabular}

Results show that the multiplicative effects (lagged 1 and 2 years) are positive and strongly significant $(p=0.001$ and $p=0.005$ ) to the relationship between reputation and the number of employees. The direct effect of the reputation (2 year lagged mean centered) 
remains positive and significant after including the interaction effect. However, the coefficients for the DOI_MJAV (lag 1 and lag2 mean centered) became insignificant $(p=0.656$ and $p=0.627)$. In testing interactions, what really matters is the sign and significance of the interaction effect, which is positive as expected in the hypothesis. The correlation matrix of the coefficients seems acceptable. All the correlations are below 3.0 except the lag 1 and 2 year for employees; it is logical that the number of employees from the previous year is correlated with the number of employees in time $t+1$. Firm_age and crisis_dummy are correlated, as well as constant and crisis_dummy, constant and firm_age, and lag2_c_DOI_MJAV and lag1_c_DOI_MJAV which is expected as firms do not radically change their degree of internationalization from one year to another. In summary, the results support hypothesis 5 . The internationalization level of a firm, indeed, strengthens the relationship between corporate reputation and the number of employees.

Testing hypothesis 6.

Hypothesis 6 suggests that the degree of internationalization (DOI_MJAV) has a positive interaction effect on the relationship between corporate reputation and short and long term debt such that firms with higher levels of internationalization will show stronger relationships. Firm reputation, degree of internationalization, and the interaction effect are considered exogenous to the model and were mean centered before calculating the multiplicative term. The results are shown below. 
Figure 16. Results for hypothesis 6.

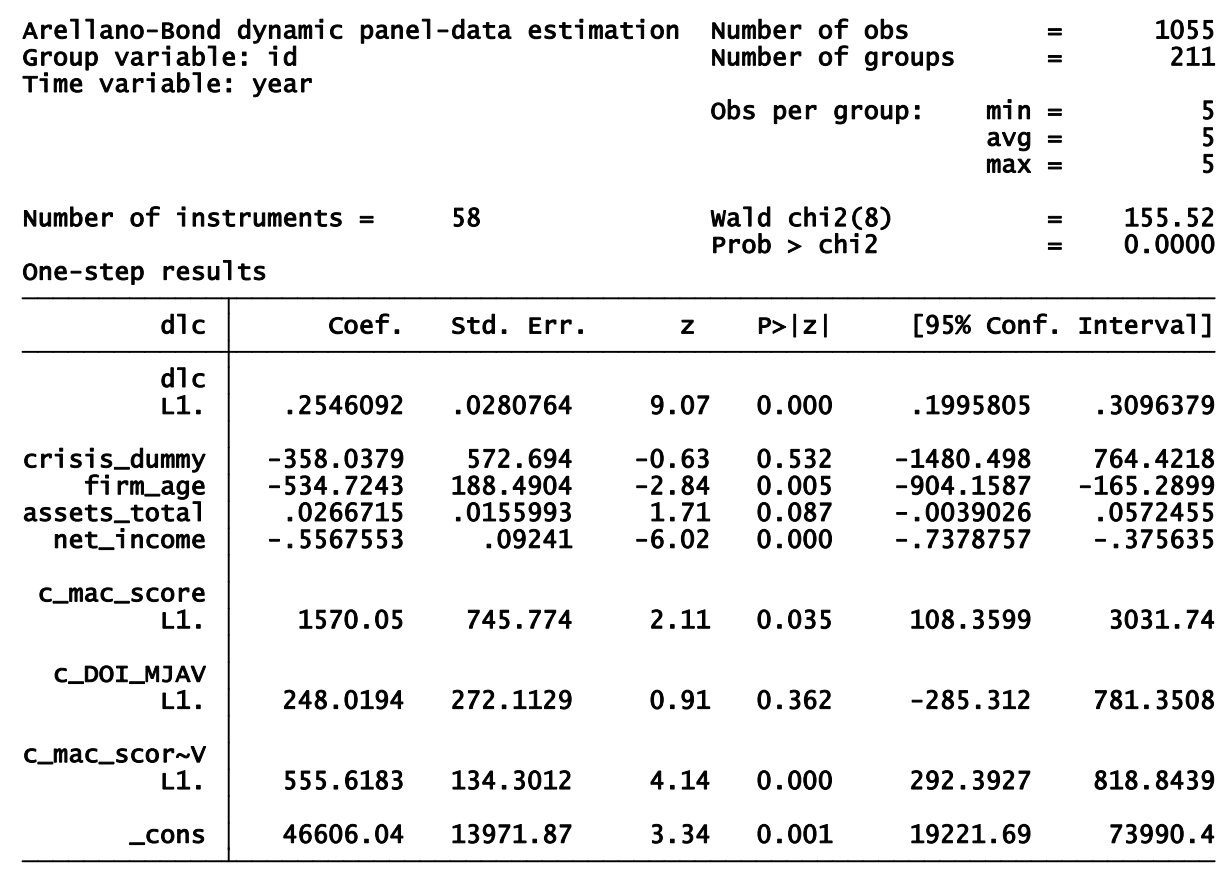

Results support hypothesis 6 . The interaction effect is positive and strongly significant $(\mathrm{p}=0.000)$ for the model. Also, lag1 for reputation (mean centered) remains significant $(\mathrm{p}=0.035)$. Lag1 for the direct effect of DOI_MJAV (mean centered) is not significant ( $\mathrm{p}=0.362)$; however, when testing interaction effects, the direction and significance of the multiplicative factor are the main objectives. Thus, firms with higher levels of internationalization may have better and more sources for financing their new product development or innovation projects as the interaction effect is positive and significant.

Testing hypothesis 7.

Hypothesis 7 argues that the degree of internationalization (DOI_MJAV) has an interaction effect on the relationship between corporate reputation and the number of acquisitions such that the relationship is stronger for firms with higher levels of 
internationalization. In hypothesis 4 , it has been shown that domestic acquisitions are used instead of the total number of acquisitions performed by the focal firm because US firms on average make more domestic and related acquisitions than the opposite.

International experience measured by the degree of internationalization may influence the firms to engage in domestic acquisitions because they experienced the difficulties and costs of doing business abroad. Accordingly, we expect to find a positive coefficient for the multiplicative term in the dynamic linear panel data estimation. Direct factors were mean centered by year before calculating the multiplicative factor.

Figure 17. Results for hypothesis 7.

\begin{tabular}{|c|c|c|c|c|c|c|c|}
\hline \multicolumn{4}{|c|}{$\begin{array}{l}\text { Arellano-Bond dynamic pane1-data estimation } \\
\text { Group variable: id } \\
\text { Time variable: year }\end{array}$} & \multirow{2}{*}{\multicolumn{2}{|c|}{$\begin{array}{l}\text { Number of obs } \\
\text { Number of groups } \\
\text { obs per group: }\end{array}$}} & \multirow{2}{*}{$\begin{aligned} & = \\
& = \\
\min & = \\
\operatorname{avg} & = \\
\max & =\end{aligned}$} & \multirow{3}{*}{$\begin{array}{r}= \\
=\quad 244 \\
: \quad \\
: \quad 4 \\
4 \\
=\quad 0.0000\end{array}$} \\
\hline & & & & & & & \\
\hline \multicolumn{2}{|c|}{$\begin{array}{l}\text { Number of instruments }= \\
\text { One-step results }\end{array}$} & 54 & \multicolumn{3}{|c|}{$\begin{array}{l}\text { wald chi2(9) } \\
\text { Prob > chi2 }\end{array}$} & & \\
\hline same_country & coef. & Std. Err. & z & $P>|z|$ & {$[95$} & Conf. & Interval] \\
\hline $\begin{array}{r}\text { same_country } \\
\text { L1. } \\
\text { L2. }\end{array}$ & $\begin{array}{r}.026654 \\
-.0844322\end{array}$ & $\begin{array}{l}.0388935 \\
.0242624\end{array}$ & $\begin{array}{r}0.69 \\
-3.48\end{array}$ & $\begin{array}{l}0.493 \\
0.001\end{array}$ & $\begin{array}{l}-.0 \\
-.1\end{array}$ & $\begin{array}{l}5759 \\
9857\end{array}$ & $\begin{array}{r}.1028839 \\
-.0368788\end{array}$ \\
\hline $\begin{array}{r}\text { crisis_dummy } \\
\text { firm_age } \\
\text { assets_tota1 } \\
\text { net_income }\end{array}$ & $\begin{array}{r}-.1832263 \\
.0182002 \\
-.0000151 \\
.0000124\end{array}$ & $\begin{array}{l}.1524223 \\
.0584167 \\
3.86 \mathrm{e}-06 \\
.0000143\end{array}$ & $\begin{array}{r}-1.20 \\
0.31 \\
-3.90 \\
0.87\end{array}$ & $\begin{array}{l}0.229 \\
0.755 \\
0.000 \\
0.386\end{array}$ & $\begin{array}{l}-.48 \\
-.09 \\
-.00 \\
-.00\end{array}$ & $\begin{array}{l}9687 \\
2945 \\
0227 \\
0156\end{array}$ & $\begin{array}{r}.115516 \\
.1326949 \\
-7.50 \mathrm{e}-06 \\
.0000403\end{array}$ \\
\hline $\begin{array}{r}\text { c_mac_score } \\
\text { L2 } .\end{array}$ & .2651997 & .1055553 & 2.51 & 0.012 & .05 & 3151 & .4720844 \\
\hline $\begin{array}{l}\text { C_DOI_MJAV } \\
\text { L2 . }\end{array}$ & -.0355091 & .0379625 & -0.94 & 0.350 & -.10 & 9141 & .038896 \\
\hline $\begin{array}{r}\text { c_mac_scor } 2 \text { V } \\
\text { L2 . }\end{array}$ & .0476976 & .0191693 & 2.49 & 0.013 & .010 & 1264 & .0852688 \\
\hline _cons & 1.841578 & 4.504188 & 0.41 & 0.683 & -6.98 & 6469 & 10.66963 \\
\hline
\end{tabular}

As expected, the coefficient for the interaction, or multiplicative, term is positive and significant $(\mathrm{p}=0.013)$. Also, the direction and significance for the direct effect of the lag2 for mean centered corporate reputation (c_mac_score) remains positive and significant $(\mathrm{p}=0.012)$. The mean centered variable for internationalization 
(c_DOI_MJAV) is not significant $(\mathrm{p}=0.350)$. However, Aiken and West (1991 pg. 11)

attests that interaction (or moderating) effects are found when the coefficient for the multiplicative term is significant. The significances for the direct effects are not required to remain significant for concluding the presence of an interaction effect in the model. Therefore, results confirm and support hypothesis 7 .

Testing hypothesis 8 .

Hypothesis 8 argues that the distance of firms' headquarters to top ranked universities measured in Euclidean distance has an interaction effect on the relationship between firm reputation and the number of employees. In other words, the closer the firms are to those educational institutions, the stronger the relationship between reputation and the number of employees. As the distance is measured by the total miles from the firms HQ to the universities, proximity is, then, the inverted (negative) of the number of miles which are found in the "totaldistance". I then created the variables "c_minus_totaldistance" and "c_mac_scoreXc_minus_totaldist" to represent the closeness or proximity to the universities which was mean centered before calculating the multiplicative term. In this model, reputation scores, proximity to the universities, and the interaction effect are exogenous; the rest of variables are considered endogenous. "c_minus_totaldistance" in assumed to be invariant during the time span of the study as it is assumed that the top ranked universities in the fields of engineering, marketing, and entrepreneurship do not suffer radical changes in their positions within more or less 5 years. However, the multiplicative effect is time variant. Results are depicted below. 
Figure 18. Results for hypothesis 8.

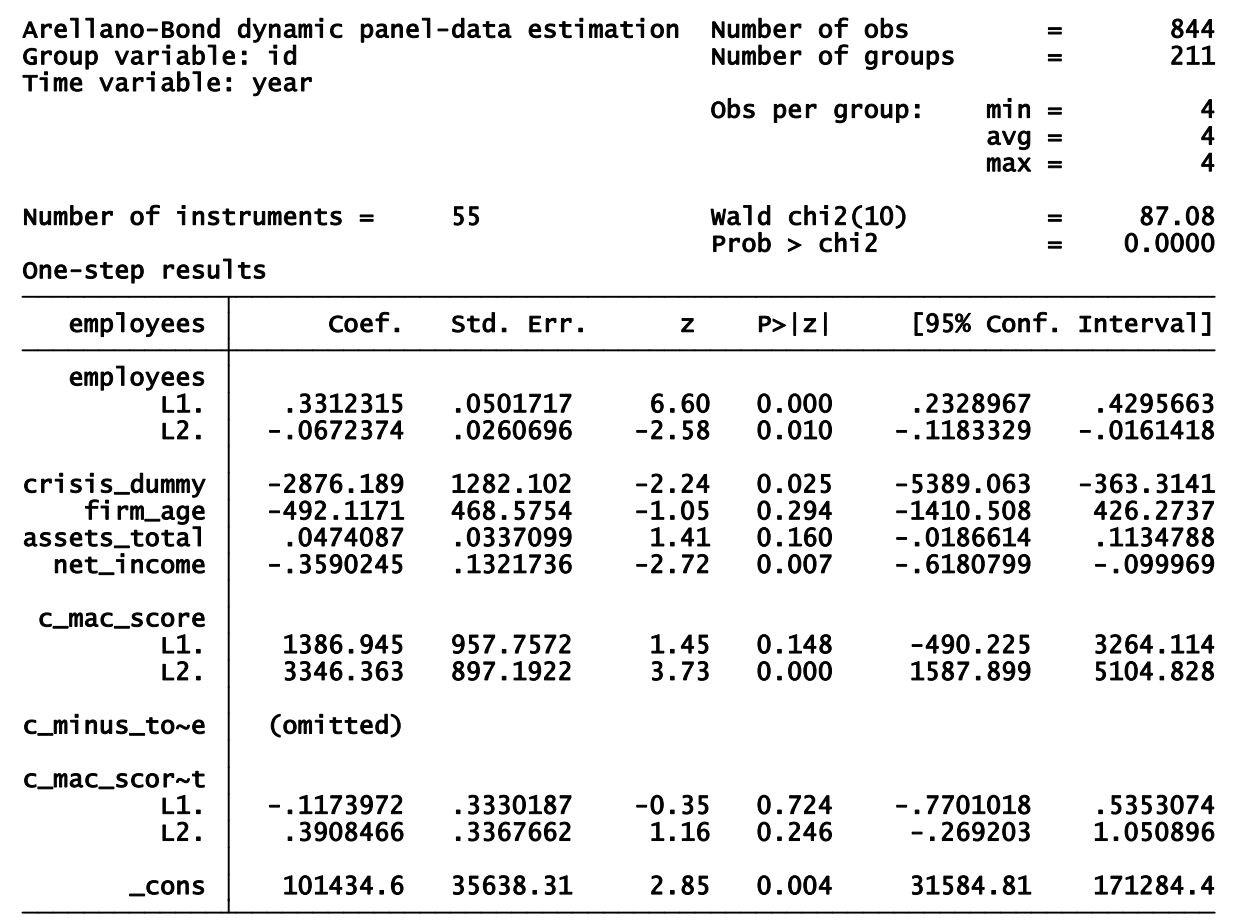

Results show that the lag2 for the reputation direct effect (mean centered) remains positive and significant $(\mathrm{p}=0.000)$ and the lag2 for the interaction effect is positive as expected, but not significant $(\mathrm{p}=0.246)$. The direct effect of c_minus_totaldistance is dropped from the analysis due to multicollinearity; as this variable is time invariant, xtabond procedure dropped it from the estimation. As a result, the hypothesis 8 is not supported. As a next step, I added the 2 interaction effects for the number of employees in the same model, i.e. the degree of internationalization and the proximity to universities. Results are shown next. 
Figure 19. Results for 2 interaction effects.

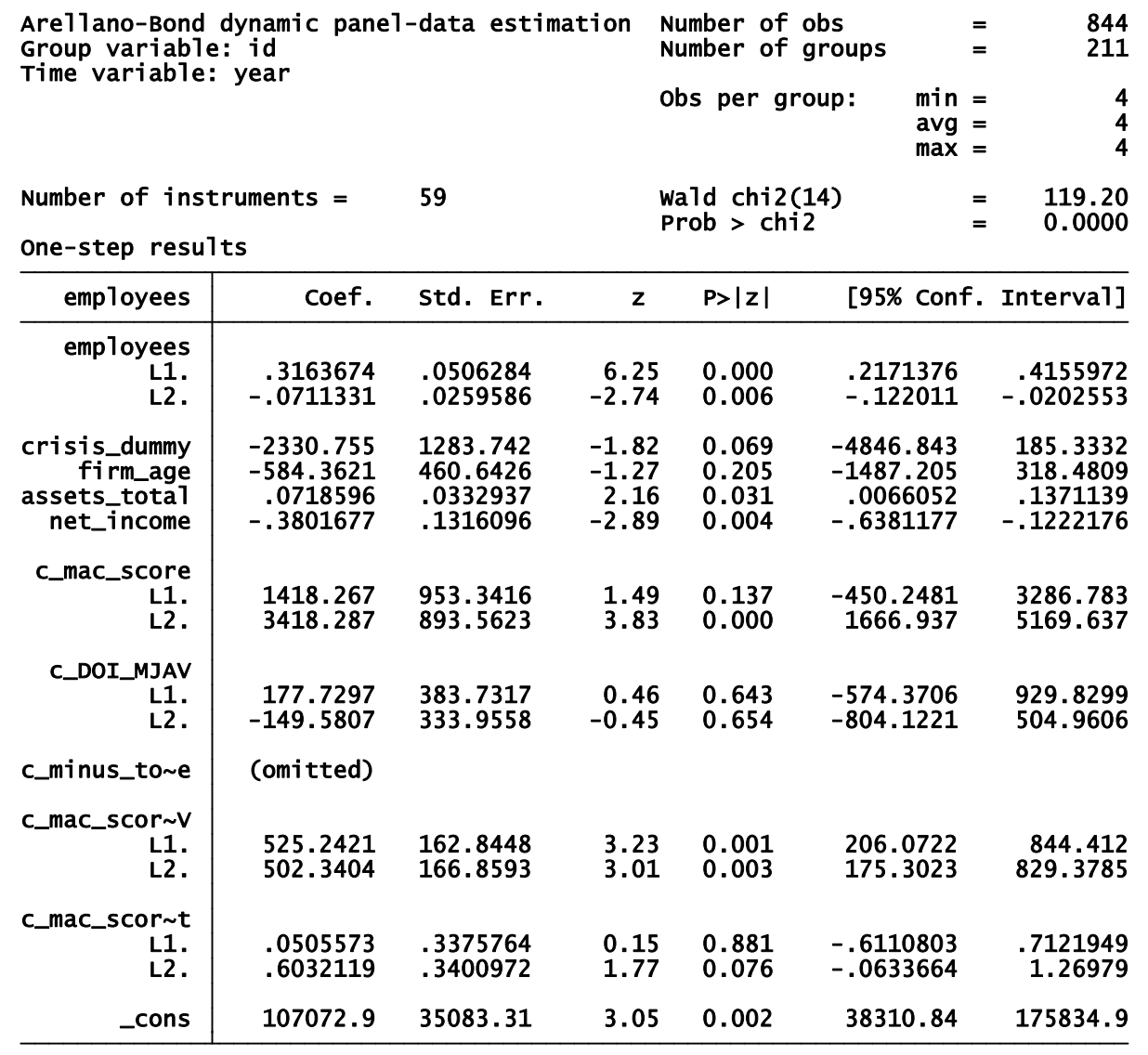

Results remain robust with the inclusion of 2 interaction effects. The interaction effect for c_DOI_MJAV remains positive and significant $(\mathrm{p}=0.001$ for lag 1 and $\mathrm{p}=0.003$ for lag2) while the interaction effect for the proximity remains positive, but marginally significant ( $\mathrm{p}=0.076$ for lag2). Noticeably, the direct effect of corporate reputation (mean centered) remains strongly significant ( $p=0.000$ for lag2) after the inclusion of 2 interaction factors with their respective direct effects. The model is robust to different testing modifications.

Testing hypothesis 9.

Hypothesis 9 suggests that the number of employees (human capital for innovation) is positively related to the $R \& D$ expenses (innovation capability). In this 
model, the predictors and control variables are assumed to be endogenous because the predictor (employees) is explained by the reputation score variable which is exogenous to the model. The results are shown below.

Figure 20. Results for hypothesis 9.

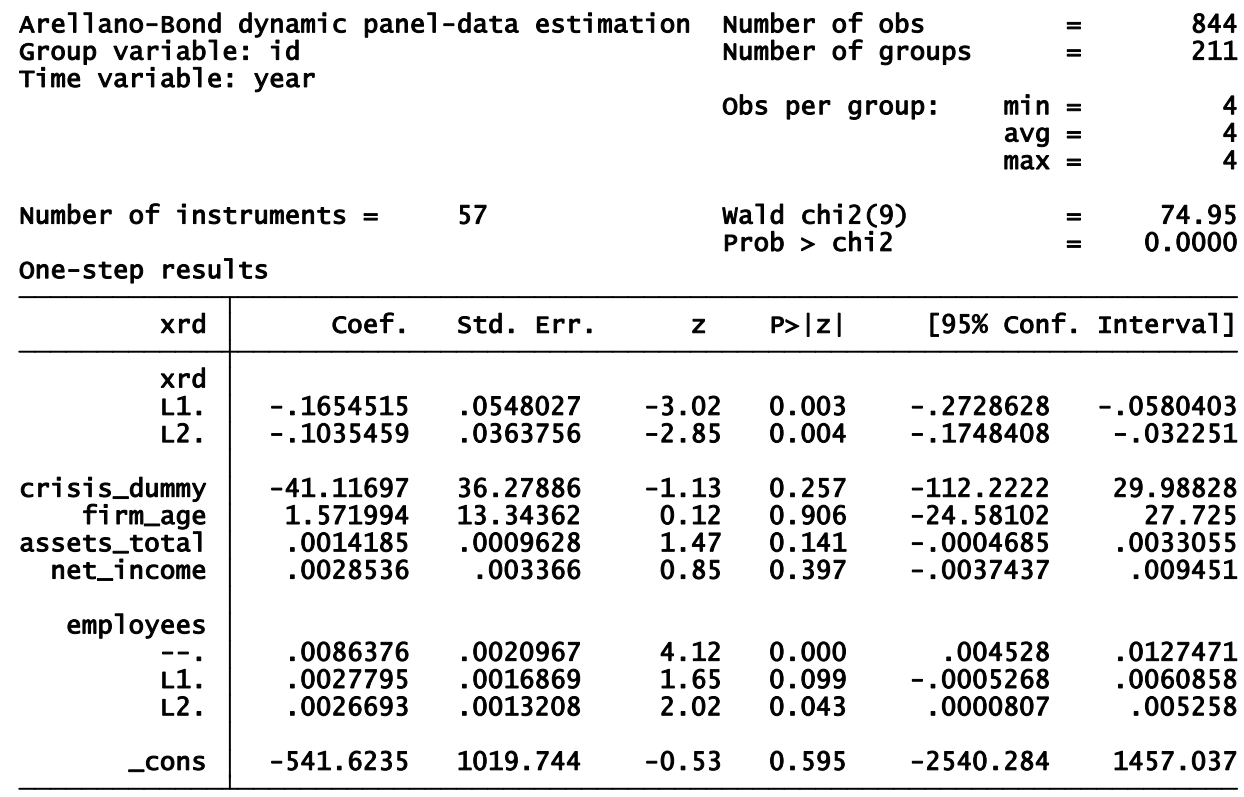

Results show that human capital is positively related to the R\&D expenses in following years. In fact, employees at $\mathrm{t}-2$ is significantly related $(\mathrm{p}=0.043)$ to the $\mathrm{R} \& \mathrm{D}$ expenses at time $t$; while employees at time $\mathrm{t}-1$ is marginally significant $(\mathrm{p}=0.099)$. Although "employees" at time $t$ is strongly significant, the interpretation is not functional other than the statistical meaning. The xtabond command provides the coefficient of the endogenous variable at time $t$ and its lagged effects as default. Thus, results support hypothesis 9 . One step further in the analysis of hypothesis 9 is to include the exogenous effect of firm reputation as a predictor; in other words, hypothesis 9 can test the mediating effect of employees on the relationship between reputation and R\&D expenses; i.e. reputation predicting human capital $(\mathrm{H} 2)$ predicting innovation capability. The results 
of this analysis are listed below. For this analysis, corporate reputation needs to be lagged at least one more period in the past and "employees" need to be lagged for only one period of time to represent causality. However, note that this procedure reduces the number of observations to 633 or 3 groups of 211 firms. Results show a fully mediating effect between corporate reputation, employees, and R\&D expenses. Following Baron and Kenny (1986) and MacKinnon et al., (2002) studies, results show a significant relationship between corporate reputation and R\&D expenses (see figure 21). There, lag2 and lag3 of corporate reputation are significantly ( $\mathrm{p}=0.017$ and $\mathrm{p}=0.024$, respectively) related to $R \& D$ expenses at time $t$. Then, hypothesis 2 confirmed the positive and strong relationship between corporate reputation and the number of employees. Finally, the results with both direct effects show a positive and significant relationship $(\mathrm{p}=0.045)$ between lag1 employees and $R \& D$ expenses at time $t$, and positive and marginal significance relationships ( $\mathrm{p}=0.096$ for lag2 and $\mathrm{p}=0.069$ for lag 3 ) between reputations scores and $R \& D$ expenses at time $t$. In other words, the relationship significance between reputation and $R \& D$ expenses is washed away when the number of employees is included as a mediating effect. These results confirm a fully mediating effect between reputation, employees, and $R \& D$ expenses. 
Figure 21. Results for hypothesis 9 with mediating effect.

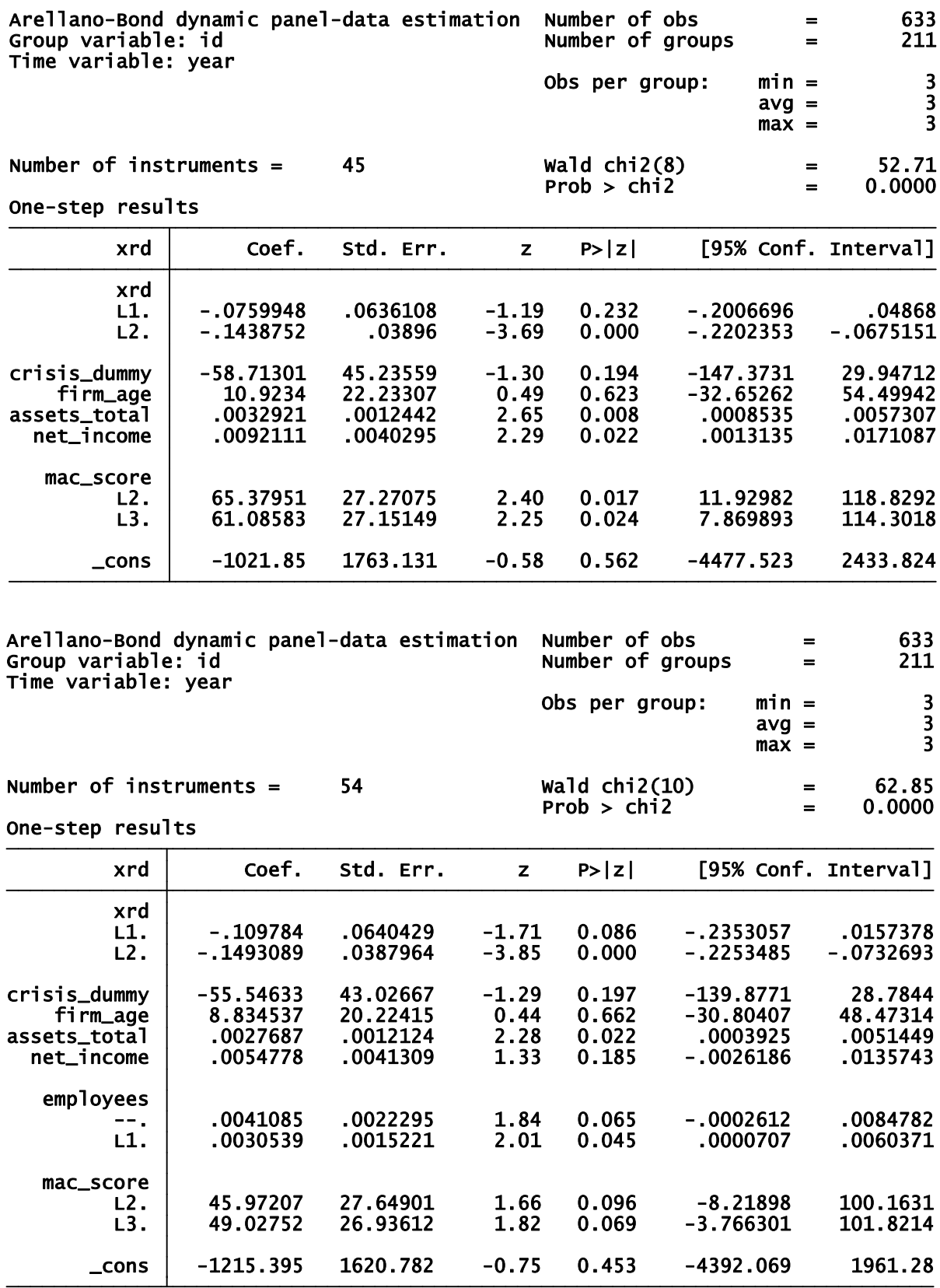

Testing hypothesis 10 .

Hypothesis 10 argues that financial capital (short and long term debts) is positively related to innovation capability ( $R \& D$ expenditure). As in the previous hypothesis testing, the predictor variables and control variables are considered to be 
endogenous in the model. If we recall hypothesis 3 , firm reputation significantly predicted financial resources (“dlc"). Results for hypothesis 10 testing are shown below.

Figure 22. Results for hypothesis 10

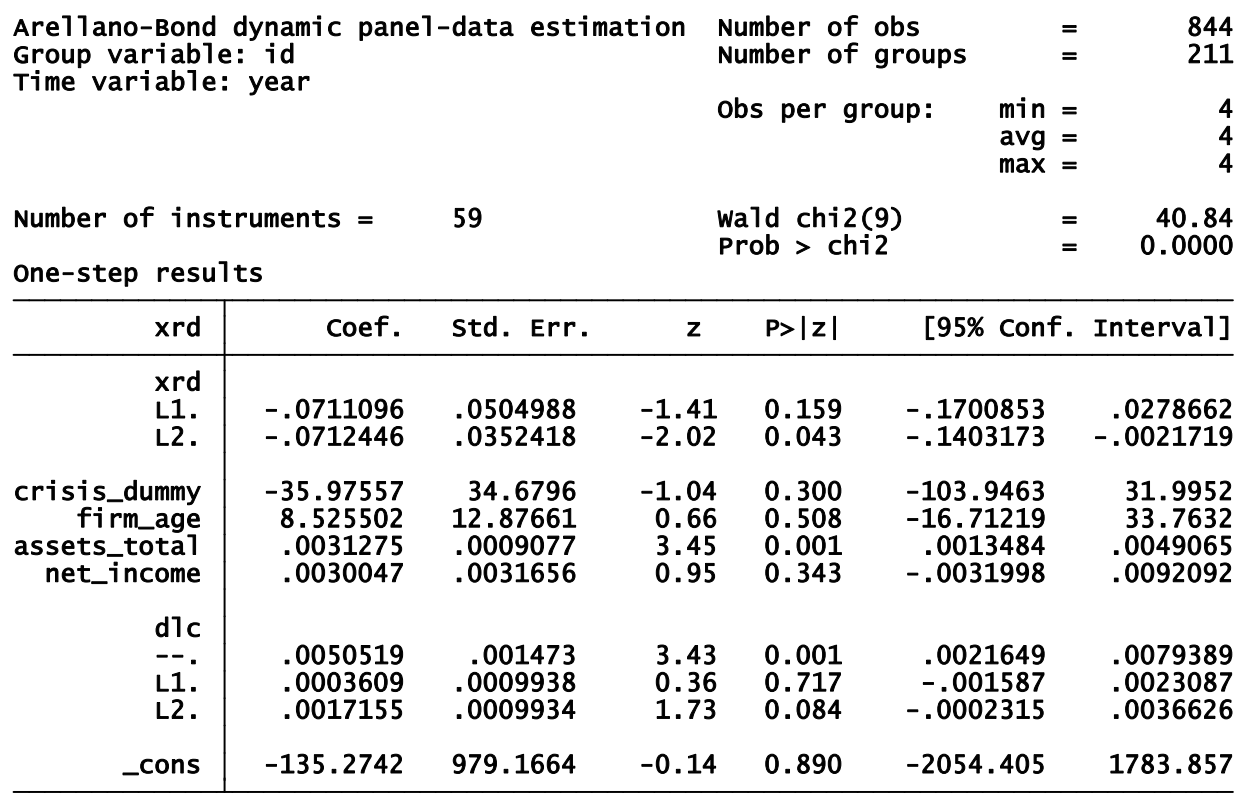

Results marginally support hypothesis 10 ; lag2 for "dlc" is marginally related to $R \& D$ expenses at time $t(p=0.084)$. As the relationship between financial resources and $R \& D$ expenses are marginally related, it is very unlikely the occurrence of the mediating effect of financial resources on the relationship between reputation and R\&D expenses. One of the requirements for the mediation effect (Baron and Kenny, 1986) is that the mediator variable and the dependent variable need to be significantly related. Testing hypothesis 11.

Hypothesis 11 suggests that the number of acquisitions (in the same country) is positively related to innovation capability ( $R \& D$ expenses). Again, the predictor and control variables are assumed to be endogenous in this model because firm reputation predicted the number of domestic acquisitions in hypothesis 4 . Results are shown below. 
Figure 23. Results for hypothesis 11

\begin{tabular}{|c|c|c|c|c|c|c|c|}
\hline \multicolumn{4}{|c|}{$\begin{array}{l}\text { Arellano-Bond dynamic pane1-data estimation } \\
\text { Group variable: id } \\
\text { Time variable: year }\end{array}$} & \multirow{2}{*}{\multicolumn{2}{|c|}{$\begin{array}{l}\text { Number of obs } \\
\text { Number of groups } \\
\text { obs per group: }\end{array}$}} & \multirow{2}{*}{$\begin{aligned} & = \\
& = \\
\min & = \\
\operatorname{avg} & = \\
\max & =\end{aligned}$} & \multirow{3}{*}{$\begin{array}{rr}= & 844 \\
= & 211 \\
= & 4 \\
= & 4 \\
= & 4 \\
= & 49.48 \\
= & 0.0000\end{array}$} \\
\hline & & & & & & & \\
\hline \multicolumn{2}{|c|}{$\begin{array}{l}\text { Number of instruments }= \\
\text { One-step results }\end{array}$} & \multicolumn{2}{|l|}{57} & \multicolumn{2}{|c|}{$\begin{array}{l}\text { vald chi2 (9) } \\
\text { rob > chi2 }\end{array}$} & & \\
\hline xrd & coef. & Std. Err. & z & $P>|z|$ & {$[95 \%$} & Conf & Interva1] \\
\hline $\begin{array}{l}\text { xrd } \\
\text { L1. } \\
\text { L2. }\end{array}$ & $\begin{array}{r}-.091742 \\
-.0959022\end{array}$ & $\begin{array}{l}.060155 \\
.0415461\end{array}$ & $\begin{array}{l}-1.53 \\
-2.31\end{array}$ & & $\begin{array}{r}-.209 \\
-.17\end{array}$ & & $\begin{array}{r}.0261596 \\
-.0144734\end{array}$ \\
\hline $\begin{array}{r}\text { crisis_dummy } \\
\text { firm_age } \\
\text { assets_total } \\
\text { net_income }\end{array}$ & $\begin{array}{r}-39.95771 \\
-21.49886 \\
.0034618 \\
.0041011\end{array}$ & $\begin{array}{l}44.23011 \\
18.55336 \\
.0011494 \\
.0038036\end{array}$ & $\begin{array}{r}-0.90 \\
-1.16 \\
3.01 \\
1.08\end{array}$ & $\begin{array}{l}0.366 \\
0.247 \\
0.003 \\
0.281\end{array}$ & $\begin{array}{l}-126 \\
-57 \\
.00 \\
-.00\end{array}$ & & $\begin{array}{l}46.73171 \\
14.86505 \\
.0057146 \\
.0115561\end{array}$ \\
\hline $\begin{array}{l}\text { Intry } \\
-- \text {. } \\
\text { L1. }\end{array}$ & $\begin{array}{r}105.0863 \\
53.93206 \\
-49.89499\end{array}$ & $\begin{array}{l}26.70369 \\
22.94741 \\
15.11015\end{array}$ & $\begin{array}{r}3.94 \\
2.35 \\
-3.30\end{array}$ & $\begin{array}{l}0.0 \\
0.0 \\
0.0\end{array}$ & $\begin{array}{r}52 . \\
8.9 \\
-79\end{array}$ & & $\begin{array}{r}157.4245 \\
98.90816 \\
-20.27964\end{array}$ \\
\hline _cons & 2039.376 & 1455.643 & 1.40 & 0.161 & -81 & 321 & 4892.383 \\
\hline
\end{tabular}

Results show that hypothesis 11 is strongly supported. Lag1 and lag2 of domestic acquisitions predict the innovation capability ("xrd") in year $\mathrm{t}(\mathrm{p}=0.019$ for lag1 and $\mathrm{p}=0.001$ for lag2). Lag2 for domestic acquisitions shows a negative coefficient. This negative coefficient is balanced out with the stronger positive effect of lag 1 of the same variable. Following the procedure explained in hypothesis 9, the mediating effect of domestic acquisitions on the relationship between firm reputation and innovation capability is tested. The exogenous predictor variable, i.e. firm reputation, needs to be lagged one more period of time in the past (i.e. t-3). As a result, there is a reduction in the number of observations to 633 or 3 groups of 211 each.

Following Baron and Kenny's (1986) procedure to test mediating effects, first, the relationship between corporate reputation and innovation capability needs to be confirmed. Second, the relationship between reputation and domestic acquisitions was confirmed in hypothesis 4 . Finally, both effects, i.e. reputation and domestic acquisitions 
need to be regressed on the innovation capability ("xrd") to test for the mediation. Results are shown in figure 24.

Figure 24. Results for hypothesis 11 with mediating effect.

\begin{tabular}{|c|c|c|c|c|c|c|c|}
\hline \multirow{2}{*}{\multicolumn{4}{|c|}{$\begin{array}{l}\text { Are } 11 \text { ano-Bond dynamic pane1-data estimation } \\
\text { Group variable: id } \\
\text { Time variable: year }\end{array}$}} & \multirow{2}{*}{\multicolumn{2}{|c|}{$\begin{array}{l}\text { Number of obs } \\
\text { Number of groups } \\
\text { obs per group: }\end{array}$}} & & \multirow{2}{*}{$\begin{array}{r}633 \\
211 \\
3 \\
3 \\
3\end{array}$} \\
\hline & & & & & & & \\
\hline \multicolumn{2}{|c|}{$\begin{array}{l}\text { Number of instruments }= \\
\text { One-step results }\end{array}$} & \multicolumn{2}{|l|}{45} & \multicolumn{2}{|c|}{$\begin{array}{l}\text { wald chi2( } 8) \\
\text { Prob > chi2 }\end{array}$} & & $\begin{array}{r}52.71 \\
0.0000\end{array}$ \\
\hline xrd & coef. & Std. Err. & z & $P>|z|$ & {$[95 \%$} & Conf & Interva1] \\
\hline $\begin{array}{l}\text { xrd } \\
\text { L1. } \\
\text { L2. }\end{array}$ & $\begin{array}{l}-.0759948 \\
-.1438752\end{array}$ & $\begin{array}{r}.0636108 \\
.03896\end{array}$ & $\begin{array}{l}-1.19 \\
-3.69\end{array}$ & $\begin{array}{l}0.232 \\
0.000\end{array}$ & $\begin{array}{l}-.200 \\
-.220\end{array}$ & $\begin{array}{l}6696 \\
2353\end{array}$ & $\begin{array}{r}.04868 \\
-.0675151\end{array}$ \\
\hline $\begin{array}{r}\text { crisis_dummy } \\
\text { firm_age } \\
\text { assets_tota1 } \\
\text { net_income }\end{array}$ & $\begin{array}{r}-58.71301 \\
10.9234 \\
.0032921 \\
.0092111\end{array}$ & $\begin{array}{l}45.23559 \\
22.23307 \\
.0012442 \\
.0040295\end{array}$ & $\begin{array}{r}-1.30 \\
0.49 \\
2.65 \\
2.29\end{array}$ & $\begin{array}{l}0.194 \\
0.623 \\
0.008 \\
0.022\end{array}$ & $\begin{array}{r}-147 \\
-32.6 \\
.000 \\
.001\end{array}$ & $\begin{array}{l}3731 \\
5262 \\
8535 \\
3135\end{array}$ & $\begin{array}{l}29.94712 \\
54.49942 \\
.0057307 \\
.0171087\end{array}$ \\
\hline $\begin{array}{l}\text { mac_score } \\
\text { L2. } \\
\text { L3. }\end{array}$ & $\begin{array}{l}65.37951 \\
61.08583\end{array}$ & $\begin{array}{l}27.27075 \\
27.15149\end{array}$ & $\begin{array}{l}2.40 \\
2.25\end{array}$ & $\begin{array}{l}0.017 \\
0.024\end{array}$ & $\begin{array}{l}11.9 \\
7.86\end{array}$ & $\begin{array}{l}2982 \\
99893\end{array}$ & $\begin{array}{l}118.8292 \\
114.3018\end{array}$ \\
\hline _cons & -1021.85 & 1763.131 & -0.58 & 0.562 & -4477 & .523 & 2433.824 \\
\hline
\end{tabular}

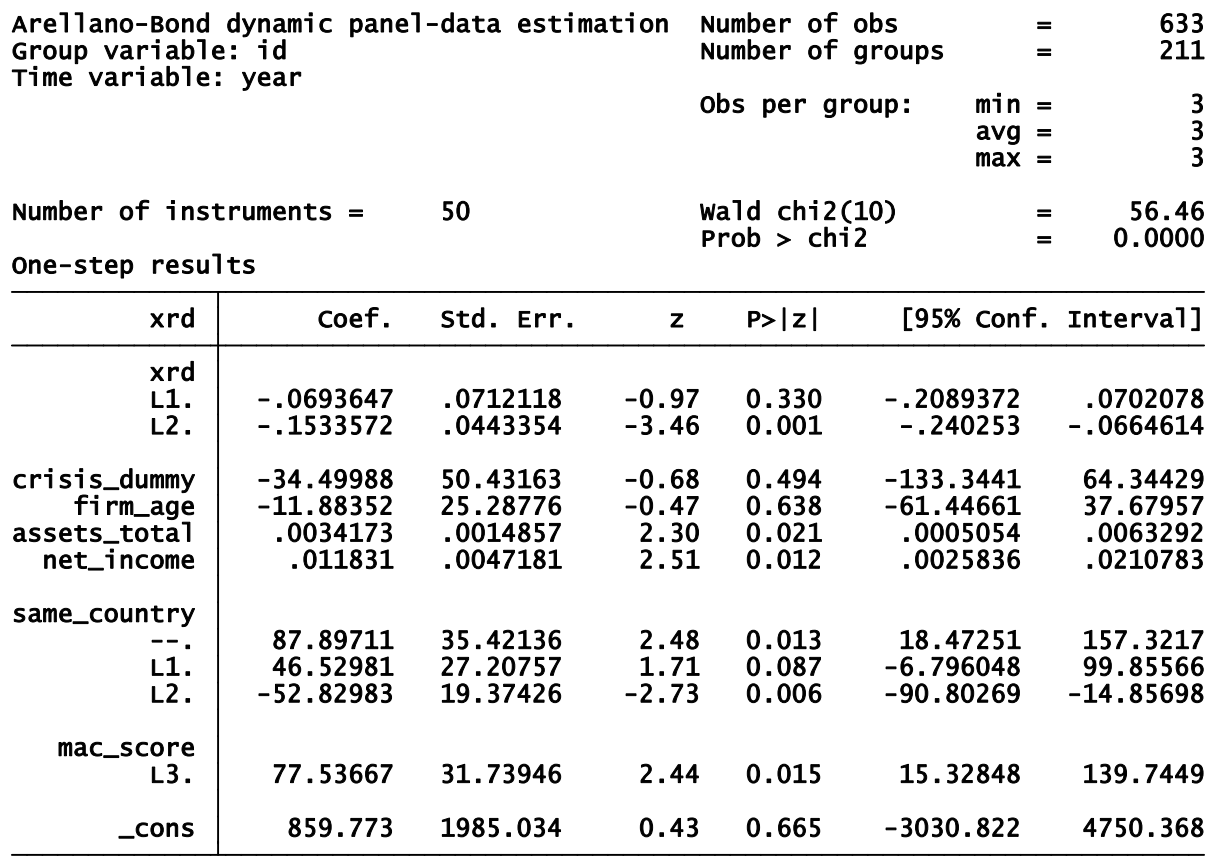

The results confirm a mediating effect of domestic acquisitions (lag2 of same_country, $\mathrm{p}=0.006$ ) on the relationship between firm reputation (lag3 of mac_score, 
$\mathrm{p}=0.015$ ) and innovation capability ( $x r d$ at time $t$ ). In simpler terms, there is a mediating effect between lag3 (t-3) firm reputation, lag2 (t-2) number of domestic acquisitions, and the innovation capability ( $R \& D$ expenses at time $t$ ); however, the coefficient is negative between lag2 domestic acquisitions and "xrd" at time $t$.

Testing hypothesis 12 .

Hypothesis 12 is straight forward. It suggests a positive relationship between innovation capability (R\&D expenses) and the performance of the firm (sales growth) (Teece, 1986). Basically, it tests whether firms can generate rents out of innovation. Predictor and control variables are assumed endogenous in the model. Results are reported in the following figure.

Figure 25. Results for hypothesis 12 .

\begin{tabular}{|c|c|c|c|c|c|c|c|}
\hline \multicolumn{4}{|c|}{$\begin{array}{l}\text { Arellano-Bond dynamic pane1-data estimation } \\
\text { Group variable: id } \\
\text { Time variable: year }\end{array}$} & \multicolumn{2}{|c|}{$\begin{array}{l}\text { Number of obs } \\
\text { Number of groups } \\
\text { obs per group: }\end{array}$} & $\begin{array}{l}\min = \\
\operatorname{avg}= \\
\max =\end{array}$ & $\begin{array}{l}844 \\
211\end{array}$ \\
\hline \multicolumn{2}{|c|}{$\begin{array}{l}\text { Number of instruments }= \\
\text { one-step results }\end{array}$} & \multirow{2}{*}{57 Std. Err. } & \multicolumn{3}{|c|}{$\begin{array}{l}\text { Wald chi2( }(9) \\
\text { Prob > chi2 }\end{array}$} & & $\begin{array}{l}130.62 \\
0.0000\end{array}$ \\
\hline sales_growth & coef. & & z & $P>|z|$ & {$[95 \%$} & Conf. & Interva1] \\
\hline $\begin{array}{r}\text { sales_growth } \\
\text { L1. } \\
\text { L2. }\end{array}$ & $\begin{array}{l}-.2991651 \\
-.2911526\end{array}$ & $\begin{array}{l}.0443589 \\
.0394456\end{array}$ & $\begin{array}{l}-6.74 \\
-7.38\end{array}$ & $\begin{array}{l}0.000 \\
0.000\end{array}$ & $\begin{array}{l}-.3 \\
-.3\end{array}$ & $\begin{array}{l}1068 \\
4645\end{array}$ & $\begin{array}{l}-.2122233 \\
-.2138406\end{array}$ \\
\hline $\begin{array}{l}\text { crisis_dummy } \\
\text { firm_age } \\
\text { assets_tota1 } \\
\text { net_income }\end{array}$ & $\begin{array}{r}-.0554362 \\
-.0055882 \\
4.47 \mathrm{e}-07 \\
-5.65 \mathrm{e}-07\end{array}$ & $\begin{array}{r}.01645 \\
.0053974 \\
4.82 \mathrm{e}-07 \\
1.86 \mathrm{e}-06\end{array}$ & $\begin{array}{r}-3.37 \\
-1.04 \\
0.93 \\
-0.30\end{array}$ & $\begin{array}{l}0.001 \\
0.301 \\
0.353\end{array}$ & $\begin{array}{l}-.0 \\
-.0 \\
-4 \\
-4\end{array}$ & 6776 & $\begin{array}{r}-.0231948 \\
.0049905 \\
1.39 \mathrm{e}-06 \\
3.08 \mathrm{e}-06\end{array}$ \\
\hline $\begin{array}{l}-- \\
\mathrm{L} 1 \\
\mathrm{~L} 2\end{array}$ & $\begin{array}{l}-.0001985 \\
-.0000163 \\
-.0001161\end{array}$ & $\begin{array}{l}.0000381 \\
.0000398 \\
.0000437\end{array}$ & $\begin{array}{l}-5.20 \\
-0.41 \\
-2.65\end{array}$ & $\begin{array}{l}0.000 \\
0.682 \\
0.008\end{array}$ & $\begin{array}{l}-.0 \\
-.0 \\
-.0\end{array}$ & $\begin{array}{l}2732 \\
0942 \\
2019\end{array}$ & $\begin{array}{r}-.0001237 \\
.0000617 \\
-.0000304\end{array}$ \\
\hline _cons & .7329896 & .4082256 & 1.80 & 0.073 & -.06 & 7118 & 1.533097 \\
\hline
\end{tabular}




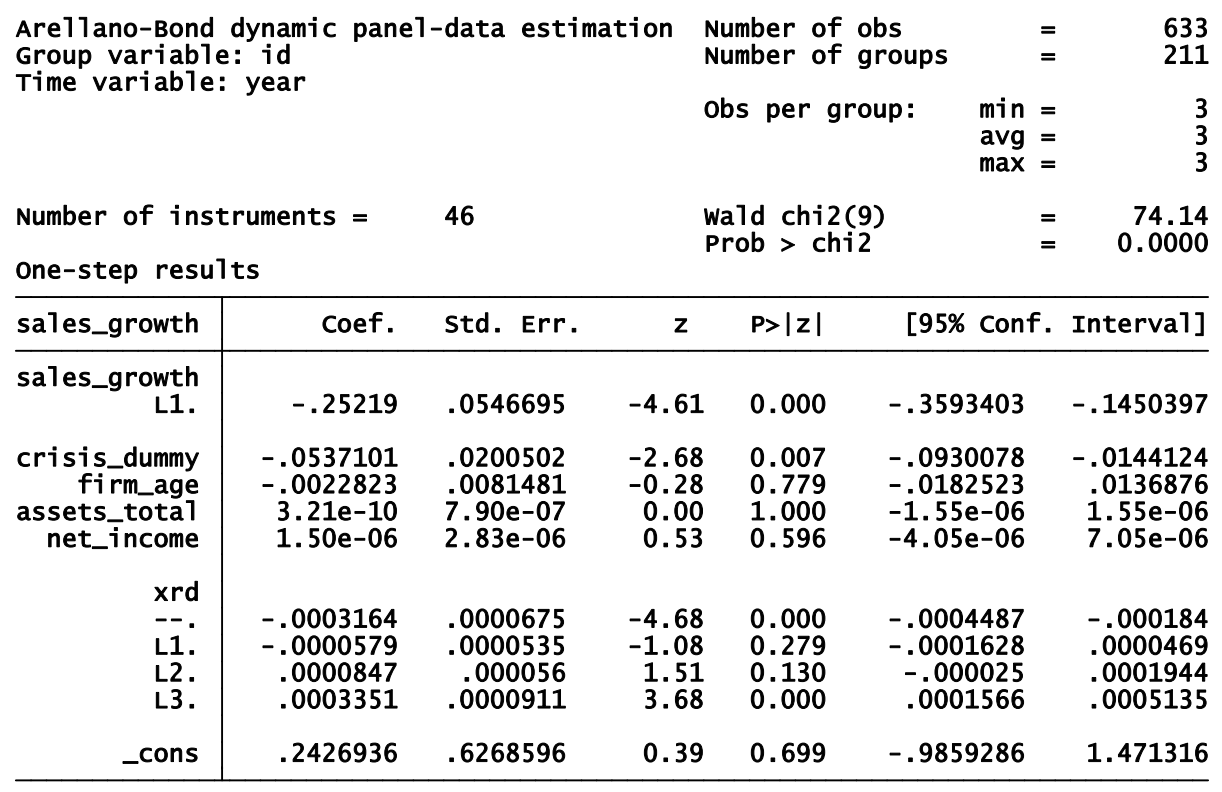

Results show that there is a significant relationship between $R \& D$ expenses (innovation capability in t-2) and firm performance (sales_growth) at time t. However, the direction of the coefficient is opposite to what it was expected. The coefficient is negative, but a weak negative coefficient. The $95 \%$ confidence interval shows that the coefficient for the lag2 of innovation capability is between -0.00020 and -0.00003 ; in other words, this coefficient is very close to zero. However, when the R\&D expenses variable is lagged 3 periods of time the coefficient becomes strongly significant in the expected direction confirming hypothesis 12 . More discussion about this phenomenon will be presented in the next chapter (Chapter VI). 


\section{CHAPTER VI}

\section{DISCUSSION}

The dissertation studied principally the mediating effect of firm innovation capability on the relationship between firm reputation and performance in 211 US firms. Results confirmed the hypotheses in most of the cases; in others, surprising results were obtained from the Arellano-Bond dynamic linear panel data estimation methodology. This methodology is appropriate for analyzing hypotheses with a longitudinal panel dataset with multiple panels (firms) and few time periods (years). The structure of the dataset allows inferring causality between variables as periods of time are considered in the analyses (lagged effects of variables).

The model for hypothesis 1 which is the main contribution of this dissertation has been fully supported. The mediating effect of innovation on the relationship between reputation and performance was confirmed by the results. The predictor variable is positively related to the mediating variable as expected; and, the mediating variable is positively and significantly related to the firm performance. Results are in line to my expectations in terms of direction and significance of the coefficients. The relationship between firm reputation and performance has been widely studied finding that a higher reputation is related to better firm performance. On a parallel research stream, innovation capability has been linked to better firm performance as well. However, the two research streams were not jointly analyzed; thus, this dissertation is the first study, at least to my knowledge, to consider both research streams together. The objective of the dissertation to confirm the mediating effect of innovation on the reputation-performance relationship 
and combining both research streams were achieved. Hence, the contribution of this dissertation is evident and significant to the respective field of research.

Robustness checks were performed using the alternative variables for each construct. For instance, in hypothesis 2, the reputation score (mac_score) was substituted by the reputation ranks: overall rank, rank following the fortune classification of industries, and the ranks following the SIC industry classification. The results showed that the overall rank and rank according to fortune classification are significant $(\mathrm{p}<0.01$ and $\mathrm{p}<0.05)$ for the lag 2 effects. In the case for the rank according to the SIC codes, the lag2 shows marginal significance $(\mathrm{p}<0.10)$. As expected, all the coefficients are negative due to the "rank" nature. In other words, the greater the rank (first, second, third, etc) the worse the reputation score. These results provide information that the model for hypothesis 2 is robust. The reputation-human capital relationship remains with different variables.

In hypothesis 3, "dlc" was changed by "dltt" (see chapter IV for variables descriptions). The relationship lag2 mac_score and dltt is positive and significant $(p<0.05)$; i.e. similar to what it was found by using "dlc". Thus, this hypothesis is also robust to tests using different variables. Also, the correlation matrix for the coefficients shows no major issues with multicollinearity. VIFs are low for the independent and control variables.

Hypothesis 4 is one of the most robust to different checks. It has been previously argued that US firms tend, in average, to engage in domestic and related acquisitions. By changing the "same_country" for "sameSIC2", the results are similar in terms of direction of the coefficient as well as the significance level. Also, the reputation measures 
were changed to ranks and the results remained in the expected direction and with strong significance. For exemplification purposes, the relationship between "lag2 of rank_sic" and "sameSIC2" is $-0.0074(\mathrm{p}=0.006)$; all the other possibilities are similar to this in terms of the direction and significance of the coefficients. "lag2 mac_score" and "num_acquistions" remains positive and marginally supported $(0.2364 ; \mathrm{p}=0.083)$ with the inclusion of two more variables: percentage of domestic firms and percentage of firms with the same SIC codes at 2-digit level. I can conclude from these robustness checks that the effects of US firms acquiring foreign firms is negligible; studies analyzing acquisitions transactions of US firms should consider domestic targets as opposed to the total number of acquisitions (foreign + domestic).

In the robustness checks for hypothesis 5, 6, and 7 (moderating effects of DOI_MJAV), the degree of internationalization measure was changed to DOI_FSTS, i.e. a ratio of foreign sales to total sales. Results show that in the case of human capital, the interaction effect is marginally supported $(\mathrm{p}<0.10)$; in the case of the financial capital, the interaction effect is not significant; and, for the knowledge and new technologies access (acquisitions), the interaction effect is significant ( $<<0.05$ ). Results vary by applying the DOI change. The proposed degree of internationalization (DOI_MJAV) provides better results than the DOI_FSTS. It has shown that the proposed measure is more complete as it addresses the breadth and depth of international operations as it considers not only the foreign sales to total sales (depth), but also the number of countries in which the firm operates and the foreign subsidiaries to total affiliates (breadth). The pairwise correlation between both measures is 0.5652 and is strongly significant $(\mathrm{p}<0.001$ for 1477 observations). The proposed DOI is, actually, measuring the same phenomenon as the 
DOI_FSTS; the only difference is that the proposed DOI has more detail and variability in its calculations. For example, the DOI_FSTS ranges from 0 to 1 as it is a ratio; on the other hand, DOI_MJAV range from 0 to any positive real number; the limit will be the number of countries in the world; in other words, the upper limit would be around 200. The maximum possible number would be if a firm's revenues are $100 \%$ in foreign markets, $100 \%$ of its subsidiaries are foreign, and the firm is located in all possible countries in the world. Therefore, the proposed DOI measure possesses more variability which results have shown a positive effect on the explanation of certain phenomena. It is recommended that more empirical research should be performed to confirm the better effects of this measure, contrasting with the FSTS measure. The other contribution of the dissertation is also important and significant for the research advancements.

In hypotheses 9,10 , and 11 the innovation capability (R\&D expenses) has been changed to the number of patents, $R \& D$ expenses per patent, and $R \& D$ expenses as a percentage of revenues. Similar results are obtained when the outcome variable is changed to the number of patents and R\&D expenses per patent; however, the R\&D expenses as a percentage of revenues (or sales) provides no significant results whatsoever. I can explain this circumstance because the R\&D expenses to sales depend on the firm revenues as well as the sales growth for the firm. Literature has suggested using $\mathrm{R} \& \mathrm{D}$ expenses or patents as proxies for innovation capability; robustness checks confirm the conclusions made in the literature. $R \& D$ expenses per patent is a weaker proxy for the firm innovation capability; however, isolating some industries would enhance the properties of the "rd_patent" measure because there are industries in which patents are more required than in others. 
Finally, hypothesis 12 provides surprising results. The expected sign for the relationship was positive; however, results show significant coefficient, but negative. I changed the $R \& D$ expenses to patents and the results show negative significant coefficient as well. However, patents and return on assets (ROA) provides positive results. R\&D expenses and ROA provide positive results, but marginal. Something interesting and perhaps the explanation of these unexpected results is evident when I reduced the sample to only manufacturing companies, i.e. SIC codes from 2000 to 3999. The coefficient becomes positive and significant as expected and described in the literature. Firms in the manufacturing industry need more patents and invest more in $R \& D$ in order to remain profitable in the environment. As a result, these firms enjoy sales growth and/or higher returns on assets. The drawback for dividing the sample into manufacturing firms only is the reduction in the number of observations and firms. They went down to 78 firms with 312 observations, a trade-off that has to be analyzed closely in future research. Also, as shown in figure 25, I lagged the R\&D expenses variable ("xrd") by 3 years and results showed a positive and significant relationship to sales growth as expected and found in the literature. In other words, investments in R\&D may be reflected after 3 years in terms of sales growth. This is not uncommon for manufacturing as well as service firms as they start enjoying the benefits of R\&D investments after the second, or in this case after the third year. 


\section{CHAPTER VII}

\section{CONCLUSIONS, LIMITATIONS, FUTURE RESEARCH, AND RELEVANCE FOR PRACTITIONERS}

The dissertation explores the mediating effect of innovation capability on the reputation-performance relationship. It makes an effort to integrate two research streams which remained independent in the literature. One stream of research studies the reputation-performance relationship; scholars argue that tangible as well as intangible assets, e.g. firm reputation, provide competitive advantage to the firm which can be translated in higher firm performance. Authors base their rationale in grounded theories such as the resource-based view of the firm (Barney, 1991; Rumelt, 1984;Wernerfelt, 1984), and the institutional theory (DiMaggio and Powell, 1983; Hannan and Freeman, 1984; Meyer and Rowan, 1977; Pfeffer and Salancik, 1978; Scott, 1994), among the most relevant. The second research stream studies the innovation-performance relationship. Scholars in the technology management and management in general stipulate that innovation is of extreme importance for the firm survival (Schumpeter, 1942; Teece, 1986) and performance; firms can appropriate rents from innovation. Scholars in these two research streams have been dedicating their time and efforts to explain by conceptual and empirical studies the phenomena found in the business environment. However, the paths remained in parallel. It is with this dissertation that I am attempting to find a common ground for both research streams in which they can explain a specific phenomenon. The proposed model confirmed the mediating effect of innovation on the relationship between firm reputation and performance; these findings are validated for 211 US firms in the time span of 7 years. The model is robust to different tests with 
similar variables (robustness checks) providing very similar results. Causal inferences were possible because the sample structure, longitudinal panel data, allows it.

In a different but related field, i.e. international business, this dissertation attempts to make a contribution as well. For many decades, an active debate on the relationship between multinationality and performance (M-P) in MNCs has called the attention of many scholars in the international business field. Researchers have found multiple forms for the M-P relationship, e.g. no relationship whatsoever, positive linear, negative linear, U-shape, inverted U-shape, sigmoidal, etc. These studies' mix findings are attributable to a lack of convergence on the measure of the firm degree of internationalization (DOI). In the 90s, many scholars have proposed different techniques to measure DOI; however, consensus was not achieved. As a result, scholars are still contributing to the debate in finding better alternatives to measure DOI responding to the call from experts to contribute in the topic. In this dissertation, I propose a new measure for the firm DOI which takes into account the breadth and depth of the firm's international operations. With this measure, I am not deviating too much from the most accepted type of measure, i.e. foreign sales as ratio of the total sales; in fact, the proposed DOI is build upon it providing more detail in the calculations and correcting for shortcomings found in the previous DOI measure. Results show that both measures are correlated; however, the proposed measure provides results which the other measure does not. This effect is attributable to the increased variation among the observations in the proposed DOI. Again, I attempt to contribute in the field of international business and more empirical research is needed in order to reinforce the acceptance of this new measure in the 
literature. Research comparing and contrasting both measures would be of great importance.

This dissertation is by no means without some limitations. It is a longitudinal panel data; however, the time window is 7 years only. Future research should increase the time span for more years to achieve statistical power in the estimations. Although the Arellano-Bond dynamic linear panel data estimators are designed for dataset with several panels with fewer time observations, more observations are always better. The dissertation relied only on data from US firms; future research might consider including firms from other countries, and perhaps firms from emerging economies in order to achieve greater generalizations. This dissertation used data from 211 firms in 8 industries; future research may partition the sample in similar industries in order to achieve more detail per industry providing insightful conclusions for a specific industry.

Finally, this dissertation relevance for practitioners is to provide some insightful information about the alternatives managers have to reap the benefits of high reputational position compared to their counterparts. Firm reputation can attract critical resources for new product developments (innovation) such as talented human capital and financial capital with better conditions; hence, the ultimate importance for managers to keep and/or improve the firm reputation. Firms need to innovate in order to secure their survival and growth in the environment. Firms are in the constant search for new knowledge and technologies for innovation; acquisitions are a good alternative when acquiring companies want more control and full access to the knowledge, technologies, and capabilities of the target organization. Strategic alliances or joint ventures may provide limited access to vital information, or technology to the partners. Results show that in 
average US firms tend to acquire companies domestically and in related industries. Managers should be aware of the complexity of foreign and unrelated acquisitions. However, the risks are reduced as the firms "learn" the process of acquiring foreign and unrelated firms. Results in this dissertation suggest that firm reputation and innovation capabilities are strongly linked to firm performance; hence, managers need to have them as priorities in their strategic decisions. 


\section{REFERENCES}

Adner, R., and Levinthal, D. (2001). Demand heterogeneity and technology evolution: Implications for product and process innovation. Management Science, 47(5), 611-628.

Afuah, A. (2003). Innovation management - Strategies, implementation, and profits. New York/Oxford: Oxford University Press.

Ahuja, G., and Katila, R. (2001). Technological acquisitions and the innovation performance of acquiring firms: A longitudinal study. Strategic Management Journal, 22(3), 197-220.

Aiken, L.S. and West, S.G. (1991). Multiple regression: Testing and interpreting interactions. Thousand Oaks, CA: Sage Publications.

Allison, P. (1984). Event history analysis - Regression for longitudinal event data, Beverly Hills, CA: Sage Publications.

Alvarado-Vargas, M. J. (2008). The technological innovation adoption race: Things you must know to finish it in first places. The Business Review, Cambridge, 11(2), 76-81.

Amit, R., and Schoemaker, P. J. (1993). Strategic assets and organizational rent. Strategic Management Journal, 14(1), 33-46.

Antonelli, C., and Calderini, M. (1999). The dynamics of localized technological change. In A. Gambardelli and F. Malerba (Eds.), The Organization of Economic Innovation in Europe, 158-176. Cambridge: Cambridge University Press.

Arellano, M., and Bond, S. (1991). Some tests of specification for panel data: Monte Carlo evidence and an application to employment equations. The Review of Economic Studies, 58(2), 277-297.

Ariss, S. S., and Deilami, V. S. (2012). An integrated framework for the study of organizational innovation. International Journal of Innovation and Technology Management, 9(1), 1-26.

Assink, M. (2006). Inhibitors of disruptive innovation capability: A conceptual model. European Journal of Innovation Management, 9(2), 215-233.

Avermaete, T., Viaene, J., Morgan, E. J., and Crawford, N. (2003). Determinants of innovation in small food firms. European Journal of Innovation Management, 6(1), 8-17.

Barczak, G., Griffin, A., and Kahn, K. B. (2009). Perspective: Trends and drivers of success in NPD practices: Results of the 2003 PDMA best practices study. Journal of Product Innovation Management, 26(1), 3-23. 
Barney, J. (1986). Strategic factor markets: Expectations, luck, and business strategy. Management Science, 32(10), 1231-1241.

Barney, J. (1991). Firm resources and sustained competitive advantage. Journal of Management, 17(1), 99-120.

Baron, R. M., and Kenny, D. A. (1986). The moderator-mediator variable distinction in social psychological research: Conceptual, strategic, and statistical considerations. Journal of Personality and Social Psychology, 51, 1173-1182.

Bartlett, C. A., and Ghoshal, S. (1987). Managing across borders: New organizational responses. Sloan Management Review, 29(1), 43.

Basdeo, D. K., Smith, K. G., Grimm, C. M., Rindova, V. P., and Derfus, P. J. (2006). The impact of market actions on firm reputation. Strategic Management Journal, 27(12), 1205-1219.

Becker, S. W., and Whisler, T. L. (1967). The innovative organization: A selective view of current theory and research. The Journal of Business, 40(4), 462-469.

Benjamin, B. A., and Podolny, J. M. (1999). Status, quality, and social order in the california wine industry. Administrative Science Quarterly, 44(3), 563-589.

Berens, G., and van Riel, C. (2004). Corporate associations in the academic literature: Three main streams of thought in the reputation measurement literature. Corporate Reputation Review, 7(2), 161-178.

Bergh, D. D., Ketchen, D. J., Boyd, B. K., and Bergh, J. (2010). New frontiers of the reputation-Performance relationship: Insights from multiple theories. Journal of Management, 36(3), 620-632.

Betz, F. (2003). Managing technological innovation, Hoboken, NJ: John Wiley \& Sons.

Bhattacharya, M., and Bloch, H. (2004). Determinants of innovation. Small Business Economics, 22(2), 155-162.

Bornheim, S. P., and Herbeck, T. H. (1998). A research note on the theory of SME - bank relationships. Small Business Economics, 10(4), 327-331.

Boyd, B. K., Bergh, D. D., and Ketchen, D. J. (2010). Reconsidering the ReputationPerformance relationship: A resource-based view. Journal of Management, 36(3), 588609.

Breschi, S. (1999). Spatial patterns of innovation: Evidence from patent data. In A. Gambardella, and F. Malerba (Eds.). The Organization of Economic Innovation in Europe. Cambridge: Cambridge University Press, 71-102. 
Bresnahan, T. F., Stern, S., and Trajtenberg, M. (1997). Market segmentation and the sources of rents from innovation: Personal computers in the late 1980s. The Rand Journal of Economics, 28, S17-S44.

Bromley, D. B. (1993). Reputation, image, and impression management. Chichester: Wiley.

Brown, T. J. (1998). Corporate associations in marketing: Antecedents and consequences. Corporate Reputation Review, 1(3), 215-233.

Buckley, P. and Casson, M. (1976). The future of the multinational enterprise. London: Macmillan and Co.

Bühner, R. (1987). Assessing international diversification of west german corporations. Strategic Management Journal, 8(1), 25-37.

Burt, S. L., and Sparks, L. (2002). Corporate branding, retailing, and retail internationalization. Corporate Reputation Review, 5(2/3), 194-212.

Cable, D. M., and Graham, M. E. (2000). The determinants of job seekers' reputation perceptions. Journal of Organizational Behavior, 21(8), 929-947.

Caves, R.E. (1971). International corporations: The industrial economics of foreign investment. Economica, 1-27.

Chandy, R. K., and Tellis, G. J. (2000). The incumbent's curse? incumbency, size, and radical product innovation. Journal of Marketing, 64(3), 1-17.

Chen, S. S., and Zeng, M. (2004). Japanese investors' choice of acquisitions vs. startups in the US: The role of reputation barriers and advertising outlays. International Journal of Research in Marketing, 21(2), 123-136.

Chesbrough, H. W., and Teece, D. J. (1996). When is virtual virtuous? Organizing for innovation. Harvard Business Review, 74, 65.

Christensen, C. (1997). The innovator's dilemma: When new technologies cause great firms to fail. Cambridge, MA: Harvard Business School Press.

Cohen, W. M., and Levinthal, D. A. (1990). Absorptive capacity: A new perspective on learning and innovation. Administrative Science Quarterly, 35(1), 128-152.

Contractor, F. J., Kundu, S. K., and Hsu, C. (2003). A three-stage theory of international expansion: The link between multinationality and performance in the service sector. Journal of International Business Studies, 34(1), 5-18.

Cooper, J. R. (1998). A multidimensional approach to the adoption of innovation. Management Decision, 36(8), 493-502. 
Cuervo-Cazurra, A., Maloney, M. M., and Manrakhan, S. (2007). Causes of the difficulties in internationalization. Journal of International Business Studies, 38(5), 709725.

Dacin, M. T. (1997). Isomorphism in context: The power and prescription of institutional norms. Academy of Management Journal, 40(1), 46-81.

Damanpour, F., Szabat, K. A., and Evan, W. M. (1989). The relationship between types of innovation and organizational performance. The Journal of Management Studies, 26(6), 587.

Daniels, J. D., and Bracker, J. (1989). Profit performance: Do foreign operations make a difference? Management International Review, 29(1), 46-56.

Deephouse, D. L. (1996). Does isomorphism legitimate? Academy of Management Journal, 39(4), 1024-1039.

Deephouse, D. L. (2000). Media reputation as a strategic resource: An integration of mass communication and resource-based theories. Journal of Management, 26(6), 10911112 .

Deephouse, D. L., and Carter, S. M. (2005). An examination of differences between organizational legitimacy and organizational reputation. Journal of Management Studies, 42(2), 329-360.

Deephouse, D. L., Li, L., and Newburry, W. (2009). Institutional and national culture effects on corporate reputation. Academy of Management Proceedings, 2009(1) 1-6.

Diamond, D. W. (1991). Monitoring and reputation: The choice between bank loans and directly placed debt. The Journal of Political Economy, 99(4), 689.

DiMaggio, P. J., and Powell, W. W. (1983). The iron cage revisited: Institutional isomorphism and collective rationality in organizational fields. American Sociological Review, 48(2), 147-160.

Dodgson, M., and Gann, D. (2010). Innovation: A very short introduction. Oxford: Oxford University Press.

Dollinger, M. J., Golden, P. A., and Saxton, T. (1997). The effect of reputation on the decision to joint venture. Strategic Management Journal, 18(2), 127-140.

Dunning, J. H. (1980). Toward an eclectic theory of international production: Some empirical tests. Journal of International Business Studies, 11(1), 9-31.

Dunning, J. H. (1988). Multinationals, technology and competitiveness. London: Unwin Hyman. 
Dunning, J. H. (1995). Reappraising the eclectic paradigm in an age of alliance capitalism. Journal of International Business Studies, 26(3), 461-491.

Eppink, D. J., and Van Rhijn, B. M. (1988). The internationalization of dutch insurance companies. Long Range Planning, 21(5), 54-60.

Fabrizio, K. R., and Thomas, L. G. (2012). The impact of local demand on innovation in a global industry. Strategic Management Journal, 33(1), 42-64.

Fombrun, C. J. (1996). Reputation: Realizing value from the corporate image. Cambridge, MA: Harvard Business Press.

Fombrun, C., and Shanley, M. (1990). What's in a name? Reputation building and corporate strategy. Academy of Management Journal, 33(2), 233-258.

Fombrun, C. J., and van Riel, C. B. (2004). Fame and Fortune: How Successful Companies Build Winning Reputations. Upper Saddle River, NJ: Financial Times Press.

Garbett, T. (1988). How to build a corporation's identitity and project its image.

Lexington: Lexington Books.

Garcia, R., and Calantone, R. (2002). A critical look at technological innovation typology and innovativeness terminology: A literature review. Journal of Product Innovation Management, 19(2), 110-132.

Gardberg, N. A. (2006). Reputatie, reputation, reputation, reputazione, ruf: A crosscultural qualitative analysis of construct and instrument equivalence. Corporate Reputation Review, 9(1), 39-61.

Geringer, J. M., and Hebert, L. (1989). Control and performance of international joint ventures. Journal of International Business Studies, 20(2), 235-254.

Gomes, L., and Ramaswamy, K. (1999). An empirical examination of the form of the relationship between multinationality and performance. Journal of International Business Studies, 30(1), 173-187.

Grant, R. M. (1987). Multinationality and performance among british manufacturing companies. Journal of International Business Studies, 18(3), 79-89.

Grant, R. M. (1991). The resource-based theory of competitive advantage: Implications for strategy formulation. California Management Review, Spring, 114-135.

Grant, R. M., Jammine, A. P., and Thomas, H. (1988). Diversity, diversification, and profitability among British manufacturing companies, 1972-84. Academy of Management Journal, 31(4), 771-801. 
Haar, J. (1989). A comparative analysis of the profitability performance of the largest US, European and Japanese multinational enterprises. Management International Review, 29(3), 5-18.

Hall, R. (1992). The strategic analysis of intangible resources. Strategic Management Journal, 13(2), 135-144.

Hannan, M. T., and Freeman, J. (1984). Structural inertia and organizational change. American Sociological Review, 49(2), 149-164.

Henard, D. H., and Dacin, P. A. (2010). Reputation for product innovation: Its impact on consumers. Journal of Product Innovation Management, 27(3), 321-335.

Henderson, R. M., and Clark, K. B. (1990). Architectural innovation: The reconfiguration of existing product technologies and the failure of established firms. Administrative Science Quarterly, 35(1), 9.

Hennart, J. (2007). The theoretical rationale for a multinationality-performance relationship. Management International Review, 47(3), 423-452.

Hill, C. W. L., and Rothaermel, F. T. (2003). The performance of incumbent firms in the face of radical technological innovation. Academy of Management.the Academy of Management Review, 28(2), 257-274.

Hillman, A. J., Withers, M. C., and Collins, B. J. (2009). Resource dependence theory: A review. Journal of Management, 35(6), 1404-1427.

Hitt, M. A., Hoskisson, R. E., and Kim, H. (1997). International diversification: Effects on innovation and firm performance in product-diversified firms. Academy of Management Journal, 40(4), 767-798.

Hymer, S. (1976). The international operations of national firms: A study of direct foreign investment. Cambridge, MA: MIT press.

Jaffe, A. B. (1986). Technological Opportunity and Spillovers of R\&D: Evidence from Firms' Patents, Profits and Market Value. The American Economic Review, 76(5), 984.

Jaffe, A. B., Trajtenberg, M., and Henderson, R. (1993). Geographic localization of knowledge spillovers as evidenced by patent citations. The Quarterly Journal of Economics, 108(3), 577-598.

Jensen, M., and Roy, A. (2008). Staging exchange partner choices: When do status and reputation matter? Academy of Management Journal, 51(3), 495-516.

Johanson, J., and Vahlne, J. (1977). The internationalization process of the firm-a model of knowledge development and increasing foreign market commitments. Journal of International Business Studies, 8(1), 23-32. 
Kafouros, M. I., Buckley, P. J., and Clegg, J. (2012). The effects of global knowledge reservoirs on the productivity of multinational enterprises: The role of international depth and breadth. Research Policy, 41(5), 848.

Kafouros, M. I., Buckley, P. J., Sharp, J. A., and Wang, C. (2008). The role of internationalization in explaining innovation performance. Technovation, 28(1/2), 63.

Kaul, A. (2012). Technology and corporate scope: Firm and rival innovation as antecedents of corporate transactions. Strategic Management Journal, 33(4), 347-367.

Kerr, C. (1963). The Uses of the University. Cambridge, MA: Harvard University Press.

Kirca, A. H., Hult, G. T. M., Roth, K., Cavusgil, S. T., Perryy, M. Z., Akdeniz, M. B., Deligonul, S. Z., Mena, J. A., Pollitte, W. A., Hoppner, J. J., Miller, J. C., and White, R.C. (2011). Firm-specific assets, multinationality, and financial performance: A metaanalytic review and theoretical integration. Academy of Management Journal, 54(1), 4772 .

Klein, B., and Leffler, K. B. (1981). The role of market forces in assuring contractual performance. The Journal of Political Economy, 89(4), 615-641.

Knight, K. E. (1967). A descriptive model of the intra-firm innovation process. The Journal of Business, 40(4), 478-496.

Koberg, C. S., Detienne, D. R., and Heppard, K. A. (2003). An empirical test of environmental, organizational, and process factors affecting incremental and radical innovation. Journal of High Technology Management Research, 14(1), 21-45.

Kramer, J., Marinelli, E., Iammarino, S., and Revilla-Diez, J. (2011). Intangible assets as drivers of innovation: Empirical evidence on multinational enterprises in german and UK regional systems of innovation. Technovation, 31(9), 447-458.

Leifer, R., McDermott, C.M., O'Connor, G.C., Peters, L.S., Rice, M., and Veryzer, R.W. (1994). Radical innovation: How mature companies can outsmart upstarts. Boston, MA: Harvard Business School Press.

Lessard, D. R. (1976). World, country, and industry relationships in equity returns. Financial Analysts Journal, 32(1), 32.

Love, E. G., and Kraatz, M. (2009). Character, conformity, or the bottom line? how and why downsizing affected corporate reputation. Academy of Management Journal, 52(2), 314-335.

Love, J. H., and Roper, S. (1999). The determinants of innovation: R and D, technology transfer and networking effects. Review of Industrial Organization, 15(1), 43-64. 
Lu, J. W., and Beamish, P. W. (2001). The internationalization and performance of SMEs. Strategic Management Journal, 22(6-7), 565-586.

MacKinnon, D. P., Lockwood, C. M., Hoffman, J. M., West, S. G., and Sheets, V. (2002). A comparison of methods to test mediation and other intervening variable effects. Psychological Methods, 7(1), 83-104.

Makino, S., Lau, C., and Yeh, R. (2002). Asset-exploitation versus asset-seeking: Implications for location choice of foreign direct investment from newly industrialized economies. Journal of International Business Studies, 33(3), 403-421.

Malerba, F., and Orsenigo, L. (1995). Schumpeterian patterns of innovation. Cambridge Journal of Economics, 19(1), 47-65.

Meyer, J. W., and Rowan, B. (1977). Institutionalized organizations: Formal structure as myth and ceremony. American Journal of Sociology, 83(2), 340-363.

Michael Geringer, J., Beamish, P. W., and DaCosta, R. C. (1989). Diversification strategy and internationalization: Implications for MNE performance. Strategic Management Journal, 10(2), 109-119.

Nachum, L. (2000). Economic geography and the location of TNCs: Financial and professional service FDI to the USA. Journal of International Business Studies, 31(3), $367-385$.

Neely, A. (1999). The performance measurement revolution: Why now and what next? International Journal of Operations and Production Management, 19(2), 205-228.

Nelson, R. R., and Winter, S. G. (1982). An evolutionary theory of economic change. Cambridge, MA: Harvard University Business press.

Newburry, W. (2010). Reputation and supportive behavior: Moderating impacts of foreignness, industry and local exposure. Corporate Reputation Review, 12(4), 388-405.

Nohria, N., and Gulati, R. (1996). Is slack good or bad for innovation? Academy of Management Journal, 39(5), 1245-1264.

Penrose, E. (1959). The growth of the firm. White Plains, New York: ME Sharpe.

Peteraf, M. A. (1993). The cornerstones of competitive advantage: A resource-based view. Strategic Management Journal, 14(3), 179-191.

Petruzzelli, A. M. (2011). The impact of technological relatedness, prior ties, and geographical distance on university-industry collaborations: A joint-patent analysis. Technovation, 31(7), 309. 
Pfarrer, M. D., Pollock, T. G., and Rindova, V. P. (2010). A tale of two assets: The effects of firm reputation and celebrity on earnings surprises and investors' reactions. Academy of Management Journal, 53(5), 1131-1152.

Pfeffer, J., and Salancik, G. R. (1978). The external control of organizations: A resource dependence approach. New York: Harper and Row Publishers.

Porter, M. (1990). The competitive advantage of nations. Harvard Business Review, 68(2), 73-93.

Rajan, R. G. (1992). Insiders and outsiders: The choice between informed and arm'slength debt. The Journal of Finance, 47(4), 1367.

Ramaswamy, K., Kroeck, K. G., and Renforth, W. (1996). Measuring the degree of internationalization of a firm: A comment. Journal of International Business Studies, 27(1), 167-177.

Riahi-Belkaoui, A. (1998). The effects of the degree of internationalization on firm performance. International Business Review, 7(3), 315-321.

Rindova, V. P., Williamson, I. O., and Petkova, A. P. (2010). Reputation as an intangible asset: Reflections on theory and methods in two empirical studies of business school reputations. Journal of Management, 36(3), 610-619.

Rindova, V. P., Williamson, I. O., Petkova, A. P., and Sever, J. M. (2005). Being good or being known: An empirical examination of the dimensions, antecedents, and consequences of organizational reputation. Academy of Management Journal, 48(6), 1033-1049.

Rindova, V. P., Yeow, A., Martins, L. L., and Faraj, S. (2012). Partnering portfolios, value-creation logics, and growth trajectories: A comparison of Yahoo and Google (1995 to 2007). Strategic Entrepreneurship Journal, 6(2), 133-151.

Roberts, E. B. (2007). Managing invention and innovation. Research-Technology Management, 50(1), 35-54.

Roberts, P. W., and Dowling, G. R. (2002). Corporate reputation and sustained superior financial performance. Strategic Management Journal, 23(12), 1077-1093.

Roberts, E. B. (2007). Managing invention and innovation. Research Technology Management, 50(1), 35-54.

Roberts, E. B., and Berry, C. A. (1985). Entering new businesses: Selecting strategies for success. Sloan Management Review (Pre-1986), 26(3), 3.

Romijn, H., and Albaladejo, M. (2002). Determinants of innovation capability in small electronics and software firms in southeast England. Research Policy, 31(7), 1053-1067. 
Rosenberg, N., and Nelson, R. R. (1994). American universities and technical advance in industry. Research Policy, 23(3), 323.

Rugman, A. M. (1983). The comparative performance of US and european multinational enterprises, 1970-79. Management International Review, 23(2), 4-14.

Ruigrok, W., and Wagner, H. (2003). Internationalization and performance: An organizational learning perspective. Management International Review, 43(1), 63-83.

Rumelt, R.P.(1984). Toward a strategic theory of the firm. In V. R. Lamb (Ed.), Competitive Strategic Management. Englewood Cliffs, NJ: Prentice-Hall.

Sabate, J. M. de la F., and Puente, E. de Q. (2003). Empirical analysis of the relationship between corporate reputation and financial performance: A survey of the literature.

Corporate Reputation Review, 6(2), 161-177.

Saxton, T., and Dollinger, M. (2004). Target reputation and appropriability: Picking and deploying resources in acquisitions. Journal of Management, 30(1), 123-147.

Schilling, M.A. (2010). Strategic management of technological innovation. New York: McGraw-Hill/Irwin.

Schumpeter, J. A. (1942). Capitalism, Socialism and Democracy. New York: Harper.

Schumpeter, J. A. (2008). Capitalism, Socialism, and Democracy. New York: Harper Perennial Modern Classics.

Scott, W. R. (1994). Institutions and organizations: Toward a theoretical synthesis. In W. R. Scott, and J. W. Meyer (Eds.). Institutional Environments and Organizations:

Structural Complexity and Individualism. Thousand Oaks, CA: Sage Publications, 55-80.

Scott, W. R. (2004). Reflections on a half-century of organizational sociology. Annual Review of Sociology, 30, 1-21.

Scott, W. R. (2007). Institutions and organizations: Ideas and interests. Thousand Oaks, CA: Sage Publications, Inc.

Servaes, H., and Zenner, M. (1996). The role of investment banks in acquisitions. The Review of Financial Studies, 9(3), 787.

Smith, K. (2005). Measuring innovation. In Fagerberg, J., Mowery, D.C., and Nelson, R.R. The Oxford Handbook of Innovation. Oxford/New York: Oxford University Press.

Spence, M. (1973). Job market signaling. The Quarterly Journal of Economics, 87(3), 355-374. 
Standifird, S. S. (2001). Reputation and e-commerce: EBay auctions and the asymmetrical impact of positive and negative ratings. Journal of Management, 27(3), 279-295.

Stopford, J. M., and Wells, L. T. (1972). Managing the multinational enterprise:

Organization of the firm and ownership of the subsidiaries. New York: Basic Books.

Suchman, M. C. (1995). Managing legitimacy: Strategic and institutional approaches. Academy of Management Review, 20(3), 571-610.

Sullivan, D. (1994). Measuring the degree of internationalization of a firm. Journal of International Business Studies, 25(2), 325-342.

Sullivan, D. (1996). Measuring the degree of internationalization of a firm: A reply. Journal of International Business Studies, 27(1), 179-192.

Sullivan, D., and Bauerschmidt, A. (1989). Common factors underlying barriers to export: A comparative study in the European and US paper industry. Management International Review, 29(2), 17-32.

Teece, D. J. (1986). Profiting from technological innovation: Implications for integration, collaboration, licensing and public policy. Research Policy, 15(6), 285.

Thomas, D. E., and Eden, L. (2004). What is the shape of the multinationalityperformance relationship? Multinational Business Review, 12(1), 89-110.

Thompson, V. A. (1965). Bureaucracy and innovation. Administrative Science Quarterly, $10,1-20$.

Tolbert, P. S., and Zucker, L. G. (1996). The Institutionalization of Institutional Theory. In S. R. Clegg, C. Hardy, and Nord, W.R. (Eds.) Handbook of Organization Studies. Thousand Oaks, CA: Sage Publications.

Turban, D. B., and Cable, D. M. (2003). Firm reputation and applicant pool characteristics. Journal of Organizational Behavior, 24(6), 733-751.

Tushman, M., and Nadler, D. (1986). Organizing for innovation. California Management Review, 28(3), 74-92.

Verbeke, A., and Li, L. (2009). Toward more effective research on the multinationalityperformance relationship. Management International Review, 49(2), 149-161.

Vernon, R. (1971). Sovereignty at bay: The multinational spread of US enterprises. The International Executive, 13(4), 1-3. 
Vissa, B., and Chacar, A. S. (2009). Leveraging ties: The contingent value of entrepreneurial teams' external advice networks on Indian software venture performance. Strategic Management Journal, 30(11), 1179.

Wernerfelt, B. (1984). A resource-based view of the firm. Strategic Management Journal, 5(2), 171-180.

Wernerfelt, B. B. (1984). A resource-based view of the firm. Strategic Management Journal, 5(2), 171-180.

Williams, R. J., Schnake, M. E., and Fredenberger, W. (2005). The impact of corporate strategy on a firm's reputation. Corporate Reputation Review, 8(3), 187-197.

Williamson, O. E. (1975). Markets and hierarchies: Analysis and Antitrust Implications. New York: The Free Press.

Williamson, O. E. (1981). The economics of organization: The transaction cost approach. American Journal of Sociology, 87(3), 548-577.

Zaheer, S. (1995). Overcoming the liability of foreignness. Academy of Management Journal, 38(2), 341-363.

Zucker, L. G. (1987). Institutional theories of organization. Annual Review of Sociology, $13,443-464$. 
VITA

\section{MARCELO J. ALVARADO-VARGAS}

$1999-2002$

2003-2004

2005-2006

2007-2008

2008-2013
B.Sc., Production Engineering Universidad Privada Boliviana

Cochabamba, Bolivia

Master in International Business

Florida International University

Miami, Florida

Master in Operations and Technology Management Universiteit Gent

Gent, Belgium

Doctoral Candidate in Industrial and Systems Engineering Florida International University

Miami, Florida

Doctoral Candidate in Business Administration

Florida International University

Miami, Florida

\section{PUBLICATIONS AND PRESENTATIONS}

Kelley, K.J., and Alvarado-Vargas, M.J. (forthcoming). Information management technologies, service characteristics, and long-term performance: Exploring the mediating role of firm reputation in the production paradox. The Service Industries Journal.

Alvarado-Vargas, M.J., and Kelley, K.J. (forthcoming). Online signaling environment and brand valuation in banks. Managing Service Quality.

Alvarado-Vargas, M.J. (2008). The technological innovation adoption race: Things you must know to finish it in first places. The Business Review, Cambridge, 11(2):76.

Coulier, C. and Alvarado-Vargas, M.J. (2006). "Modeling and Simulating of Operating Room Scheduling", Ghent University, College of Economics and Business

Administration, Department of Information Science and Operations Management. Ghent, Belgium.

Alvarado-Vargas, M.J. (2002). "Technical and Experimental Design for Obtaining Vinegar From Pineapple Residuals", Bolivian Private University, College of Engineering and Architecture, Department of Production, Industrial and Systems Engineering. Cochabamba, Bolivia. 
Newburry, W., Alvarado-Vargas, M.J., Borda, A., Ortiz-Baldo, C.M., Duran-Zurita, E., Galli-Geleilate, J.M., Guerra, M., Hermans, M., Lasio-Morello, M.V., Madero, S., Olivas-Lujan, M., and Zwerg-Villegas, A.M. (2013). Perceived career opportunities and benefits from globalization in Latin America. Academy of International Business - Latin America Chapter Annual Conference, Puebla, Mexico.

Kelley, K.J.; Alvarado-Vargas, M.J. and Palacios-Marques, D. (2012). Bullwhip severity in conditions of uncertainty: Regional versus global supply chain strategies. Academy of International Business - Southeast Annual Conference, Ft. Lauderdale, FL.

Alvarado-Vargas, M.J. and Kelley, K. (2012). Bullwhip severity in conditions of uncertainty: Regional versus global supply chain strategies. Strategic Management Society Annual Conference, Prague, Czech Republic.

Newburry, W.; Borda, A.; Alvarado-Vargas, M.J. and Galli-Geleilate, J.M. (2011). Perceived career opportunities from globalization: Globalization capabilities and attitudes towards women in Peru and Brazil. Iberoamerican Academy of Management Conference, Lima, Peru.

Thams, Y.; Alvarado-Vargas, M.J., and Newburry, W. (2011). Multinationality as a predictor of MNC's intangible performance or reputation. Academy of International Business Annual Conference, Nagoya, Japan.

Alvarado-Vargas, M.J. and Kelley, K. (2011). International supply chain strategies in an uncertain world: A bullwhip perspective. Academy of International Business Annual Conference, Nagoya, Japan.

Kelley, K.; Thams, Y.; Alvarado-Vargas, M.J. and Yang, K. (2010). Influence of institutional distance on MNCs' internationalization speed. Strategic Management Society Annual Conference, Rome, Italy.

Alvarado-Vargas, M.J. (2010). The impact of the parent firm's degree of internationalization on its subsidiaries' size: The case of US MNCs. Academy of International Business Annual Conference, Rio de Janeiro, Brazil.

Alvarado-Vargas, M.J. and Kelley, K. (2009). Economic uncertainty, product architecture, and the bullwhip effect: Strategies for coping with supply chain variability. Strategic Management Society Annual Conference, Washington D.C.

Kelley, K, Alvarado-Vargas, M.J., and Thams, Y. (2009). Regionalization and economic growth volatility: An IB perspective on Dreher's 2006 article linking globalization index levels and economic growth. Academy of International Business Annual Conference, San Diego, California. 